\title{
National Register Testing at 41BQ285, Bosque County, Texas: FM 56 Bridge Replacement at the North Bosque River
}

Timothy B. Griffith

Prewitt and Associates, Inc.

Karl W. Kibler

Cross Timbers Geoarcheological Services

Douglas K. Boyd

Prewitt and Associates, Inc.

Follow this and additional works at: https://scholarworks.sfasu.edu/ita

Part of the American Material Culture Commons, Archaeological Anthropology Commons, Environmental Studies Commons, Other American Studies Commons, Other Arts and Humanities Commons, Other History of Art, Architecture, and Archaeology Commons, and the United States History Commons

Tell us how this article helped you.

This Article is brought to you for free and open access by the Center for Regional Heritage Research at SFA ScholarWorks. It has been accepted for inclusion in Index of Texas Archaeology: Open Access Gray Literature from the Lone Star State by an authorized editor of SFA ScholarWorks. For more information, please contact cdsscholarworks@sfasu.edu. 
National Register Testing at 41BQ285, Bosque County, Texas: FM 56 Bridge Replacement at the North Bosque River

\section{Creative Commons License}

\section{c) (1)@ $\Theta$}

This work is licensed under a Creative Commons Attribution-NonCommercial-No Derivative Works 4.0 International License. 
NATIONAL REGISTER TESTING AT 41BQ285, BOSQUE COUNTY, TEXAS: FM 56 BRIDGE REPLACEMENT AT THE NORTH BOSQUE RIVER

\author{
by \\ Timothy B. Griffith \\ Karl W. Kibler \\ and \\ Douglas K. Boyd \\ Principal Investigator: Ross C. Fields \\ with contributions by \\ Brian S. Shaffer \\ Leslie L. Bush \\ Timothy K. Perttula \\ David G. Robinson \\ Jeffrey R. Ferguson \\ Michael D. Glascock \\ and \\ Karen M. Gardner
}

REPORTS OF INVESTIGATIONS, NUMBER 160

Prewitt and Associates, Inc.

Cultural Resources Services

Austin, Texas

PAI Nos. 207017 and 209011

ARCHEOLOGICAL STUDIES PROGRAM, REPORT NO. 101

Texas Department of Transportation

Environmental Affairs Division

Austin, Texas

CSJ No. 0398-01-035

June 2010

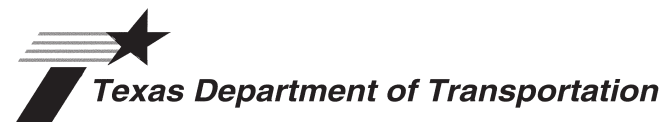

TEXAS ANTIQUITIES PERMIT NO. 4102 


\title{
NATIONAL REGISTER TESTING AT 41BQ285, BOSQUE COUNTY, TEXAS: FM 56 BRIDGE REPLACEMENT AT THE NORTH BOSQUE RIVER
}

\author{
COPYRIGHT @ 2010
}

Texas Department of Transportation (TxDOT)

This is a work for hire produced by the Texas Department of Transportation (TxDOT), which owns all rights, title, and interest in and to all data and other information developed for this project under Contract Nos. 575XXSA006 and 579XXSA002. Brief passages from this publication may be reproduced without permission provided that credit is given to TxDOT and Prewitt and Associates, Inc. Permission to reprint an entire chapter, section, figures, or tables must be obtained in advance from the Supervisor of the Archeological Studies Program, Environmental Affairs Division, Texas Department of Transportation, 125 East 11th Street, Austin, Texas, 78701. Copies of this publication have been deposited with the Texas State Library in compliance with the State Depository Requirement.

jointly published by the

Texas Department of Transportation

Environmental Affairs Division

Archeological Studies Program

Scott Pletka, Ph.D., Supervisor, Archeological Studies Program

Archeological Studies Program, Report No. 101

Al McGraw, Series Editor

and

Prewitt and Associates, Inc.

Cultural Resources Services

Austin, Texas

PAI Project Nos. 207017 and 209011

Reports of Investigations, Number 160

Printed by Morgan Printing in Austin, Texas

ISBN 91-930788-70-3 


\section{TABLE OF CONTENTS}

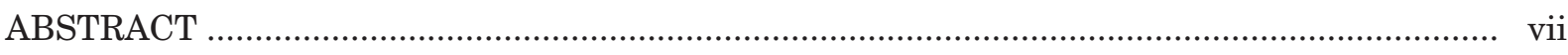

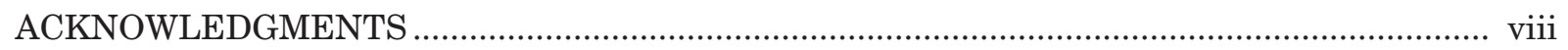

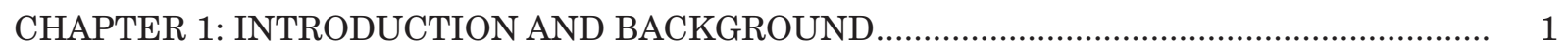

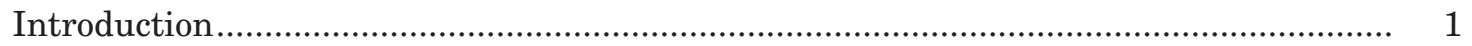

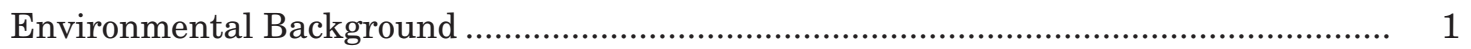

Archeological and Cultural Background ................................................................... 3

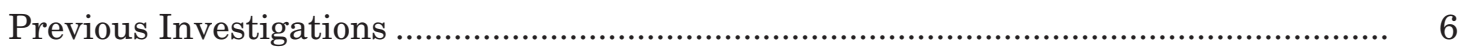

CHAPTER 2: METHODS OF INVESTIGATION AND WORK ACCOMPLISHED .................... 7

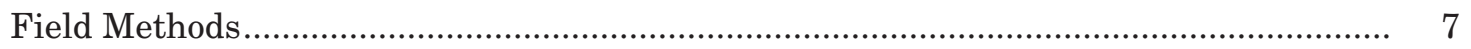

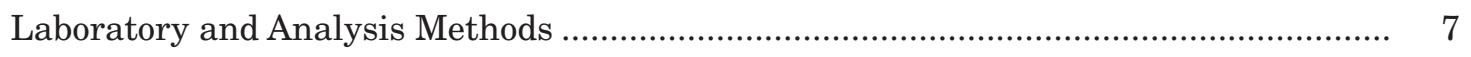

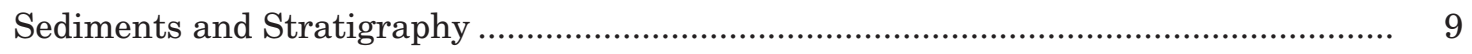

CHAPTER 3: DESCRIPTION OF CULTURAL MATERIALS ................................................ 11

Chipped Stone Tools, Cores, and Lithic Debitage ........................................................ 11

Projectile Points ......................................................................................... 11

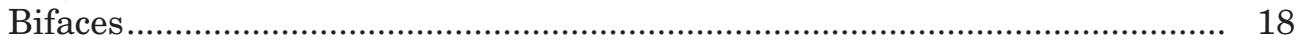

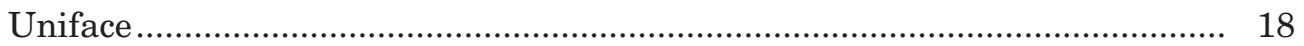

Utilized Flakes ..................................................................................... 18

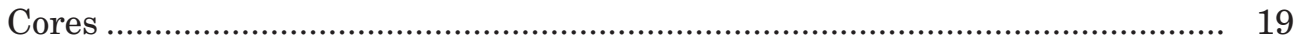

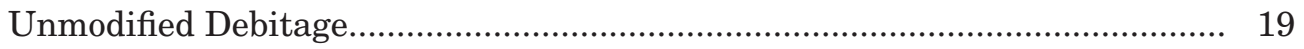

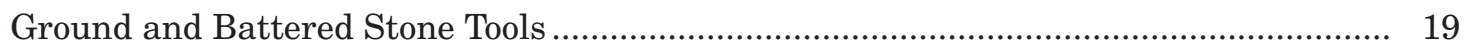

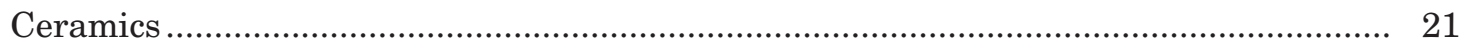

Other Cultural Materials ................................................................................ 21

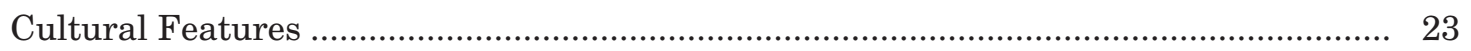

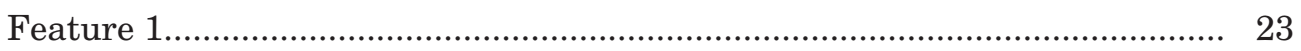

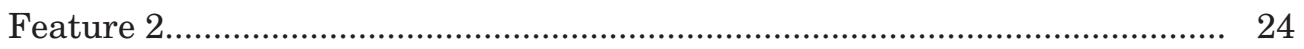

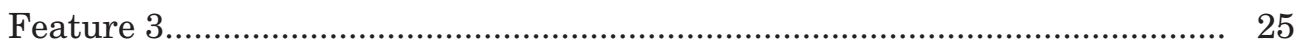

CHAPTER 4: ARTIFACT AND FEATURE DISTRIBUTIONS AND DEFINITION

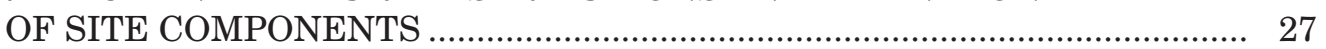

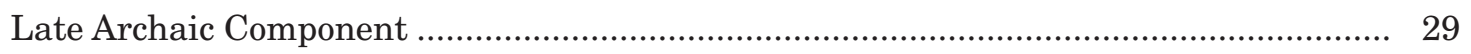

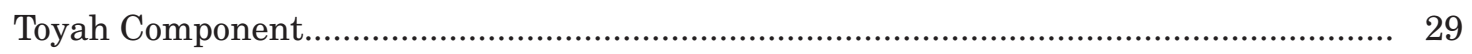

What is the "Toyah" Component at 41BQ285? ......................................................... 35

Is 41BQ285 Classic Toyah?........................................................................ 36

Sociocultural Identity at 41BQ285 ........................................................ 39

CHAPTER 5: SUMMARY AND ASSESSMENT OF 41BQ285 ….............................................. 43

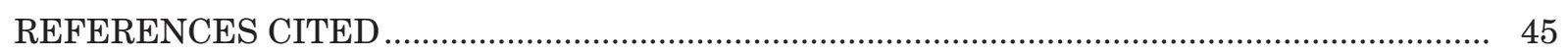

APPENDIX A: Analysis of Vertebrate Remains ..................................................................... 51

Brian S. Shaffer 


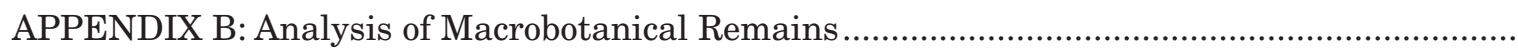

Leslie L. Bush

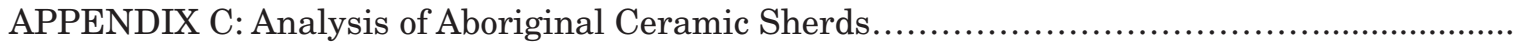

Timothy K. Perttula, David G. Robinson, Jeffrey R. Ferguson, and Michael D. Glascock

APPENDIX D: Analysis of Freshwater Mussel Shells........................................... 105 Karen M. Gardner 


\section{LIST OF FIGURES}

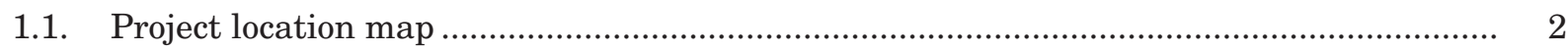

2.1. Map of 41BQ285 showing the locations of backhoe trenches and test units...................... 8

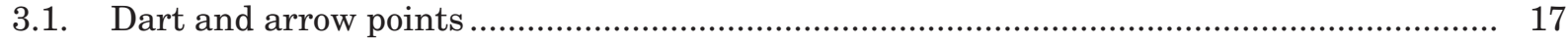

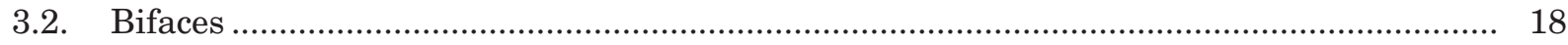

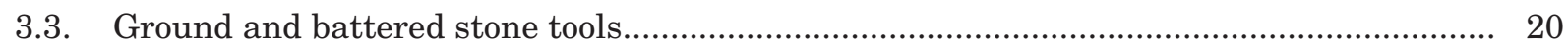

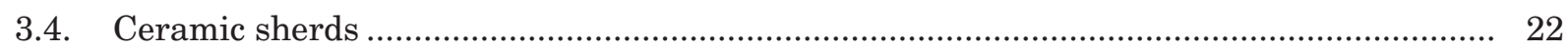

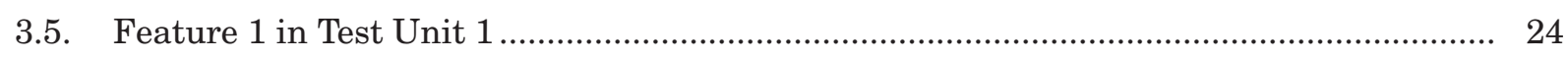

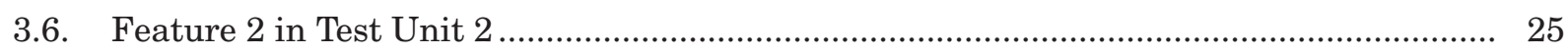

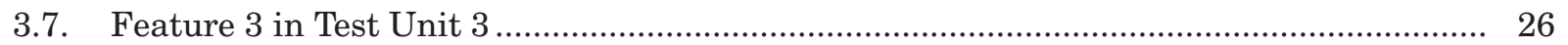

4.1 Vertical distribution of diagnostic artifacts, radiocarbon dates, and other

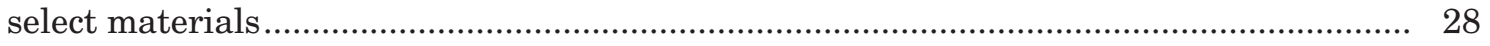

4.2. Location of 41BQ285 in relation to the Classic Toyah area and selected Toyah sites ........ 37

4.3. Map showing location of 41BQ285 relative to Shafer's (2006) proposed northern and southern Prairie Caddo areas and ecological regions in northeast Texas................... 40

C.1. Bivariate plot of chromium and potassium showing the relationship between the main $\mathrm{CT}$ reference groups and the new samples. 


\section{LIST OF TABLES}

3.1. Provenience of cultural materials recovered from 41BQ285 .......................................... 12

3.2. Metric attributes of projectile points from 41BQ285 .................................................... 16

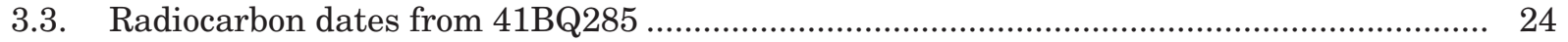

4.1. Cultural materials recovered from 41BQ285 by cultural components ............................. 30

4.2. Summary of cultural components defined at 41BQ285 .................................................. 32

A.1. Number of identified specimens and minimum number of individuals by faunal

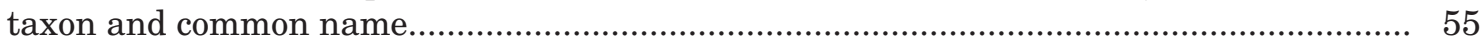

A.2. Faunal taphonomy by provenience ............................................................................... 56

A.3. Number of identified specimens by provenience................................................................. 57

A.4 Faunal remains recovered from 41BQ285 by cultural component and provenience .......... 58

B.1. Analyzed flotation samples and their proveniences ....................................................... 73

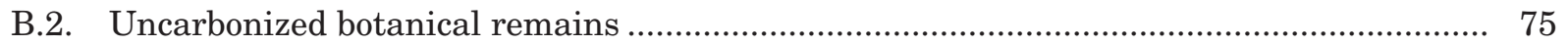

B.3. Carbonized botanical remains (count) .......................................................................... 76

B.4. Carbonized botanical remains (weight in grams) ........................................................ 78

C.1. Aboriginal ceramic sherds from 41BQ285 ............................................................. 87

C.2. Petrographic analysis: point count data percentage.................................................. 90

C.3. Sample IDs used by the University of Missouri Research Reactor ................................. 96

C.4. Probabilities of group membership using a Mahalanobis distance calculation

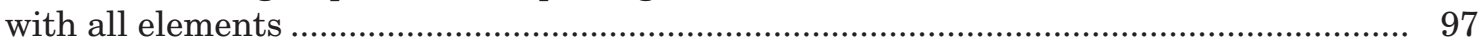

D.1. Provenience and taxa of freshwater mussel shells ......................................................... 108 


\begin{abstract}
Prewitt and Associates, Inc., conducted archeological test excavations at 41BQ285 in June 2006 for the Texas Department of Transportation under Texas Antiquities Permit No. 4102. Site 41BQ285, in southeastern Bosque County, was located during an archeological survey for the proposed replacement of the FM 56 bridge over the North Bosque River. It is a prehistoric campsite buried in a cumulic soil in the upper deposits of a late Holocene alluvial terrace. Mechanical excavations consisted of re-opening four backhoe trenches from the survey phase followed by hand excavation of six 1x1-m test units. This work identified three burned rock features and yielded a moderate amount of materials, including projectile points and bifaces, pottery sherds, unmodified debitage, vertebrate faunal remains, and freshwater mussel shells. Diagnostic artifacts and five radiocarbon ages indicate that the site has a lower but rather ephemeral Late Archaic component and an upper and more substantial Late Prehistoric component.
\end{abstract}

The Late Prehistoric component yielded Perdiz arrow points and ceramics, and it is radiocarbon dated to between A.D. 1280 and 1650. The evidence suggests a series of relatively short occupations and a focus on the use of local resources. Site activities included late-stage biface reduction and bifacial tool production, tool resharpening, and the exploitation and intensive processing of deer. Foodstuffs were processed and prepared using bifacial tools, ground and battered stone tools, rock-lined cooking basins, and small ceramic jars and bowls.

The Late Prehistoric component is Toyah-like in many ways, but the small sample size and nature of the materials preclude assigning it a specific sociocultural group or archeological phase. Of particular interest are the five pottery sherds - two plain, two fingernail punctate, and one engraved sherd from a carinated bowl with a Caddo-like design. Geochemical analysis indicates that none of the pottery, including the engraved bowl sherd, matches any Caddo-made pottery from East Texas. The fact that a Caddo vessel form and decorative style appears on pottery that was probably made in or near Bosque County is interesting and adds a new dynamic to our understanding of the Toyah phenomenon in central Texas.

The portion of site 41BQ285 within FM 56 is considered eligible for listing in the National Register of Historic Places (NRHP) or for designation as a State Archeological Landmark (SAL). However, current investigations already recovered most of the Late Prehistoric component within the spatially limited project area, and additional investigations inside the highway right of way cannot reasonably be expected to contribute any more significant archeological information. Therefore, no further fieldwork is recommended, and construction should be allowed to proceed.

\title{
CURATION
}

All project records and artifacts generated by this project will be submitted for permanent curation at the Texas Archeological Research Laboratory at The University of Texas at Austin. 


\section{ACKNOWLEDGMENTS}

Fieldwork for this project was conducted under the supervision of Timothy Griffith, who served as project archeologist. The field crew consisted of Rob Thrift, Beth Sain, Daniel Teague, and Carolyn Keagle. Karl Kibler served as project geomorphologist, and Ross Fields served as principal investigator.

Texas Department of Transportation personnel who helped oversee the successful completion of this project include Environmental Affairs Division archeologists Jon Budd, Jim Abbott, and John Arnn and Waco District personnel David Jayroe and Keri Brown.

Rob Thrift completed the laboratory processing and cataloging of artifacts under the supervision of Karen Gardner.

A number of other individuals served as analysts or consultants during the analysis phase of this project. They include Dr. Brian Shaffer (vertebrate faunal analysis); Dr. Leslie Bush (macrobotanical analysis); Dr. Timothy Perttula, Dr. David Robinson, Dr. Jeffrey Ferguson, and Dr. Michael Glascock (ceramic analysis); Karen Gardner (freshwater mussel shell analysis); and Cory Broehm, who examined the human tooth recovered from the site.

This report was written by Griffith, Kibler, and Doug Boyd with contributions from Shaffer (Appendix A); Bush (Appendix B); Perttula, Robinson, Ferguson, and Glascock (Appendix C); and Gardner (Appendix D). Report production was handled by Elaine Robbins, Sandra Hannum, and Brian Wootan. 


\section{INTRODUCTION AND BACKGROUND}

\section{INTRODUCTION}

Archeological test excavations at 41BQ285 were conducted by Prewitt and Associates, Inc. (PAI), for the Texas Department of Transportation (TxDOT), Environmental Affairs Division, under Contract No. 575XXSA006 (Work Authorization No. 57537SA006) and Texas Antiquities Permit No. 4102 from the Texas Historical Commission. Fieldwork was initiated on June 5, 2006, and concluded June 16, 2006. Laboratory processing and interim report preparation took place in July and August 2006. The development of an analysis plan and subsequent artifact analysis and reporting was conducted under Work Authorization No. 57905SA002. The work was done to assist TxDOT to comply with Section 106 of the National Historic Preservation Act and the Antiquities Code of Texas.

Site 41BQ285 is in southeastern Bosque County within the city limits of Valley Mills, Texas, approximately $30 \mathrm{~km}$ west of Waco, where FM 56 crosses the North Bosque River (Figure 1.1). The site sits at an elevation of ca. 550-575 ft above sea level on an alluvial flood terrace along the north bank of the river. The current archeological investigations were prompted by a plan to replace the FM 56 bridge over the river, which would directly impact 41BQ285.

West of the existing FM 56 bridge right of way, a portion of 41BQ285 extends into new right of way needed for the proposed replacement of the bridge. Much of the existing FM 56 right of way is occupied by a 4-m-thick fill section and has been disturbed by previous road and bridge construction. Archeological investigations were restricted to the part of the site within the narrow new right of way, but the site may extend beyond the new right of way outside the current project area. As described below, 41BQ285 is a prehistoric site buried in Holocene alluvium. Archeological test excavations resulted in the recovery of a moderate amount of artifacts and identification of features that are assigned to two different cultural components.

\section{ENVIRONMENTAL BACKGROUND}

Bosque County lies within the Grand Prairie, a large natural region or geomorphic province in north-central Texas that extends south from the Red River to the Llano Uplift and northern end of the Balcones Canyonlands in central Texas. From its eastern boundary to its western reaches, the Grand Prairie landscape rises over $1,000 \mathrm{ft}(305 \mathrm{~m})$ in elevation. The Grand Prairie varies in size and composition depending on how it is defined. Hill (1901) subdivided the province into three subprovinces: the Fort Worth Prairie, the Lampasas Cut Plain, and the Western Cross Timbers. Hayward et al. (1996) later modified these geomorphic subdivisions by renaming the southern portion of Hill's Fort Worth Prairie the Washita Prairie (due to the north-to-south outcrop gradation from Duck Creek and Fort Worth to the Washita limestones), and by separating landscapes formed on the Glen Rose limestone (Glen Rose Prairie) from the Lampasas Cut Plain. In total, Hayward et al. (1996) recognize four subprovinces of the Grand Prairie that are due to different underlying lithological units: the Washita Prairie, Glen Rose Prairie, Lampasas Cut Plain, and Western Cross Timbers.

From an ecological point of view, particularly regarding floral communities, the Grand Prairie is viewed much differently. Diamond et al. (1987) exclude the Lampasas Cut Plain from their version of the Grand Prairie, viewing it as part of the Blackland Prairie. On the other hand, Diggs et al. (1999) divide the Grand 
FIGURE REDACTED

Figure 1.1. Project location map. 
Prairie into northern (Fort Worth Prairie) and southern (Lampasas Cut Plain) segments that are wedged between the wooded landscape of the Western Cross Timbers to the west and the Eastern Cross Timbers and Blackland Prairie to the east.

The soils of Bosque County typically consist of mollisols and inceptisols. Upland soils are generally thin, stony, and clayey or loamy and belong to the Eckrant-Brackett-Cranfill soil association, while soils on stream terraces and floodplains are generally deep and loamy and belong to the Frio-Bosque soil association (Stringer 1980).

The Grand Prairie has a subtropical climate with dry winters and hot, humid summers (Natural Fibers Information Center 1987:6). The continental climatic characteristics dominate the weather patterns, with large daily and annual temperature ranges and wide annual fluctuations in rainfall. The rainfall pattern is bimodal, with peaks in the late spring and early fall. Annual rainfall totals decrease across the region from east to west. The average annual rainfall for the Bosque County is 32.95 inches (Stringer 1980:64).

Summers are hot and humid with little variation in conditions from day to day (Natural Fibers Information Center 1987:7). Most days reach the $90^{\circ} \mathrm{F}$ mark or higher, and $100+^{\circ} \mathrm{F}$ readings are not uncommon in July and August. Daily highs may be slightly less in the southern portion of the region due to increased relative humidity. Winters are relatively mild but are punctuated by occasional outbreaks of arctic air masses (northers) that can drastically drop temperatures over a few hours (Natural Fibers Information Center 1987:6). These colder conditions are usually short-lived as warmer southerly winds soon return.

\section{ARCHEOLOGICAL AND CULTURAL BACKGROUND}

Paleoindian (11,500-8800 в.P.) occupations of the central Texas region are represented by surficial and deeply buried sites, rockshelter sites, and isolated artifacts. The period is often described as having been characterized by small but highly mobile bands of foragers who were specialized hunters of Pleistocene megafauna. However, a more accurate view of Paleoindian lifeways probably includes the utilization of a much wider array of resources. Recent investigations at the Wilson-Leonard site (41WM235) support this view and have challenged the fundamental defining criteria of the Paleoindian period, that of artifacts in association with late Pleistocene megafauna (Collins 1998).

Collins (1995) divides the Paleoindian period into early and late subperiods. Two projectile point styles, Clovis and Folsom, are included in the early subperiod. Clovis chipped stone artifact assemblages, including the diagnostic fluted lanceolate Clovis point, were produced by bifacial, flake, and prismatic-blade techniques on high-quality and oftentimes exotic lithic materials (Collins 1990). Along with chipped stone artifacts, Clovis assemblages include engraved stones, bone and ivory points, stone bolas, and ochre (Collins 1995:381; Collins et al. 1992). Clovis, as well as a number of later Paleoindian dart points, have been recovered from the Gault site in Bell County (Collins and Brown 2000) and the Triple S Ranch site in Hamilton County (Hatfield 1997). Probable Clovis polyhedral blade cores have been found in Hamilton County (Goode and Mallouf 1991). Analyses of Clovis artifacts and site types suggest that Clovis peoples were well-adapted, generalized hunter-gatherers with the technology to hunt larger game but not solely rely on it. In contrast, Folsom tool kits, consisting of fluted Folsom points, thin unfluted (Midland) points, large thin bifaces, and end scrapers, are more indicative of specialized hunting, particularly of bison (Collins 1995:382). Folsom points have been recovered from Horn Shelter No. 2 along the Brazos River (Redder 1985; Watt 1978).

Postdating Clovis and Folsom points in the archeological record are a series of dart point styles for which the temporal, technological, or cultural significance is unclear. Several of these styles were recovered from Horn Shelter No. 2 and include Plainview, Scottsbluff, Dalton, and San Patrice (Watt's [1978] Brazos Fishtail points). Often the Plainview type name is given to any unfluted lanceolate dart point; however, Collins (1995:382) has noted that many of these points typed as Plainview do not parallel Plainview type-site points in thinness and flaking technology. Also problematic are the chronological position and cultural significance of Dalton and San Patrice dart points. Components and artifact and feature assemblages of the later Paleoindian subperiod appear to be Archaic-like 
in nature and in many ways may represent a transition between the early Paleoindian and succeeding Archaic periods (Collins 1995:382).

The Archaic period for central Texas dates from ca. 8800 to 1300-1200 B.P. (Collins 1995). The Archaic period is generally believed to represent a shift toward the hunting and gathering of a wider array of animal and plant resources and a decrease in group mobility (Willey and Phillips 1958:107-108). In the eastern and southwestern U.S. and on the Great Plains, the Archaic period is succeeded by the development of horticulturalbased, semisedentary to sedentary societies. In these areas the Archaic truly represents a developmental stage of adaptation as Willey and Phillips (1958) define it. For central Texas, this notion of the Archaic is somewhat problematic. The evidence suggests that Archaic-like adaptations were in place prior to the Archaic (see Collins 1995:381-382; Collins 1998; Collins et al. 1990) and that these practices continued into the succeeding Late Prehistoric period (Collins 1995:385; Prewitt 1981:74). In this sense, the Archaic period of central Texas is not a developmental stage but an arbitrary chronological construct and projectile point style sequence. The establishment of this sequence is based on several decades of archeological investigations at stratified Archaic sites along the eastern and southern margins of the Edwards Plateau. Collins (1995) and Johnson and Goode (1994) have divided this sequence into three parts-early, middle, and late-based on perceived (though not fully agreed upon by all scholars) technological, environmental, and adaptive changes.

Early Archaic (8800-6000 B.P.) sites are small and their tool assemblages are very diverse (Weir 1976:115-122), suggesting that populations were highly mobile and densities low (Prewitt 1985:217). Early Archaic sites are concentrated along the eastern and southern margins of the Edwards Plateau (Johnson and Goode 1994; McKinney 1981). This distribution may be indicative of climatic conditions at the time, given that these environments have many more reliable water sources and a diverse resource base. Early Archaic projectile point styles include Angostura, Gower, Wells, Martindale, and Uvalde. Manos, metates, hammerstones, Clear Fork and Guadalupe bifaces, and a variety of other bifacial and unifacial tools are common to Early Archaic assemblages. The construction and use of rock hearths and ovens reflect a specialized subsistence strategy (exploitation of roots and bulbs?) during the Early Archaic. These burned rock features most likely represent the technological predecessors of the larger burned rock middens that developed extensively later in the Archaic period (Collins 1995:383). Significant Early Archaic sites include the Youngsport site in Bell County (Shafer 1963), which yielded Gower and Wells dart points from deeply buried contexts.

During the Middle Archaic period (60004000 B.P.), the number and distribution of sites, as well as site size, increased due to probable increases in population densities (Prewitt 1981:73; Weir 1976:124, 135). Macrobands may have formed at least seasonally, or an increased number of small groups may have utilized the same sites for longer periods of time (Weir 1976:130-131). A greater reliance on plant foods is suggested by the presence of burned rock middens toward the end of the Middle Archaic, although tool kits still imply a strong reliance on hunting (Prewitt 1985:222-226). Middle Archaic projectile point styles include Bell, Andice, Taylor, Baird, Nolan, and Travis. Bell and Andice points reflect a shift in lithic technology from the preceding Early Archaic Martindale and Uvalde point styles (Collins 1995:384). Johnson and Goode (1994:25) suggest that the Bell and Andice darts were parts of a specialized bison-hunting tool kit. They also suggest that the beginning of the Middle Archaic was marked by an influx of bison and bison-hunting groups from the Eastern Woodland margins during a slightly more mesic period. Bell points and bison remains were recovered from the Landslide site in Bell County (Sorrow et al. 1967). Bison disappeared, or were reduced in number, as xeric conditions prevailed during the latter half of the Middle Archaic. Later Middle Archaic projectile point styles represent another shift in lithic technology (Collins 1995:384; Johnson and Goode 1994:27). Prewitt (personal communication 2000) postulates that the production and morphology of Travis and Nolan points are similar to projectile points from the Lower Pecos region. Such characteristics as beveled stems and overall morphology may have originated in the Lower Pecos, since these elements appeared earlier there than they did in central Texas. Shafer's (1963:67) surprise that Nolan points, which are more common in sites to the south and west, were not found in greater numbers at the Youngsport site might 
support the idea that bearers of these darts came out of the Lower Pecos and moved into adjacent portions of central Texas, but did not utilize all portions of central Texas equally. This interval also saw a shift to more xeric conditions and the development of burned rock middens, the masses of burned rocks left over from multiple episodes of baking and cooking with hot rock hearths and ovens. Johnson and Goode (1994:26) believe that the dry conditions promoted the spread of xerophytic plants, such as yucca and sotol, and that these plants were collected and cooked in large rock ovens by late Middle Archaic peoples.

During the succeeding Late Archaic period (4000 to 1300-1200 B.P.), populations continued to increase (Prewitt 1985:217). Within stratified Archaic sites, such as Youngsport and Landslide, the Britton, Higginbotham, and McMillan sites in McLennan County (Story and Shafer 1965, Mehalchick and Kibler 2008), and the Steele site in Hill County (Stephenson 1970), the Late Archaic components contain the densest concentrations of cultural materials. The establishment of large cemeteries along drainages suggests strong territorial ties by certain groups (Story 1985:40). A variety of projectile point styles appeared throughout the Late Archaic period. Johnson and Goode (1994:29-35) divide the Late Archaic into two parts, Late Archaic I and Late Archaic II, based on increased population densities and perceived evidence of Eastern Woodland ceremonial rituals and religious ideological influences. Middle Archaic subsistence technology, including the development of burned rock middens, continued into the Late Archaic period. Collins (1995:384) states that, at the beginning of the Late Archaic period, the construction and use of burned rock middens reached its zenith and that their use declined during the latter half of the Late Archaic. However, there is mounting data that midden formation and use culminated much later and that this high level of use continued into the early Late Prehistoric period (Black et al. 1997:270-284; Kleinbach et al. 1995:795). A picture of prevalent burned rock midden development in the eastern part the central Texas region after 2000 B.P. is becoming clear. This parallels the widely recognized occurrence of post-2000 B.P. middens in the western reaches of the Edwards Plateau (see Goode
1991). The use of rock hearths and ovens, resulting in the development of burned rock middens, appears to have been a major part of the subsistence strategy as a decrease in the importance of hunting, inferred from the low ratio of projectile points to other tools in site assemblages, may have occurred (Prewitt 1981:74).

The Late Prehistoric period (1300-1200 to 300 в.P.) is marked by the introduction of the bow and arrow and, later, ceramics into central Texas. Population densities dropped considerably from their Late Archaic peak (Prewitt 1985:217). Subsistence strategies did not differ greatly from the preceding period, although bison became an important economic resource during the later part of the Late Prehistoric period (Prewitt 1981:74). The use of rock hearths and ovens for plant food processing and the resulting development of burned rock middens continued throughout the Late Prehistoric period (Black et al. 1997; Kleinbach et al. 1995:795). Horticulture came into play very late in the region but was of minor importance to overall subsistence strategies (Collins 1995:385).

In central Texas the Late Prehistoric period is generally associated with the Austin and Toyah phases (Jelks 1962; Prewitt 1981:82-84). Story (1990:364), in her overview of the middle Brazos River basin, argues for a period/horizon characterized by Alba points and Early Caddoan-like pottery intermediate between the Austin and Toyah phases. Evidence of this proposed archeological manifestation was found at the Chupik site in McLennan County (Watt 1953). Much of what we know about the Austin and Toyah phases comes from rockshelter sites in and around Lake Whitney in Bosque and Hill Counties (see Jelks 1962; Stephenson 1970). Austin and Toyah phase horizon markers, Scallorn-Edwards and Perdiz arrow points, respectively, are distributed across most of the state. The introduction of Scallorn and Edwards arrow points into central Texas was often marked by evidence of violence and conflict, as many excavated burials contain these point tips in contexts indicating that they were the cause of death (Prewitt 1981:83). Subsistence strategies and technologies (other than arrow points) did not change much from the preceding Late Archaic. This continuity is recognized by Prewitt's (1981) use of the term "Neoarchaic." In fact, Johnson and Goode (1994:39-40) and Collins (1995:385) 
state that the break between the Late Archaic and the Late Prehistoric could be appropriately represented by the break between the Austin and Toyah phases.

Around $1000-750$ B.P., slightly more xeric or drought-prone climatic conditions returned to the region, and bison returned in large numbers (Huebner 1991; Toomey et al. 1993). Utilizing this vast resource, Toyah phase peoples were equipped with Perdiz point-tipped arrows, end scrapers, four-beveled-edge knives, and plain bone-tempered ceramics. The technology and subsistence strategies of the Toyah phase represent a completely different tradition than the preceding Austin phase. Contact with Caddoan groups to the east and northeast is represented by the presence of Caddoan ceramics in site assemblages, particularly in the eastern peripheral areas of central Texas (e.g., Stephenson 1970). Collins (1995:388) states that burned rock middens fell out of use as bison hunting and group mobility obtained a level of importance not witnessed since Folsom times. While the importance of bison hunting and high group mobility can hardly be disputed, the cessation of burned rock midden development during the Toyah phase is tenuous. An examination of Toyah-age radiocarbon assays and assemblages by Black et al. (1997) suggests that their association with burned rock middens represents more than a "thin veneer" capping Archaic-age features. Black et al. (1997) claim that rock hearth and oven use resulting in burned rock middens, while not as prevalent as in earlier periods, played a role in the adaptive strategies of Toyah peoples.

\section{PREVIOUS INVESTIGATIONS}

Personnel from Prewitt and Associates, Inc., recorded 41BQ285 during trenching in an intensive survey of new right of way for the FM 56 bridge replacement over the North Bosque River in 2005 (Griffith 2005). The site was recorded as a dense accumulation of cultural materials between 28 and $60 \mathrm{~cm}$ below the ground surface and a light scatter of cultural materials between 60 and $80 \mathrm{~cm}$. Cultural materials consisting of burned rocks, mussel shells, bones, debitage, and pieces of charcoal were recorded. An intact hearth feature containing burned rocks, bones, and pieces of charcoal was found in Backhoe Trench 12 and suggested that the site contained undisturbed deposits. The site was recommended for testing to determine whether it contained important information and hence was eligible for listing in the National Register of Historic Places and designation as a State Archeological Landmark. 


\section{METHODS OF INVESTIGATION AND WORK ACCOMPLISHED}

\section{FIELD METHODS}

Archeological test excavations at 41BQ285 were restricted to the new right of way, a 4-6-mwide corridor on the western side of FM 56 . The investigations consisted of re-locating and re-excavating Trenches 5-7 and 12 from the 2005 survey (Figure 2.1). Six 1x1-m units were then excavated to $100-120 \mathrm{~cm}$ below the ground surface. All test units were excavated in $10-\mathrm{cm}$ levels, and the volume of sediment manually excavated and screened totaled $6.4 \mathrm{~m}^{3}$.

The recovery of a single human molar in Level $1(0-10 \mathrm{~cm})$ of Test Unit 3 prompted the widening of the test unit $30 \mathrm{~cm}$ north and south. These add-on units, designated $3 \mathrm{~A}$ and $3 \mathrm{~B}$, were then excavated down $30 \mathrm{~cm}$ in a search for additional human remains and evidence of a burial pit. At $40 \mathrm{~cm}$ below surface, Test Unit 5 also was extended $30 \mathrm{~cm}$ to the north to more fully investigate an accumulation of mussel shells. This add-on unit, designated Test Unit $5 \mathrm{~A}$, consisted of two levels $(40-60 \mathrm{~cm}$ below surface). Some modern items (bottle glass and plastic fragments) were found in the Test Unit 5 A excavation, but most of the mussel shell lens was intact. Some evidence of disturbance was observed in the upper levels of Test Unit 5 (0$20 \mathrm{~cm})$ and in Test Unit 5A $(40-60 \mathrm{~cm})$ because these units were located adjacent to the FM 56 borrow ditch. It is likely that modern trash discarded along the roadway was introduced into these deposits through bioturbation and mechanical maintenance of the borrow ditch.

Placement of all units was predicated on the presence of cultural materials and possible features observed in various trench profiles. All units were placed beside backhoe trenches in areas deemed best for sampling cultural deposits. Test Unit 1 was placed near the south end of Trench 12 on the west wall to investigate the southern extent of the site. Test Unit 2 was placed on the western side of Trench 5 where a cluster of burned rocks had been observed in the trench wall. Test Unit 3 was placed near the center of Trench 6 on the east side also to investigate an area of burned rocks. Test Unit 4 was placed near the center of Trench 7 on the east side, and Test Unit 6 was placed on the west side to investigate the northern extent of the site. Test Unit 5 was placed on Trench 5 across from Test Unit 2 to investigate an area of burned rocks and mussel shells.

Excavation of each test unit was terminated at 100 to $120 \mathrm{~cm}$ below the ground surface. Soil stratigraphy was recorded and described for all trenches and test units. Site mapping was conducted using a Total Data Station mapping instrument set at an arbitrary elevation of $100.00 \mathrm{~m}$.

Cultural materials recovered from $1 / 4$-inch screening were bagged in the field and then returned to the laboratory. All relevant provenience data was labeled on each bag before it left the field. Artifact counts by test unit and level were recorded in the field to assist in tracking artifact frequencies and distributions across the site. Bones were counted and collected, as were mussel shells, daub, and burned clay. Burned rocks were counted, sorted by size, and weighed in the field but not collected. All Rabdotus sp. shells were counted but not collected. All numbered features were recorded using a standard feature form. Flotation samples were taken from cultural features and nonfeature contexts. All flotation samples were labeled with the relevant provenience data.

\section{LABORATORY AND ANALYSIS METHODS}

Lab processing took place in June 2006 and entailed washing, identifying, and cataloging all 


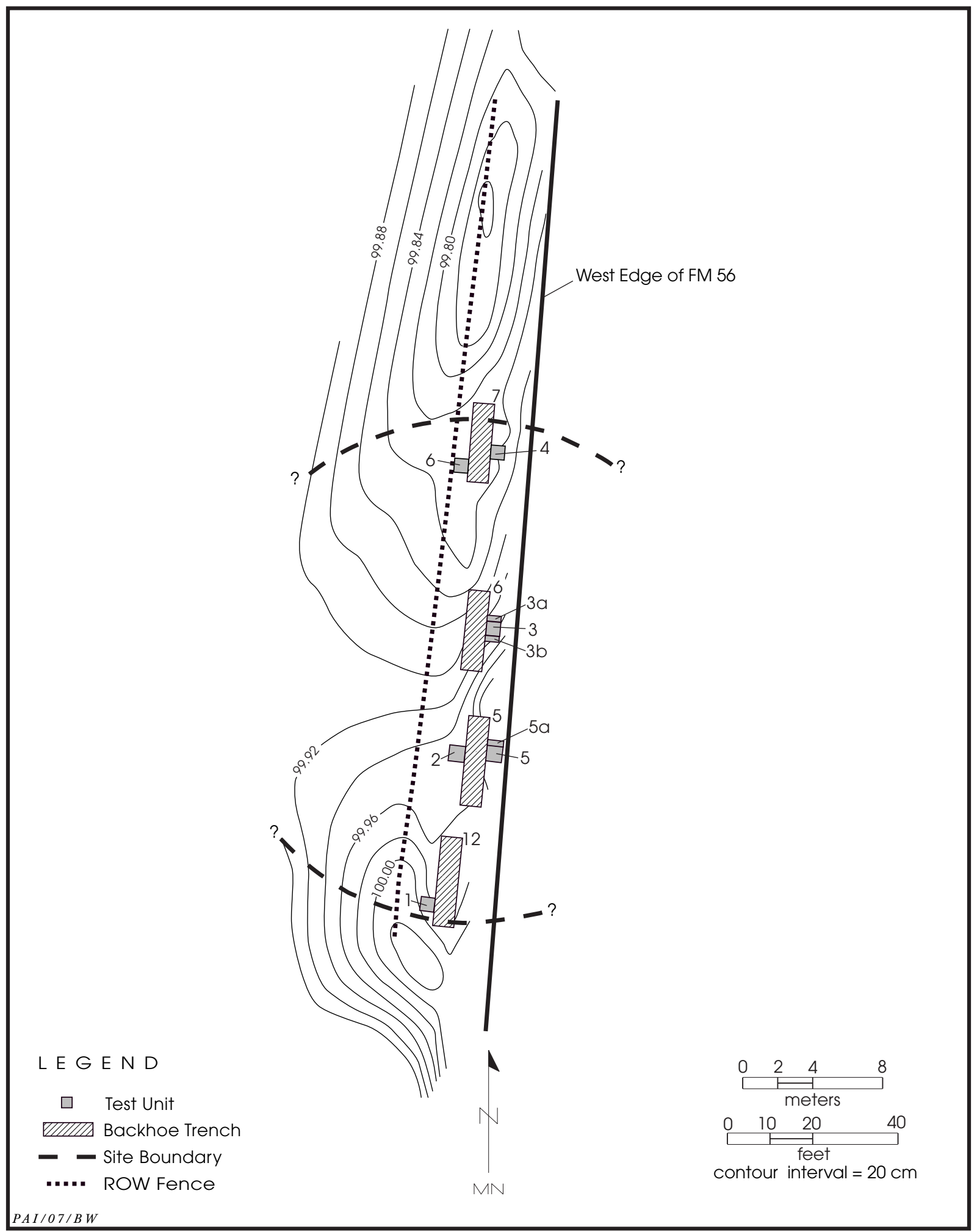

Figure 2.1. Map of 41BQ285 showing the locations of backhoe trenches and test units. 
cultural materials recovered. Artifact identification was limited to classifying materials by technological and functional groups.

Due to the small number of formal and informal chipped and ground and battered stone tools and cores recovered, each is individually described in this report. The descriptions focus on technological category, completeness, raw material type, metrics and, to a limited extent, tool function.

Analysis of the unmodified debitage consisted of a streamlined approach emphasizing flake type, dorsal cortex presence and type, size, and thermal alteration rather than a detailed metric and technological analysis. These attributes are commonly key to interpretations of lithic technology, stone tool manufacture, and reduction strategies (see Andrefsky 2000:23-29). Flake types consist of complete flakes, proximal flake fragments, chips, and chunks. Complete flakes exhibit striking platforms and hinged or feathered terminations. Proximal flake fragments have striking platforms but lack hinged or feathered terminations. Chips are medial or distal flake fragments without striking platforms, and chunks are angular debris that lack flake attributes altogether. The amount and type of cortex present on a flake can provide information on the raw material source, methods used in obtaining raw material, and reduction strategies. Cortex presence was recorded as $0,1-25$, 26-50, 51-75, 76-99, or 100 percent. Where possible, cortex characteristics such as streamworn and abraded or weathered and chalky were recorded. The former attributes (streamworn and abraded) are more characteristic of raw materials procured from secondary sources, such as gravel bars, whereas the latter are more characteristic of raw materials procured from primary sources, e.g., chert nodules that have locally weathered out of the bedrock. Debitage analysis also included the recording of size for complete flakes and flake fragments using seven size classes (1-10, 11-20, 21-30, 31-40, 41-50, 51-60, and 61-70 $\mathrm{mm}$ ).

Sherd type, exterior and interior surface treatment, visible or macroscopic temper, firing conditions, and decorative characteristics and attributes were noted or described for all the ceramic sherds. Metric attributes were recorded and the identification of vessel types was attempted for each sherd. Although some of the sherds display decorative motifs and stylistic attributes typical of some Caddo pottery types, typological identifications were not attempted. Petrographic and instrumental neutron activation analyses were conducted for each sherd, providing more detailed information about the possible origins and manufacture of the vessels represented by the sherd assemblage (see Appendix C).

Numerous vertebrate faunal remains were recovered from 41BQ285. These materials were sent to Dr. Brian Shaffer of the Dallas Historical Society for identification of taxa and taphonomy (see Appendix A). Freshwater mussel shells also were recovered from 41BQ285. Karen Gardner identified the species or genera of each valve or hinge (see Appendix D). The presence or absence of burning was also noted.

Sediment or flotation samples were collected from cultural features and select nonfeature contexts. These samples were processed using a Flote-Tech flotation system, which produced light and heavy fractions. The light-fraction recovery from the feature samples was sent to Dr. Leslie Bush for analysis and identification of charred botanical remains (see Appendix B). The heavyfraction recovery from both feature and nonfeature contexts was checked for cultural materials. All cultural materials found in these flotation samples were counted, but only the vertebrate faunal remains and the freshwater mussel shells were subjected to more detailed analyses.

\section{SEDIMENTS AND STRATIGRAPHY}

The profiles of all test units and backhoe trenches were examined, and the profiles of Test Units 1 and 3 were described in detail. The profile in Test Unit 1 was $120 \mathrm{~cm}$ thick and exhibited an AC-Ab-Bwb soil. The AC horizon (0-41 cm) represents recent flood alluvium and consists of dark grayish brown (10YR 4/2) silty clay loam. It displays a moderate medium granular structure and an abrupt smooth lower boundary. The $\mathrm{Ab}$ horizon (41-84 cm) is a cumulic soil consisting of very dark grayish brown (10YR 3/2) clay loam. It has a weak medium prismatic structure that breaks to moderate medium blocky angular structure and gradual smooth lower boundary. Burned rocks, mussel shell fragments, and Rabdotus sp. shells were observed throughout the Ab horizon. The underlying Bwb horizon (84-120+ cm) is dark grayish brown (10YR 4/2) to grayish brown (10YR $5 / 2$ ) clay loam. It also displays a weak medium 
prismatic structure that breaks to moderate medium blocky angular structure. Very faint carbonate filaments (5 percent) are present, but they are not visible when wet.

The profile of Test Unit 3 was $100 \mathrm{~cm}$ thick and exhibited an AC-Ab-Bwb soil. The AC horizon $(0-22 \mathrm{~cm})$ is recent flood alluvium that consists of dark grayish brown (10YR 4/2) silty clay loam. It has a moderate medium granular structure and clear smooth lower boundary. The Ab horizon (22-64 cm) is dark gray (10YR 4/1) clay loam. It displays a weak medium prismatic structure that breaks to a moderate medium blocky angular structure. Very faint carbonate filaments (2 percent) were present, but they are not visible when wet. The Bwb horizon $(64-100+\mathrm{cm})$ is grayish brown (10YR 5/2) to dark grayish brown (10YR 4/2) clay loam. It also displays a weak medium prismatic structure that breaks to a moderate medium blocky angular structure and faint carbonate filaments (5 percent) that are not visible when wet. A similar AC-Ab-Bwb soil profile was observed in Test Unit 2.
The soil stratigraphy at 41BQ285 reveals that the cultural occupations took place as the North Bosque floodplain stabilized and pedogenesis commenced. It appears that sedimentation continued at a quick enough pace to result in the formation of a cumulic soil and some vertical separation of artifacts and features. This soil is present at similar stratigraphic and geomorphic positions throughout the North Bosque valley, representing a valley-wide stabilization of the floodplain around 2,000 to 1,500 years ago. At several localities 15 to $18 \mathrm{~km}$ downstream at the upper end of Waco Lake, bulk humates from the soil yielded radiocarbon ages of $690 \pm 70$ to $1720 \pm 60$ B.P. (Mehalchick and Kibler 2008:288; Scott et al. 2002), indicating that the soil is time transgressive across the valley. At 41BQ285 and other sites, the soil is buried due to topping of terrace surface by recent floodwaters. The mantle of recent sediments, which is up to 41 $\mathrm{cm}$ thick at 41BQ285, thickens downstream to nearly $1 \mathrm{~m}$ at the upper end of Waco Lake, the result of base level changes and back flooding since the construction of the lake. 


\section{DESCRIPTION OF CULTURAL MATERIALS}

Cultural materials recovered from 41BQ285 during test excavations consist of chipped stone tools, cores, lithic debitage, ground and battered stone tools, ceramics, vertebrate faunal remains, freshwater mussel shells, burned rocks, and burned clay. Table 3.1 lists all of the recovered cultural materials by provenience.

\section{CHIPPED STONE TOOLS, CORES, AND LITHIC DEBITAGE}

Chipped stone artifacts are the most abundant artifact type recovered. The assemblage consists of 5 arrow points, 2 dart points, 21 bifaces, 1 uniface, 5 utilized flakes, 6 cores, and 2,106 pieces of unmodified debitage (an additional 613 pieces of unmodified debitage were recovered from the heavy fractions of the flotation samples but were not analyzed). The majority of the chert raw materials comprising the assemblage are macroscopically similar to primary and secondary chert sources identified throughout the lower Bosque basin by Mehalchick and Kibler (2008:352-356). These cherts are remarkably similar visually (various shades of gray) and fairly distinct. The shades are light olive gray (5Y 6/1), medium gray (N5), medium dark gray (N4), dark gray (N3), and grayish black (N2). All contain tiny microfossils that are white (N9), bluish white (5B 9/1), and light bluish gray (5B 7/1). There is also a banded variety of chert exhibiting light olive gray (5Y 5/2), olive gray (5Y 4/1), and dark gray (N3) bands. It also contains the same tiny white, bluish white, and light bluish gray microfossils.

\section{Projectile Points}

Each of the projectile points exhibits characteristics of certain point types. Five of the specimens are similar to Perdiz points, one is a
Pedernales point, and the last specimen exhibits characteristics of a Godley-like point (Table 3.2). All of the Perdiz arrow points are broken or reworked. Four have base and stem characteristics similar to those seen on Perdiz points. The fifth is broken at the base and the tip. However, the medial section is similar to other Perdiz points.

\section{Godley-Like}

One specimen is an unfinished Godley-like point recovered from Feature 3 in Test Unit 3 at $66 \mathrm{~cm}$ below the surface (Figure 3.1a). The point is complete but may have a reworked or resharpened blade. It has a broad stem with a slightly convex base. Raw material is a mottled light gray, unpatinated fine-grained chert. It has a maximum length of $47.2 \mathrm{~mm}$, a stem length of $13.5 \mathrm{~mm}$, a maximum width of $24.6 \mathrm{~mm}$, and a maximum thickness of $6.2 \mathrm{~mm}$.

\section{Pedernales}

One unfinished Pedernales point was recovered from loose fill on the floor of Backhoe Trench 5 outside of Test Unit 2 (Figure 3.1b). It was out of context, so it could be from any depth $(0-120 \mathrm{~cm})$ within the trench. It has a narrow slightly bifurcated stem. Raw material is a gray, unpatinated fine-grained chert. It has a maximum length of $69.8 \mathrm{~mm}$, a stem length of $13.8 \mathrm{~mm}$, a maximum width of $25.2 \mathrm{~mm}$, and a maximum thickness of $8.9 \mathrm{~mm}$.

\section{Perdiz}

The five Perdiz points were recovered from proveniences generally stratigraphically above the Godley-like specimen. One was recovered from Test Unit 4 at $10-20 \mathrm{~cm}$ below the surface. The tip of the blade and the stem are missing 


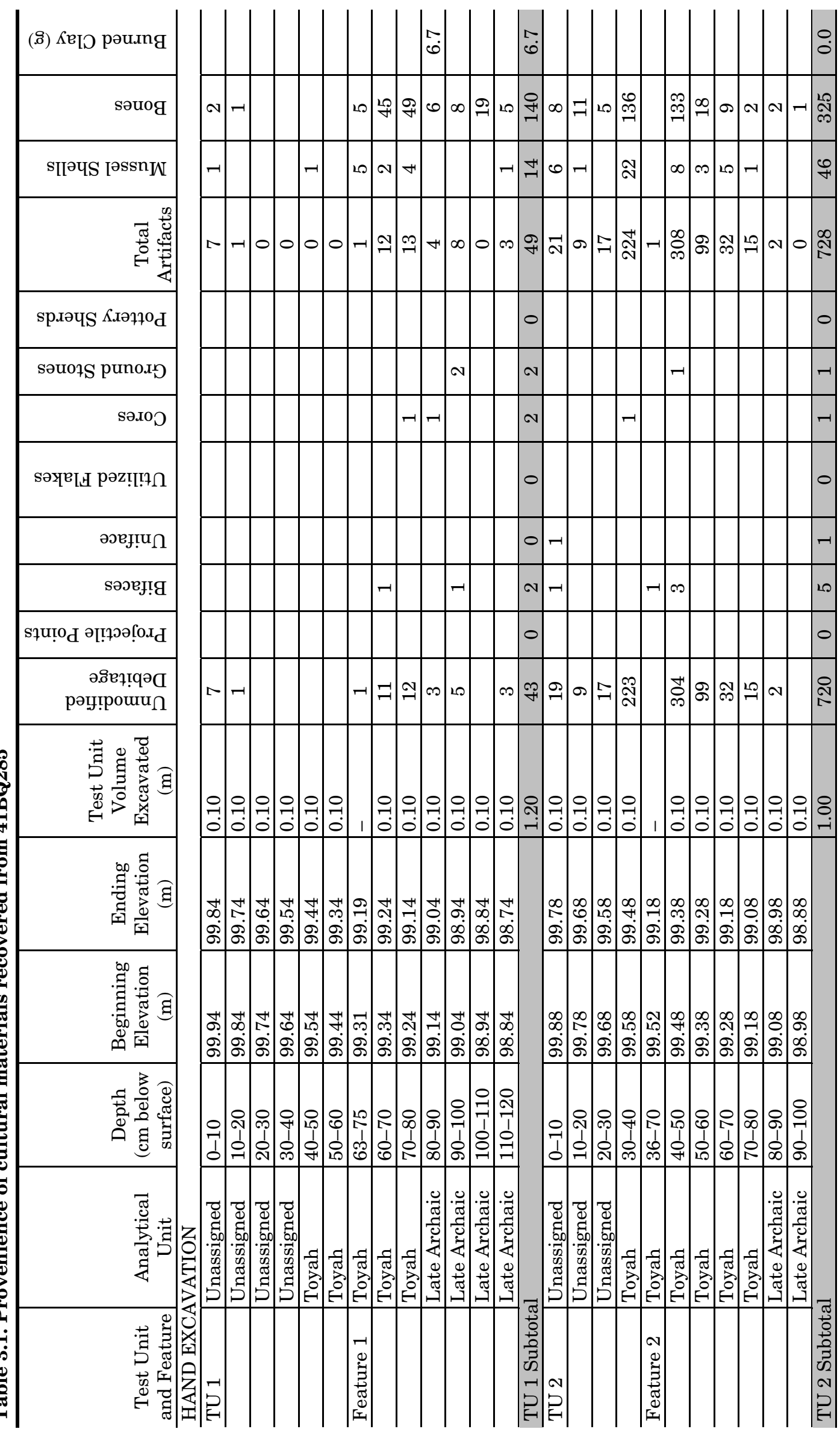




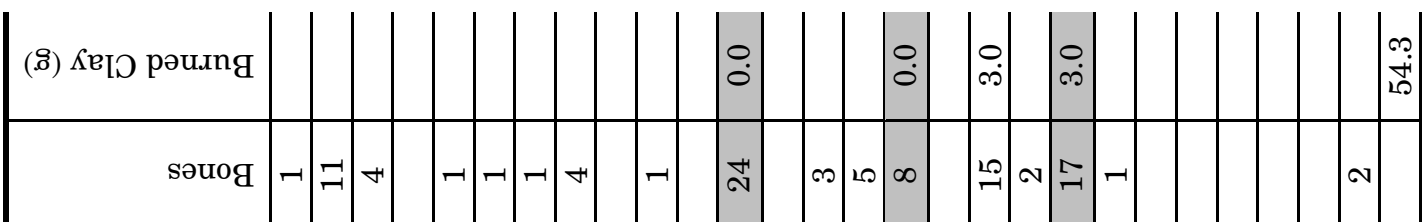

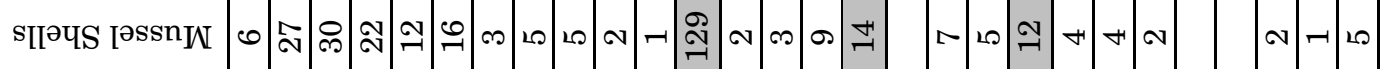

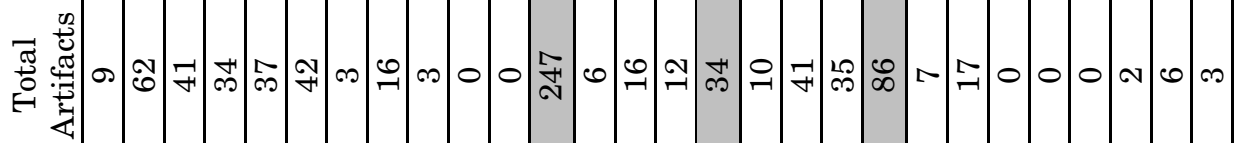
sрләчS K.ләң7о d səuo7s punox’

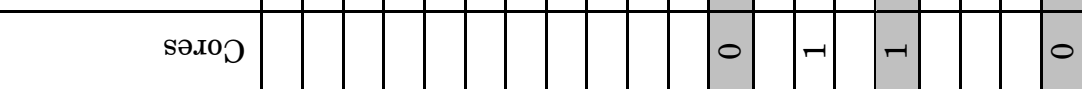

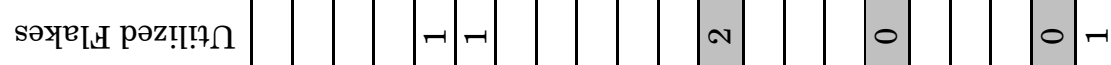

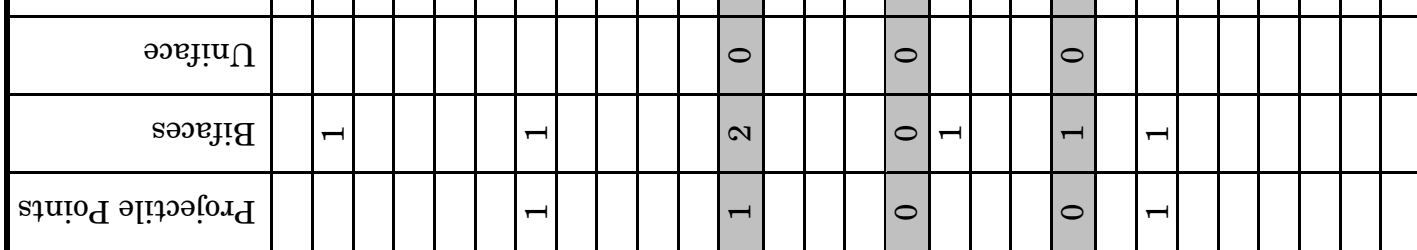

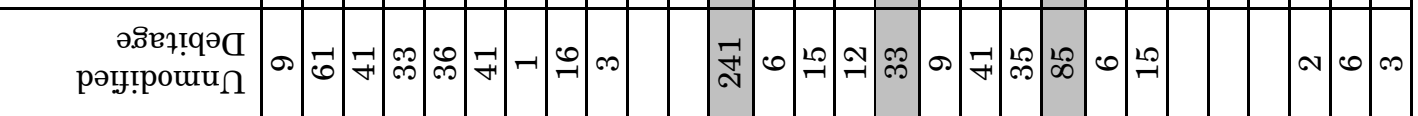

节密

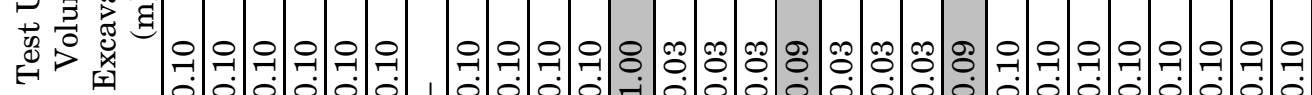

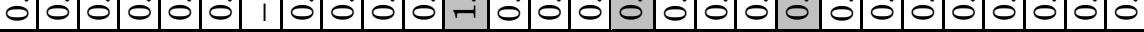

:

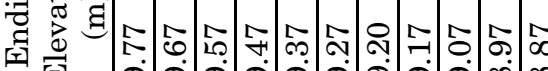
मे में में

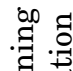

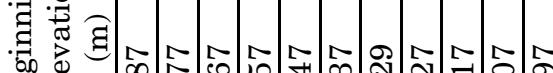

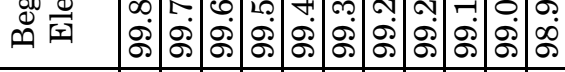

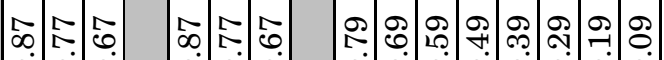
मे தं

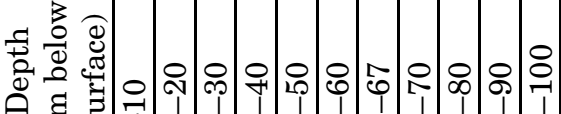

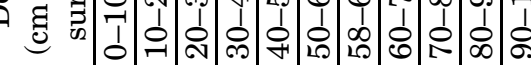

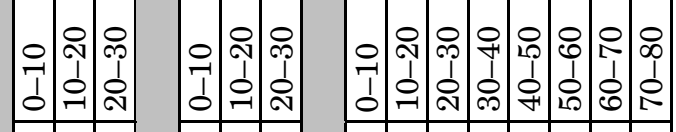

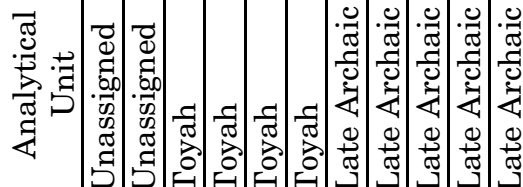
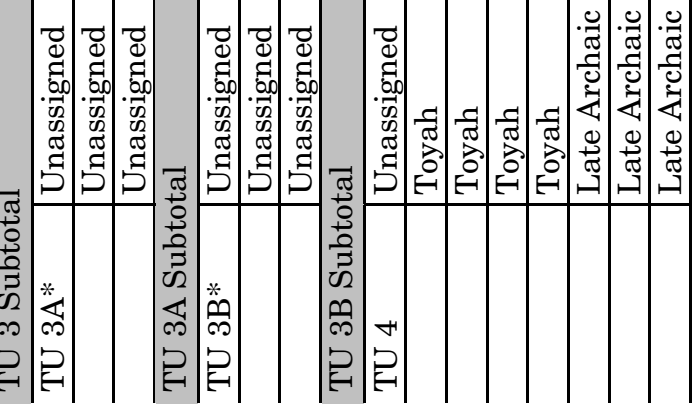
National Register Testing at 41BQ285

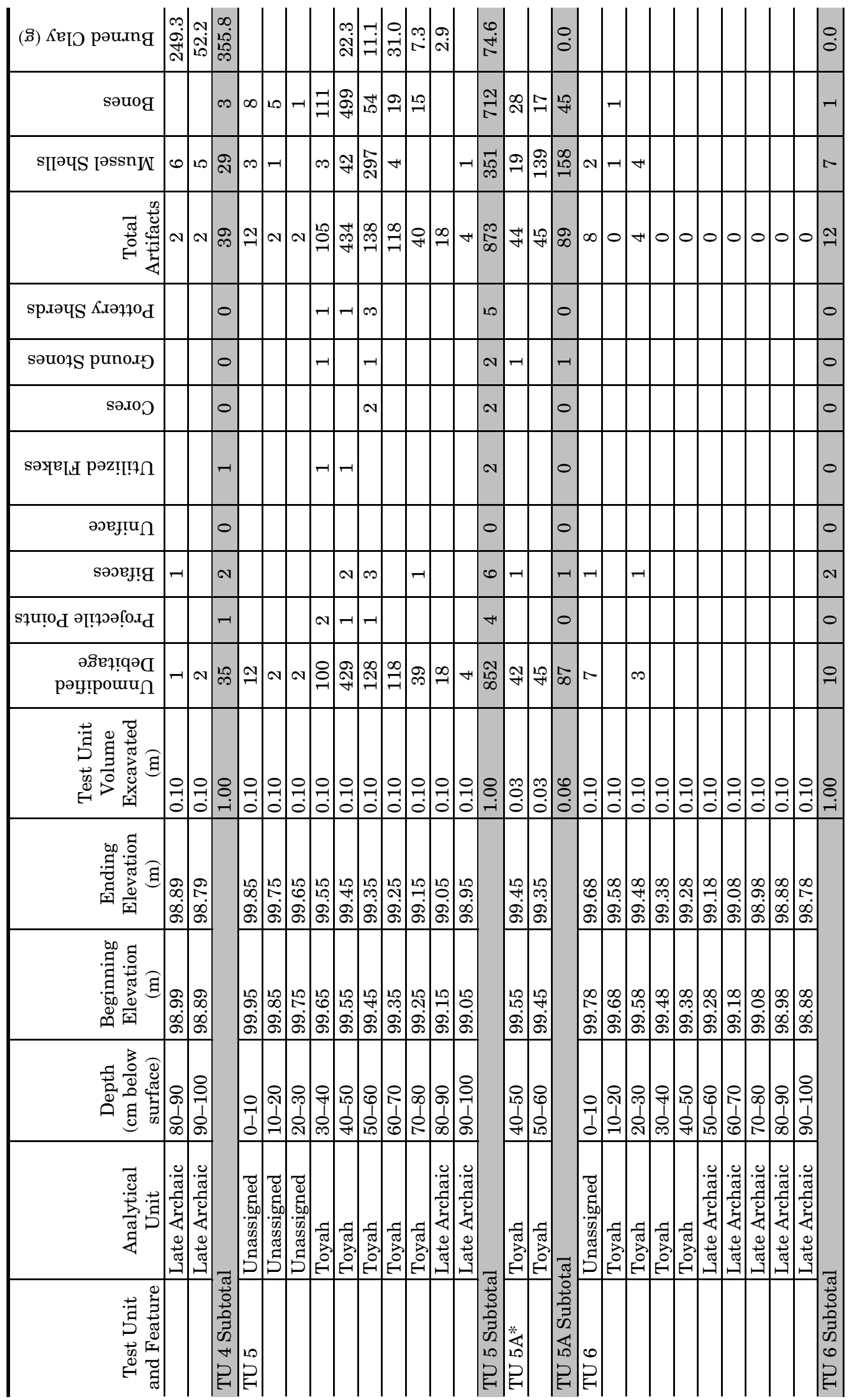




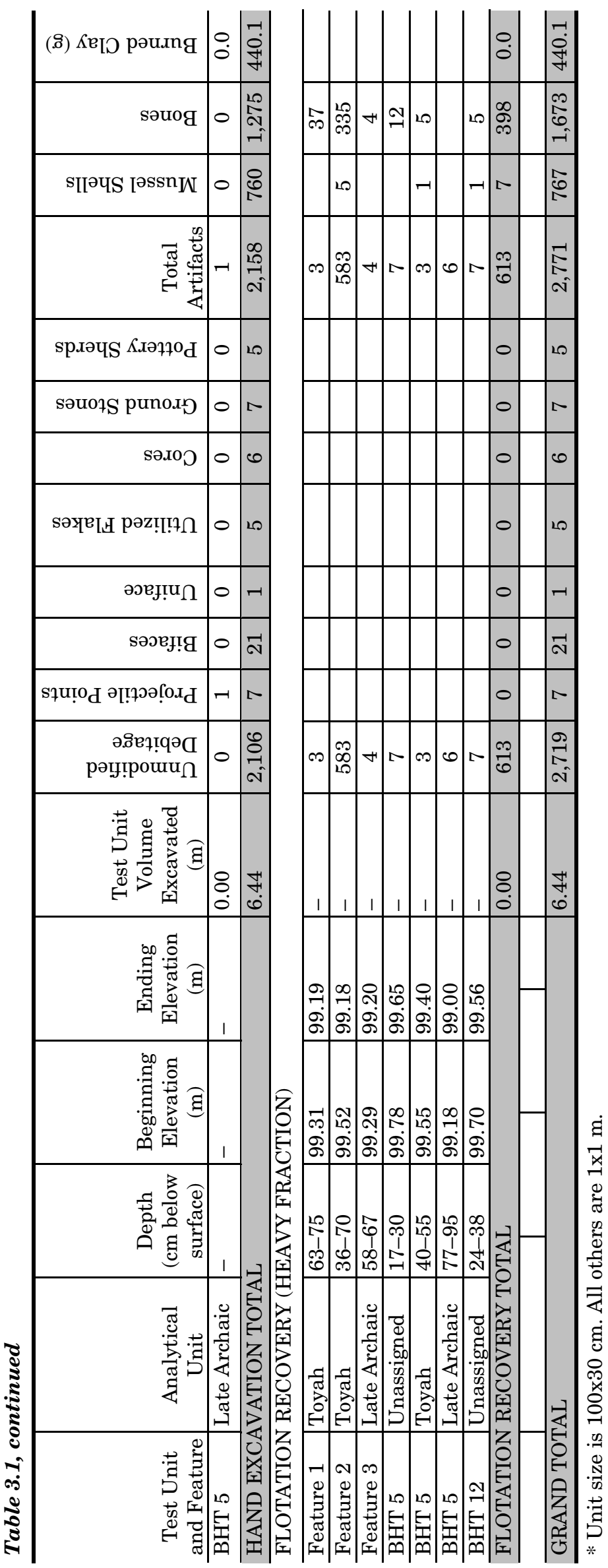


National Register Testing at 41BQ285

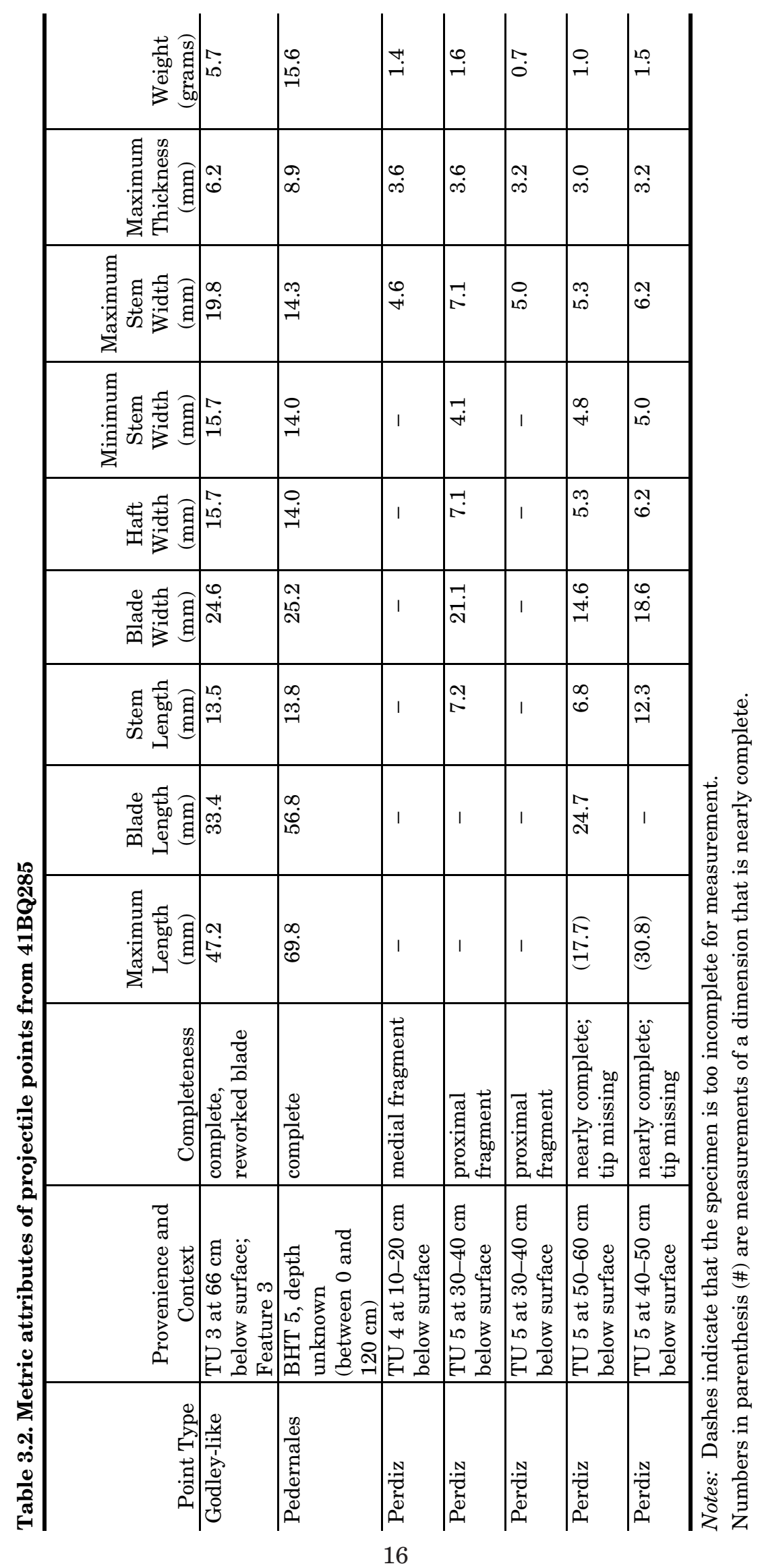



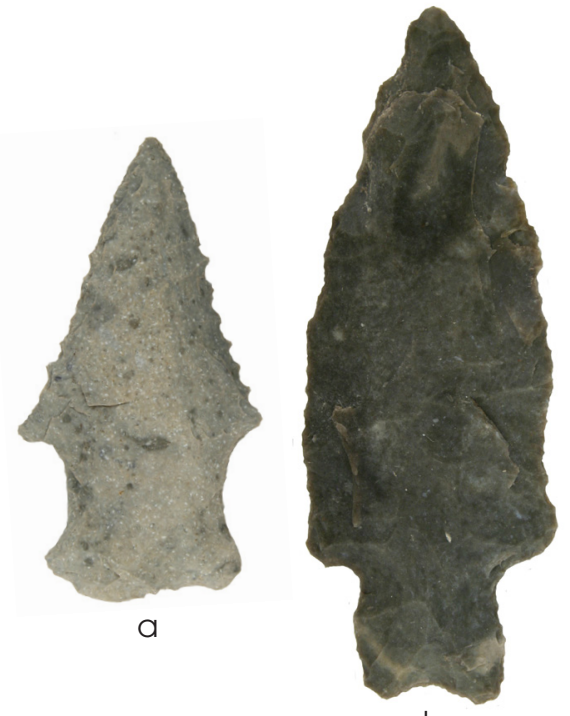

b

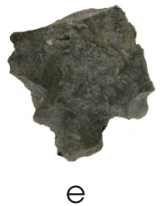

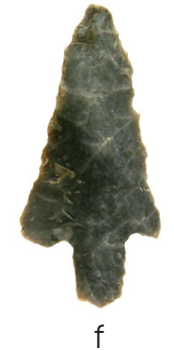

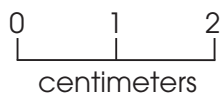

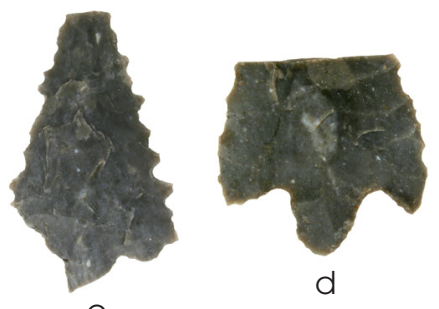

C

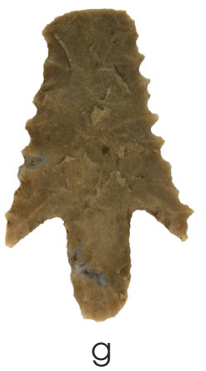

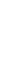

Figure 3.1. Dart and arrow points. (a) Godley-like; (b) Pedernales; (c-g) Perdiz.

due to postdepositional breaks (Figure 3.1c). One of the lateral edges of the blade appears to have been reworked. The raw material is a fine-grained gray chert.

Two specimens were recovered from Test Unit 5 at $30-40 \mathrm{~cm}$ below the surface. Both are proximal fragments (Figure $3.1 \mathrm{~d}-\mathrm{e}$ ). One consists of a small reworked stem and a small portion of the blade, which has been reworked. The other consists of a complete stem. Both are of fine-grained gray chert.

The fourth Perdiz point is from $50-60 \mathrm{~cm}$ in Test Unit 5. It is a nearly complete point with a small section of the tip missing due to a postdepositional break (Figure 3.1f). The lateral blade edges are not serrated. The raw material is a fine-grained gray chert. It has a maximum length of $17.7 \mathrm{~mm}$, a maximum width of $14.6 \mathrm{~mm}$, and a maximum thickness of $3.0 \mathrm{~mm}$.

The final Perdiz point was recovered from Test Unit 5 at $40-50 \mathrm{~cm}$ below the surface. It is finished but is missing the distal tip due to a postdepositional break (Figure $3.1 \mathrm{~g}$ ). It has serrated blade edges. The raw material is a tan to light gray fine-grained chert. It is visually and macroscopically different from the lower Bosque basin cherts identified by Mehalchick and Kibler (2008:352-356) and the vast majority of the materials comprising the site's chipped stone assemblage. It has a maximum length of $30.8 \mathrm{~mm}$, a maximum width of $18.6 \mathrm{~mm}$, and a maximum thickness of $3.2 \mathrm{~mm}$. 


\section{Bifaces}

Twenty-one bifaces and biface fragments were recovered. These range from large indeterminate bifacial tools to possible broken knives and projectile points that lack diagnostic attributes. They consist of 13 indeterminate and early-stage biface fragments (Figure $3.2 \mathrm{a}-\mathrm{d}$ ) and 8 late-stage or preform biface fragments (Figure $3.2 \mathrm{e}-\mathrm{h}$ ). The indeterminate and early-stage biface fragments exhibit percussion flake scars, and many retain some cortex. These specimens are thick and crude and ovoid in shape and are large enough for further reduction. They do not display any edge modification or morphology that would allow them to be placed into a tool category. They range from 31.6 to $44.3 \mathrm{~mm}$ long, 25.0 to $33.9 \mathrm{~mm}$ wide, and 14.3 to $17.3 \mathrm{~mm}$ thick. The late-stage or preform bifacial tools exhibit pressure flaking and represent possible broken knives, arrow points, and late-stage preforms. None of these specimens retain any cortex.
These range from 14.3 to $29.9 \mathrm{~mm}$ long, 13.3 to $15.8 \mathrm{~mm}$ wide, and 2.2 to $3.3 \mathrm{~mm}$ thick. All of the bifaces and biface fragments are of fine-grained light to dark gray cherts, similar to those cherts found throughout the lower Bosque basin.

\section{Uniface}

Only one unifacial tool was recovered from Test Unit 2 at $0-10 \mathrm{~cm}$ below the surface. This specimen appears to be a side scraper exhibiting pressure flake scars on one side of a flake. It does not retain any cortex. It consists of fine-grained gray chert. It has a maximum length of $6.2 \mathrm{~mm}$, a maximum width of $3.1 \mathrm{~mm}$, and a maximum thickness of $2.0 \mathrm{~mm}$.

\section{Utilized Flakes}

Five utilized flakes were recovered. Each exhibits some amount of use wear along at least one edge of the flake. Two of these are from

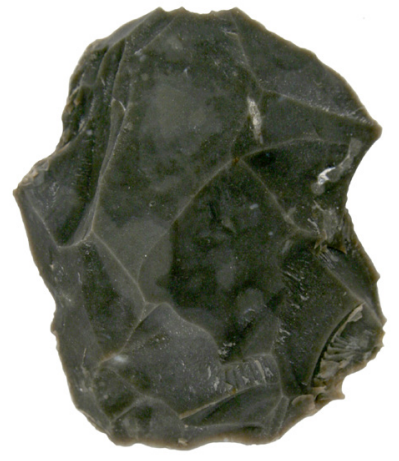

a

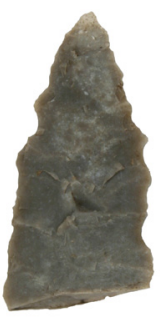

e

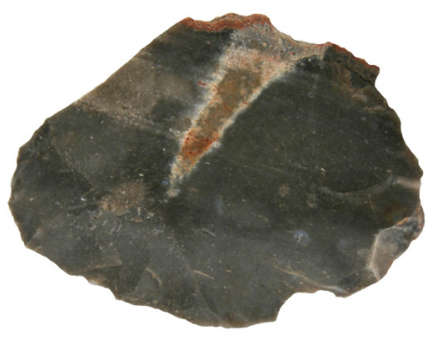

b

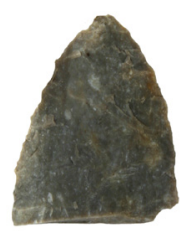

f

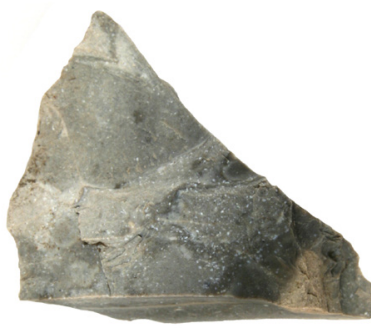

C

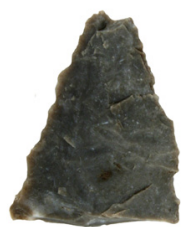

g

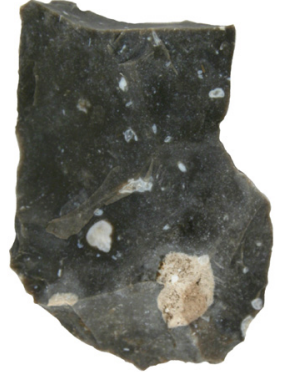

d

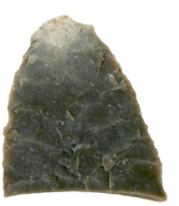

h

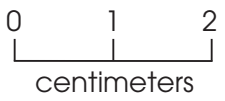

Figure 3.2. Bifaces. (a-d) Indeterminate and early-stage; (e-h) late-stage or preforms. 
$40-60 \mathrm{~cm}$ in Test Unit 3; one is from $10-20 \mathrm{~cm}$ in Test Unit 4; and two are from $30-50 \mathrm{~cm}$ from Test Unit 5. These range from 21.3 to $34.1 \mathrm{~mm}$ long, 19.4 to $28.4 \mathrm{~mm}$ wide, and 8.3 to $16.2 \mathrm{~mm}$ thick.

\section{Cores}

Six cores were recovered. Four are of finegrained gray chert, and the other two are finegrained tan chert. Both of these raw materials are well represented in the tool assemblage and unmodified flakes recovered at the site.

Two cores are from Test Unit 1. One, from $70-80 \mathrm{~cm}$ below the surface, retains approximately 35 percent of its cortex. The cortex is heavily weathered, and the specimen appears to have originated from an upland context. The raw material is a fine-grained gray chert. It has a maximum length of $50.5 \mathrm{~mm}$, a maximum width of $41.9 \mathrm{~mm}$, and a maximum thickness of $29.2 \mathrm{~mm}$. The second core is $80-90 \mathrm{~cm}$ below the surface. It also retains approximately 35 percent of heavily weathered cortex. The raw material is fine-grained gray chert. It has a maximum length of $60.4 \mathrm{~mm}$, a maximum width of $46.3 \mathrm{~mm}$, and a maximum thickness of $26.6 \mathrm{~mm}$.

One core was found in Test Unit 2 at $30-40 \mathrm{~cm}$. It retains approximately 20 percent weathered cortex. The raw material is finegrained white to gray chert. It has a maximum length of $97.1 \mathrm{~mm}$, a maximum width of $63.8 \mathrm{~mm}$, and a maximum thickness of $36.2 \mathrm{~mm}$. Two cores were recovered from Test Unit 5 at $50-60 \mathrm{~cm}$. Both are of fine-grained gray chert with stream-rolled cortex; one has approximately 25 percent cortex, and the other has about 40 percent. The sixth core recovered came from Test Unit $3 A$ at $10-20 \mathrm{~cm}$. Approximately 10 percent of the core is covered with weathered cortex. The raw material is fine-grained gray chert. It has a maximum length of $51.5 \mathrm{~mm}$, a maximum width of $33.6 \mathrm{~mm}$, and a maximum thickness of $23.8 \mathrm{~mm}$.

\section{Unmodified Debitage}

A total of 2,106 pieces of unmodified debitage were recovered from the hand excavations. Of those, 1,744 specimens (83 percent) are chips, 215 (10 percent) are proximal flake fragments, 75 (4 percent) are chunks, and 72 (3 percent) are complete flakes. Most of the unmodified debitage $(1,654$ pieces or 79 percent) has no cortex, while 437 pieces have 25 percent or less dorsal cortex, and 15 pieces have between 26 and 50 percent dorsal cortex. There are no flakes with more than 50 percent dorsal cortex. Of the complete flakes, 74 percent lack cortex entirely, and 19 percent have 1-50 percent cortex. Of those specimens retaining cortex, weathered or chalky cortex is present on 343, while 109 pieces of exhibit stream-rolled or abraded cortex. The cortex characteristics suggest that onsite reduction strategies were geared toward the latter stages of reduction and resharpening. Cortex characteristics also suggest that raw materials were mostly collected from primary sources, one of which is present ca. $0.7 \mathrm{~km}$ north of the site along the valley wall (Locality 12a in Mehalchick and Kibler 2008:352-356). Secondary sources also were used, but to a lesser extent. Gravel bars below the site (Locality 12b in Mehalchick and Kibler 2008:352-356) do contain some bedload cherts.

Overall the unmodified debitage assemblage consists of small flakes and flake fragments. Nearly 90 percent $(n=1,875)$ are $30 \mathrm{~mm}$ or less in size. Complete flakes are distributed throughout most size classes with most falling between 31 and $40 \mathrm{~mm}$. Most of the chunks $(\mathrm{n}=49)$ are between 11 and $30 \mathrm{~mm}$. Most of the chips are between 11 and $30 \mathrm{~mm}$. Proximal flake fragments are mostly between 21 and $40 \mathrm{~mm}$.

Only 63 pieces in the unmodified debitage assemblage show thermal alteration. Most of these specimens exhibit discoloration. Several also show crazing and potlids. These characteristics suggest that most of the thermally altered pieces of debitage were culturally modified (i.e., heat-treated) to aid the knapping process and are not the result of burning in intensive fires.

\section{GROUND AND BATTERED STONE TOOLS}

All seven of the ground and battered stone tools are fine- to medium-grained quartzites. Quartzitic rocks can be found in nearby Tertiaryage lag gravels that mantle the high surface divide between the North Bosque and Brazos Rivers (Hayward et al. 1996:1-22 to 1-27). Three show signs of battering and hammering on at least one end or side, suggesting that they functioned as hammerstones (Figure 3.3a-c). Each of these also contains a grinding facet on 

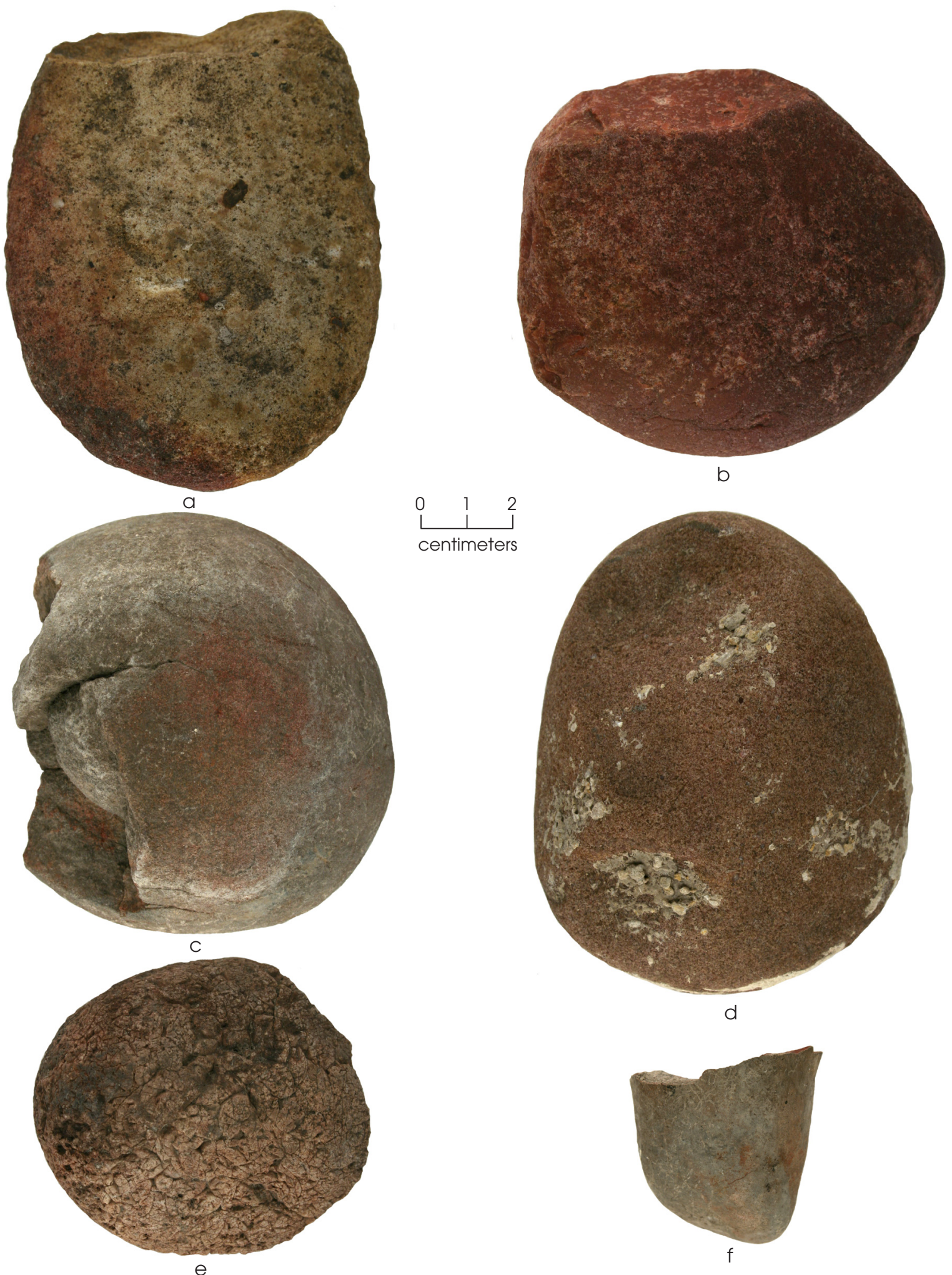

Figure 3.3. Ground and battered stone tools. (a-c) Hammerstones and grinding stones; (d-f) grinding stones. 
one side suggesting it also served as a grinding implement. The four others are worn smooth on at least one side, suggesting they were also used as grinding stones (Figure $3.3 \mathrm{~d}-\mathrm{f}$ ).

\section{CERAMICS}

Five ceramic sherds were recovered from 41BQ285. All five sherds are from Test Unit 5 $(30-60 \mathrm{~cm})$. These sherds are described in detail, and the results of petrographic and instrumental neutron activation analyses presented, in Appendix $\mathrm{C}$, but some general observations and interpretations about the ceramic assemblage are offered here.

The specimens are five body sherds from at least four different vessels. One of the sherds is from an engraved carinated bowl, while the vessel types for the other four sherds are not known. All are less than $50 \mathrm{~mm}$ in maximum dimension, and four are smaller than $30 \mathrm{~mm}$. Sherd thickness ranges from 5.8 to $8.2 \mathrm{~mm}$. Four of the five sherds appeared to be grog-tempered when examined under low-power magnification, although subsequent petrographic analysis did not confirm the presence of grog temper in three of the four sherds. The petrographic analysis indicated that only the engraved carinated bowl sherd contained grog temper. The fifth specimen contains a sparse amount of burned bone temper.

Two sherds are plain, displaying no decoration (Figure $3.4 \mathrm{a}-\mathrm{b}$ ), while decorative motifs are present on the other three sherds. The engraved carinated bowl displays a panel of diagonal lines on and below the rim (Figure 3.4c). The other two decorated sherds have single fingernail punctations (Figure 3.46d-e). Three sherds have been burnished on one or both surfaces, while the other two sherds have smoothed vessel surfaces. Both surfaces of the engraved carinated bowl sherd have been burnished, while one fingernail punctated sherd has been smoothed on both surfaces.

Typological identifications for these sherds are not attempted here, although the decorative elements and grog tempering of the engraved carinated bowl and the fingernail punctations on two of the other sherds are indicative of various Caddo types. The mineralogical and chemical composition of these sherds, however, tells a different story (see Appendix C).

The results of the petrographic analysis indicate the sherd assemblage consists of two different paste groups. The engraved carinated bowl sherd is the sole member of one paste group, while the remaining sherds belong to the second paste group. The petrographic analysis results also suggest that the engraved carinated bowl sherd could be east Texas Caddo in origin, whereas the sherds of the second paste group, including the two with fingernail punctations, have a probable local origin. The results of the instrumental neutron activation analysis (INAA), however, indicate that all five sherds, including the engraved carinated bowl sherd, are of local origin. In Appendix $\mathrm{C}$ of this report, Perttula et al. discuss the various scenarios regarding the production and use of the vessels represented by the 41BQ285 ceramic assemblage, but as they note, what cannot be currently addressed is the ethnicity or cultural affiliation of the group that made and used these vessels.

\section{OTHER CULTURAL MATERIALS}

Other cultural materials recovered from 41BQ285 consist of 1,674 vertebrate faunal remains (398 of the 1,674 specimens are from flotation samples), 767 freshwater mussel shells ( 7 of the 767 specimens are from flotation samples), $118 \mathrm{~kg}$ of burned rocks from feature and nonfeature contexts, $440.1 \mathrm{~g}$ of burned clay, and 1 human tooth.

Vertebrate faunal remains represent the second most abundant material type recovered from the site (see Appendix A). Although the assemblage is highly fragmentary, nearly 60 percent of the specimens $(n=999)$ are identifiable to the class level or below. Deer or deer-sized elements dominate the identifiable remains, with 50 deer (Odocoileus sp.) specimens and 890 specimens identified as deer family (Cervidae), deer- to pronghorn-sized artiodactyl, and canid- to deer-sized mammal. Most of the latter specimens also probably represent deer, since specimens unequivocally identified as pronghorn antelope and bison are absent from the assemblage. Together these specimens represent at least three deer, including one subadult. The remaining 59 identifiable specimens primarily represent small mammals, reptiles (predominately turtles), and birds. Two specimens consist of a single gar scale and one deer- to bison-sized long bone shaft fragment that is most likely from a large artiodactyl such as a bison or elk. 


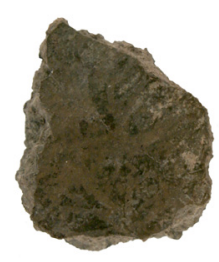

a

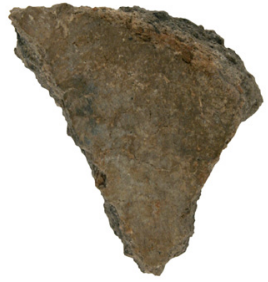

$\mathrm{b}$
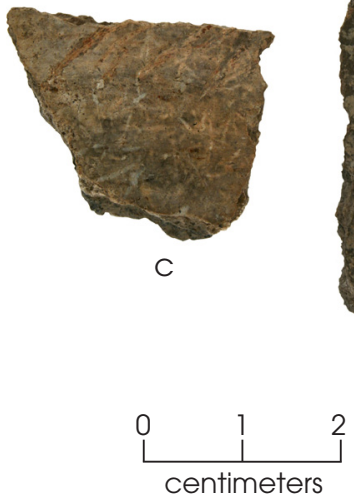
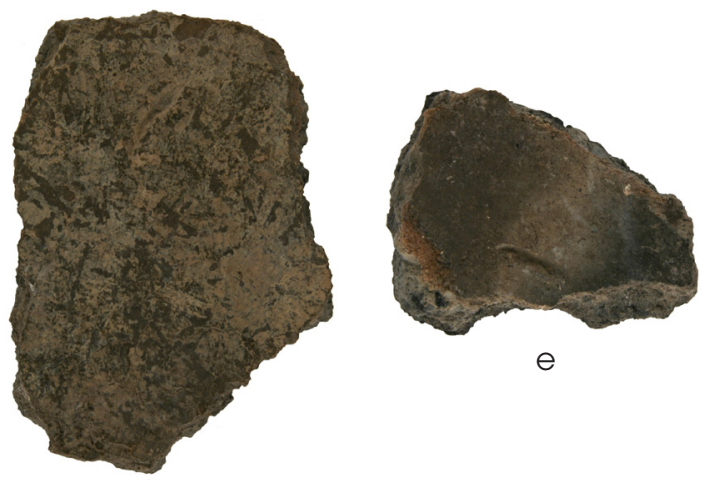

d

Figure 3.4. Ceramic sherds. (a) Plain sherd, Lot 52; (b) plain sherd, Lot 53-1; (c) engraved sherd, Lot 51; (d) fingernail punctate sherd, Lot 53-3; (e) fingernail punctate sherd, Lot 53-2.

Spiral and impact fractures are present on 415 specimens, or over 24 percent of the assemblage. Many of these taphonomic characteristics occur on the deer and deer-sized elements and are indicative of extensive marrow and bone grease processing. Burned bones also are common, with burning evident on 398 (24 percent) specimens. Cut marks are present only on one specimen, a large bird bone. Other taphonomic characteristics such as extensive weathering and rodent and carnivore gnawing are either limited or absent, suggesting that the assemblage was minimally exposed prior to burial.

One additional specimen that was not part of the 1,673 specimens examined by Shaffer is a modified bone fragment from Test Unit 5 at $40-50 \mathrm{~cm}$. The specimen is a long bone fragment from a deer- to pronghorn-sized artiodactyl. One side of one end of the fragment is smoothed to a small slight point and may represent a small bone awl or perforator. It is $40.4 \mathrm{~mm}$ long, $7.6 \mathrm{~mm}$ wide, and $4.4 \mathrm{~mm}$ thick.

The freshwater mussel shell assemblage consists of 767 intact valves and umbo fragments (see Appendix D). Nine different genera or species were identified in the assemblage. The most common species identified is Threeridge (Amblema plicata), which comprises 62 percent ( $\mathrm{n}=479$ ) of the assemblage. Not surprisingly, Threeridge was the most common species identified within the assemblages recovered just downstream at the Britton (54 percent), Hig- ginbotham (62 percent), and McMillan (69 percent) sites (Gardner 2008). Other identified taxa account for less than 12 percent of the assemblage each. They include Tampico Pearlymussel (Cyrtonaias tampicoensis), Louisiana Fatmucket (Lampsilis hydiana), Yellow Sandshell (Lampsilis teres), Fragile Papershell (Leptodea fragilis), Bleufer (Potamilus purpuratus), Smooth Pimpleback (Quadrula houstonesis), Pistolgrip (Tritogonia verrucosa), and Quadrula sp. Unidentifiable valves or fragments account for 82 specimens (11 percent). A total of 31 specimens are burned. Across all species and genera the sizes of the shells are relatively small compared to modern samples, suggesting that the occupants of 41BQ285 intensively exploited mussels.

The identified mussel species in the 41BQ285 assemblage represent a wide range of aquatic habitats, ranging from slow-moving to swift current, murky to clear water, and shallow to deep water. They also live on a broad range of substrates, including muddy, sandy, and gravelly (fine and course) bottoms. These mussels are not particularly good as paleoenvironmental indicators, but they do reveal something about the river and tributaries near the site. Howells et al. (1996:14) note that "more stable habitats may have larger and more diverse populations than do smaller and less stable waters." The diversity of mussels found at 41BQ285 probably indicates that the North Bosque River was a healthy river system at the time of the prehistoric occupations. 
It may also indicate that the people living at the site were collecting mussels from a variety of locations, including the river and many smaller tributaries.

Burned rocks were recovered from feature $(76 \mathrm{~kg})$ and nonfeature $(42 \mathrm{~kg})$ contexts. Most were limestone clasts exhibiting evidence of heating such as thermal discoloration, angular fractures, or spalling. All of these burned rocks are considered to have been heated intentionally and were probably used as heat-retaining stones for cooking and heating. The $440.1 \mathrm{~g}$ of burned clay recovered also probably relate to these features, representing sediments incidentally fired during feature use.

In addition, a single human molar was recovered from Test Unit 3 in the upper $5 \mathrm{~cm}$ of loose construction fill of Level 1. Archeologists with the Environmental Affairs Division (ENV) of TxDOT in Austin were notified upon discovery of the tooth. After consultation with ENV, Test Unit 3 was expanded $30 \mathrm{~cm}$ to the north and south. These add-on units, designated $3 \mathrm{~A}$ (north) and $3 \mathrm{~B}$ (south), were created and excavated to $30 \mathrm{~cm}$ below surface in a search for additional human remains and evidence of a burial pit, neither of which was found. The tooth was collected and taken to the laboratory at Prewitt and Associates, Inc. for further identification and analysis. The tooth is a right maxillary first molar. The roots are broken with one-quarter to half of the roots present. The crown of the tooth is complete and shows minimal wear, with cusps slightly rounded to distinct. Its mesiodistal diameter is $11.19 \mathrm{~mm}$, buccolingual diameter is $11.97 \mathrm{~mm}$, and crown height is $7.39 \mathrm{~mm}$. The wear indicates the tooth was in occlusion, which occurs around the age of $7 \pm 2$ years. Otherwise there is little additional evidence to conclusively determine whether the tooth is from a young adult or subadult.

A variety of botanical remains were recovered from flotation of sediment associated with Features 1 and 2 in the Late Prehistoric occupation. The unburned remains are not considered to be cultural, but the charred remains are indicative of the wood fuels and plant foods that were used (see Appendix B, Table B3). The charred wood types recovered are oak (including white and red), elm, hackberry, willow, willow/cottonwood, ash, sycamore, yaupon, and pecan/hickory. Plant remains that probably represent foods are pecan (nutshell and nutmeat) and oak acorns, along with seeds of chenopodium, elderberry, pokeweed, and little barley. Cleavers seeds were also recovered, but these probably represent a plant that invaded the site between occupations rather than a food resource. All of these resources represent common plants that would have been available in close proximity to 41BQ285. They indicate that the Late Prehistoric Toyah Interval riverine habitat and environment were probably quite similar to conditions today. It is notable that the archeological assemblage contains no mesquite or juniper, both being species that became much more frequent in modern times. Their absence in the Late Prehistoric sample from 41BQ285 does not mean that they were not present, but suggests that there were fewer mesquite and juniper trees than there are today.

\section{CULTURAL FEATURES}

Three cultural features were exposed and excavated. All were between 30 and $75 \mathrm{~cm}$ below the ground surface. One charcoal sample was collected from Feature 1 and nine from Feature 2. No charcoal was encountered during the excavation of Feature 3. Matrix was collected from all three features for flotation. Five AMS radiocarbon dates were obtained on charred plant remains (Table 3.3).

\section{Feature 1}

Feature 1 was in Test Unit 1 between 63 and $75 \mathrm{~cm}$ below the surface (Figure 3.5 ). The feature measured $90 \times 92 \mathrm{~cm}$. It consisted mostly of a scatter of bones and four burned rocks with no recognizable pattern in their placement; hence, the feature appears to be disturbed. The bones, recovered from hand excavations and flotation samples, represent 1 deer, 3 deer- to pronghorn-sized artiodactyl, 2 canid- to deersized mammal, and 36 vertebrata elements. In addition, 5 mussel shells and 4 pieces of lithic debitage were recovered from the feature. The rocks were moderately fractured, between 10 and $20 \mathrm{~cm}$ in diameter, and weighed a total of $2.0 \mathrm{~kg}$. The fill among the rocks resembled the surrounding sediment. One small isolated piece of charcoal was collected from the feature and submitted for radiocarbon dating. It yielded a ${ }^{13} \mathrm{C}$ corrected age of $630 \pm 40$ B.P. (see Table 3.3). Fine-grained matrix or sediment samples were collected and processed through flotation. Light 
Table 3.3. Radiocarbon dates from $41 B Q 285$

\begin{tabular}{c|c|c|c|c|c|c|c}
\hline $\begin{array}{c}\text { Beta } \\
\text { Lab No. }\end{array}$ & $\begin{array}{c}\text { Test } \\
\text { Unit }\end{array}$ & Elevation & Feature & $\begin{array}{c}{ }^{14} \text { C Age } \\
\text { (B.P.) }\end{array}$ & ${ }^{13}$ C & $\begin{array}{c}\text { 2-Sigma } \\
\text { C Corrected } \\
\text { Age (B.P.) }\end{array}$ & $\begin{array}{c}\text { Calibrated Date } \\
\text { Range }\end{array}$ \\
\hline 217889 & 2 & $99.56 \mathrm{~m}$ & - & 65040 & -24.9 & 65040 & A.D. 1280-1400 \\
\hline 217890 & 1 & $99.26 \mathrm{~m}$ & 1 & 65040 & -26.5 & 63040 & A.D. 1290-1410 \\
\hline 217891 & 2 & $99.42 \mathrm{~m}$ & 2 & 54040 & -26.7 & 51040 & A.D. 1400-1450 \\
\hline 217892 & 2 & $99.18 \mathrm{~m}$ & 2 & 47040 & -28.1 & 42040 & $\begin{array}{c}\text { A.D. 1420-1520 } \\
\text { and A.D. 1590- } \\
\end{array}$ \\
& & & & & & & 33040 \\
\hline 217893 & 4 & $99.38 \mathrm{~m}$ & - & 33040 & -25.1 & A.D. 1460-1650 \\
\hline
\end{tabular}

Note: All are AMS dates on charcoal.

fraction recovery yielded pieces of charred white oak, elm, hackberry, and sycamore, and one charred cleavers seed (Galium spp.).

\section{Feature 2}

Feature 2 was in Test Unit 2 between 36 and $70 \mathrm{~cm}$ below the surface. It consisted of a circular accumulation of burned rocks in the southern half of the unit (Figure 3.6). The feature extended into the south wall of Test Unit 2 , but its excavated dimensions were $83 \times 45 \mathrm{~cm}$. The rocks associated with the upper portion were smaller and more fractured, while larger rocks were associated with the lower levels of the feature and appeared to line a basin-shaped

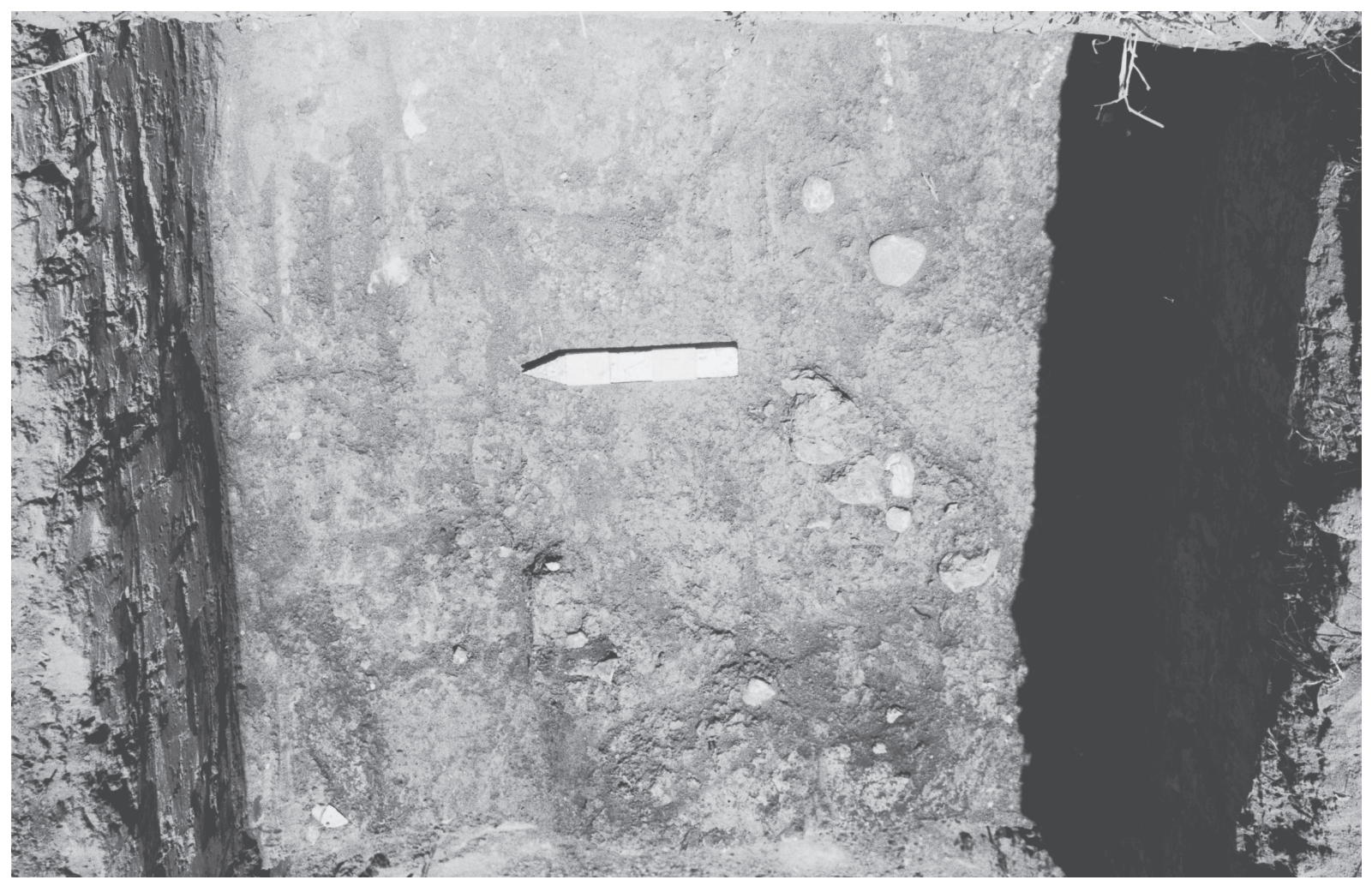

Figure 3.5. Feature 1 in Test Unit 1. 


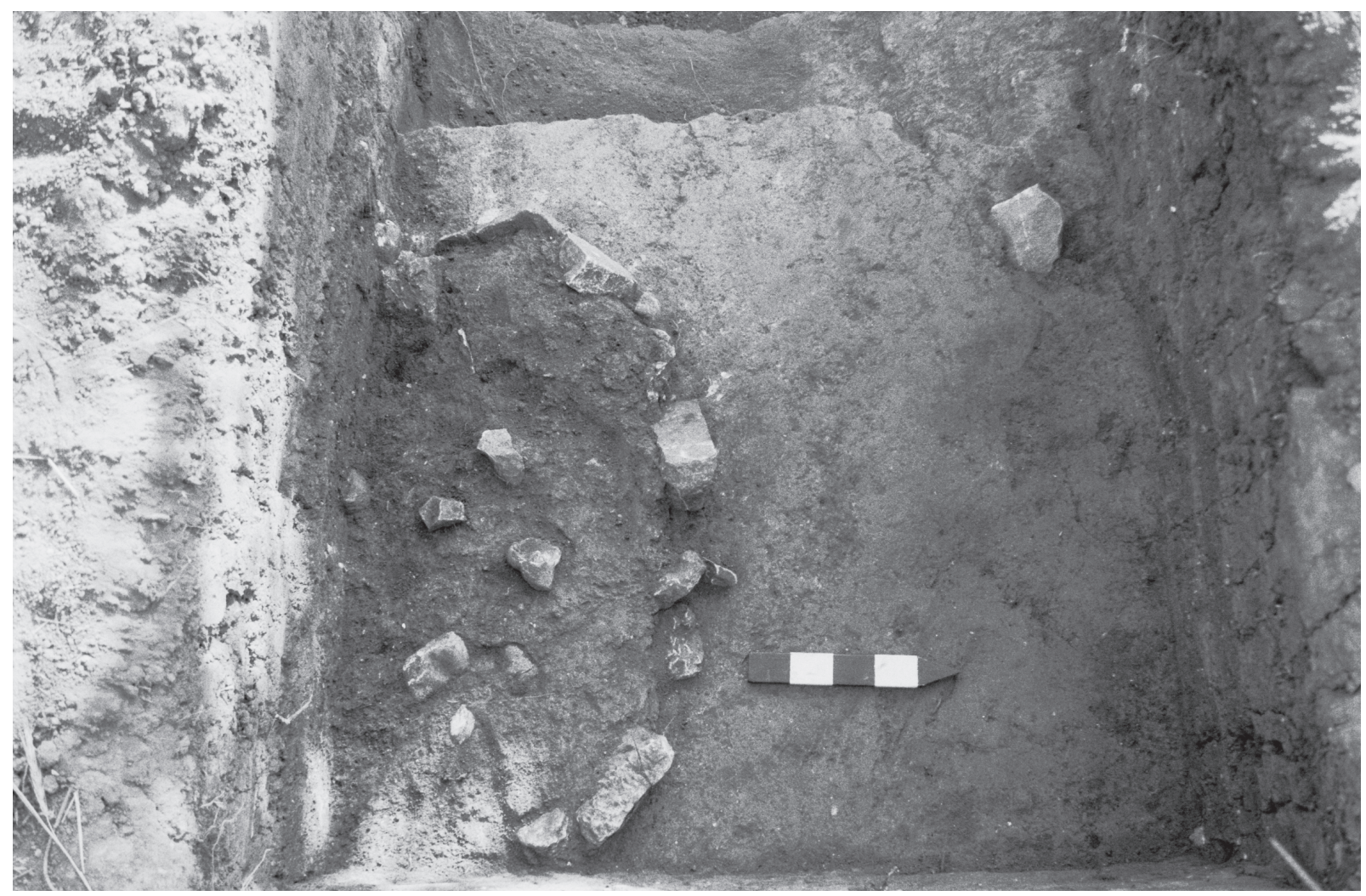

Figure 3.6. Feature 2 in Test Unit 2.

pit. Most of the rocks appeared burned on the bottom. A total of $52.8 \mathrm{~kg}$ of burned rocks was removed from this feature. A 5-10-cm-thick layer of charcoal was immediately underlying the bottom rocks. One biface was associated with the feature.

A total of nine charcoal samples were collected, of which two were submitted for radiocarbon dating. The two samples yielded ${ }^{13} \mathrm{C}$ corrected ages of $510 \pm 40$ and $420 \pm 40$ B.P. (see Table 3.3). The position of the rocks and charcoal suggest that Feature 2 was an intact hearth. A number of fine-grained matrix samples were collected from the feature. Cultural materials recovered from the heavy fraction of these flotation samples consisted of 583 pieces of debitage, 335 bone fragments, and 5 mussel shells. The vertebrate faunal remains represent 1 deer, 2 deer- to pronghornsized artiodactyl, 59 canid- to deer-sized mammal, 2 rabbit- to canid-sized mammal, 1 rabbit, 1 medium-sized rodent, 1 large bird, 3 snakes, 2 turtle, and 263 vertebrate elements.
The light fraction yielded various charred woods and nutshell and nutmeat fragments. White oak (Quercus L. subgenus Quercus) and oak (Quercus spp.) were the most prominent taxa within the charred wood assemblage, followed by elm, hackberry, and ash. The charred nut sources were overwhelmingly represented by pecan. Carbonized seeds, consisting of cleavers (Galium spp.), chenopodium (Chenopodium spp.), elderberry (Sambucus nigra), pokeweed (Phytolacca americana), little barley (Hordeum pusillum), and one gourd rind (cf. Cucurbita texana) were also recovered from the light fraction.

\section{Feature 3}

Feature 3 was in Test Unit 3 between 58 and $67 \mathrm{~cm}$ below the surface (Figure 3.7 ). The feature consisted of a dense accumulation of burned rocks associated with the eastern half of a basin-shaped hearth. The western half had 


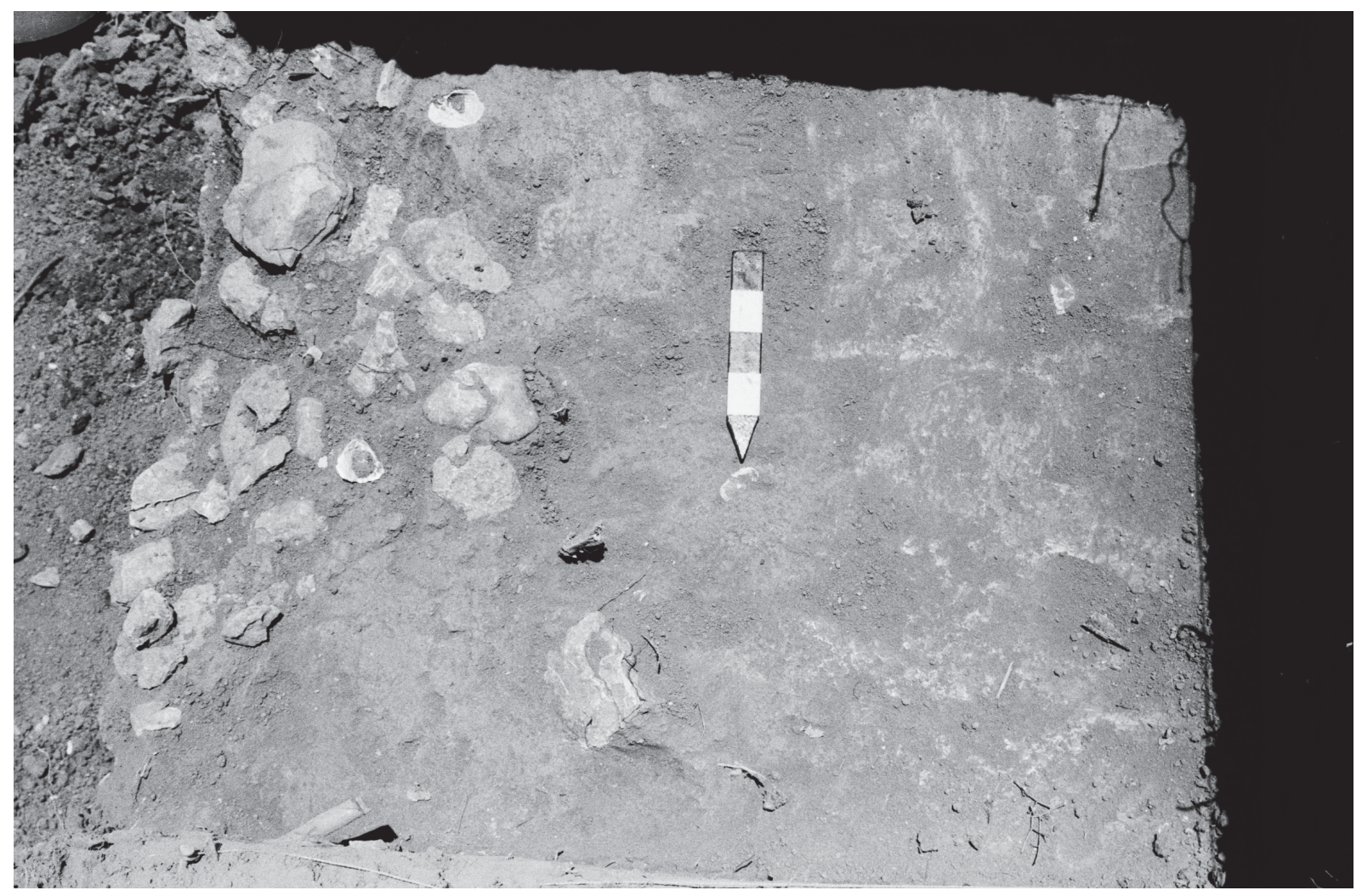

Figure 3.7. Feature 3 in Test Unit 3.

been removed during excavation of Backhoe Trench 6. Its excavated dimensions were $62 \times 91 \mathrm{~cm}$. A total of $21.2 \mathrm{~kg}$ of burned rocks was removed from this feature. Most of the rocks were between 5 and $10 \mathrm{~cm}$ long. The burned rocks were mostly angular and cracked, with minimal discoloration from burning. Several of the rocks sloped inward and westward, forming a partial basin. The arrangement of the burned rocks suggests that Feature 3 was a disturbed basin-shaped hearth. Two chipped stone tools were associated with Feature 3, a Godley-like dart point recovered at $66 \mathrm{~cm}$ below the surface and a biface recovered at $63 \mathrm{~cm}$. Three mussel shells, 1 piece of debitage, and 1 piece of bone (vertebrate) were also recovered. No charcoal was observed or collected from processed flotation samples. The flotation samples did, however, produce 4 pieces of debitage and 4 pieces of bone (vertebrate). 


\section{ARTIFACT AND FEATURE DISTRIBUTIONS AND DEFINITION OF SITE COMPONENTS}

\section{4}

Basic provenience information for the cultural materials recovered from 41BQ285 is presented in Table 3.1. Although the site spans an area about $30 \mathrm{~m}$ north-south by $6 \mathrm{~m}$ eastwest, the horizontal distributions of features and cultural materials indicate that the cultural activities were most concentrated in the central portion of the site, in the vicinity of Test Units 2, 3, and 5. Far fewer artifacts were recovered from Test Units 1, 4, and 6.

Test Unit 5 yielded 852 pieces of debitage, the most of any test unit. Test Unit 2 yielded the second-highest amount of debitage with 720 pieces. Test Units 1 , 4, and 6 all yielded fewer than 45 pieces. Test Unit 5 yielded by far the most bones with 712 specimens, while Test Unit 2 yielded 325 bones. Test Units 4 and 6 yielded fewer than 5 pieces of bone each. Mussel shells, the third most abundant material group, were mostly recovered from Test Units 3 and 5 (expanded units). Test Unit 5 yielded 350 shells, and Test Unit 3 contained 129. The remaining four test units each contained fewer than 50 shells.

The horizontal distribution of stone tools mimics this pattern, with Test Units 2,3 , and 5 yielding the majority of each tool type. Four of the 5 ( 80 percent) Perdiz points were from Test Unit 5, and 13 of the 21 ( 62 percent) bifaces were from Test Units 2, 3, and 5. The single uniface, 4 of the 5 (80 percent) utilized flakes, and 4 of the 7 (57 percent) ground and battered stone tools were from Test Units 2, 3, and 5. All five ceramic sherds were recovered from Test Unit 5. The artifact-rich central portion of the site was also the location of Features 2 and 3. Feature 1 was near the northern margin of the site in Test Unit 1.

As shown in Figure 4.1, the majority of the artifacts, features, and other cultural materials, along with all of the radiocarbon dates, are vertically distributed throughout the $\mathrm{Ab}$ soil horizon. Some cultural materials were recovered from above and below the $\mathrm{Ab}$ soil horizon, but they are relatively few in number compared to the numbers of materials recovered from the buried soil. As previously noted, this soil is present at similar stratigraphic and geomorphic positions throughout the lower North Bosque river valley, representing a valleywide stabilization of the floodplain beginning around 2,000 to 1,500 years ago. At several localities at the upper end of Waco Lake, bulk humates from the soil yielded radiocarbon ages of $690 \pm 70$ to $1720 \pm 60$ B.P. (Mehalchick and Kibler 2008:288; Scott et al. 2002). A coeval buried soil or paleosol in the Hog Creek valley (see Henry et al. 1980), which is part of the lower Bosque basin, suggests that floodplain stabilization and subsequent soil formation was a basinwide occurrence. Similar buried soils are also present throughout the lower Leon River basin to the south and southwest. At Fort Hood, the Leon River (Mehalchick et al. 1999:213-220; Mehalchick et al. 2000:197-200) and Tanktrail (Nordt 1995) paleosols represent a basin-wide occurrence of floodplain stabilization and soil formation at ca. 1300-1,000 B.P. Similar stratigraphic and geomorphic positions and contemporaneity are not the only features these soils share. All are cumulic soils that encapsulate archeological sites dating to the latter half of the Late Archaic and the Late Prehistoric periods. In many cases, the cumulic nature of these soils allows for the vertical separation of the multiple temporal components that are housed within them.

Chronological data for 41BQ285 include 5 radiocarbon dates (see Table 3.3), 5 Perdiz arrow points, a Godley-like and a Pedernales dart point, and 5 ceramic sherds. As shown in Figure 4.1, the five radiocarbon dates are in line 


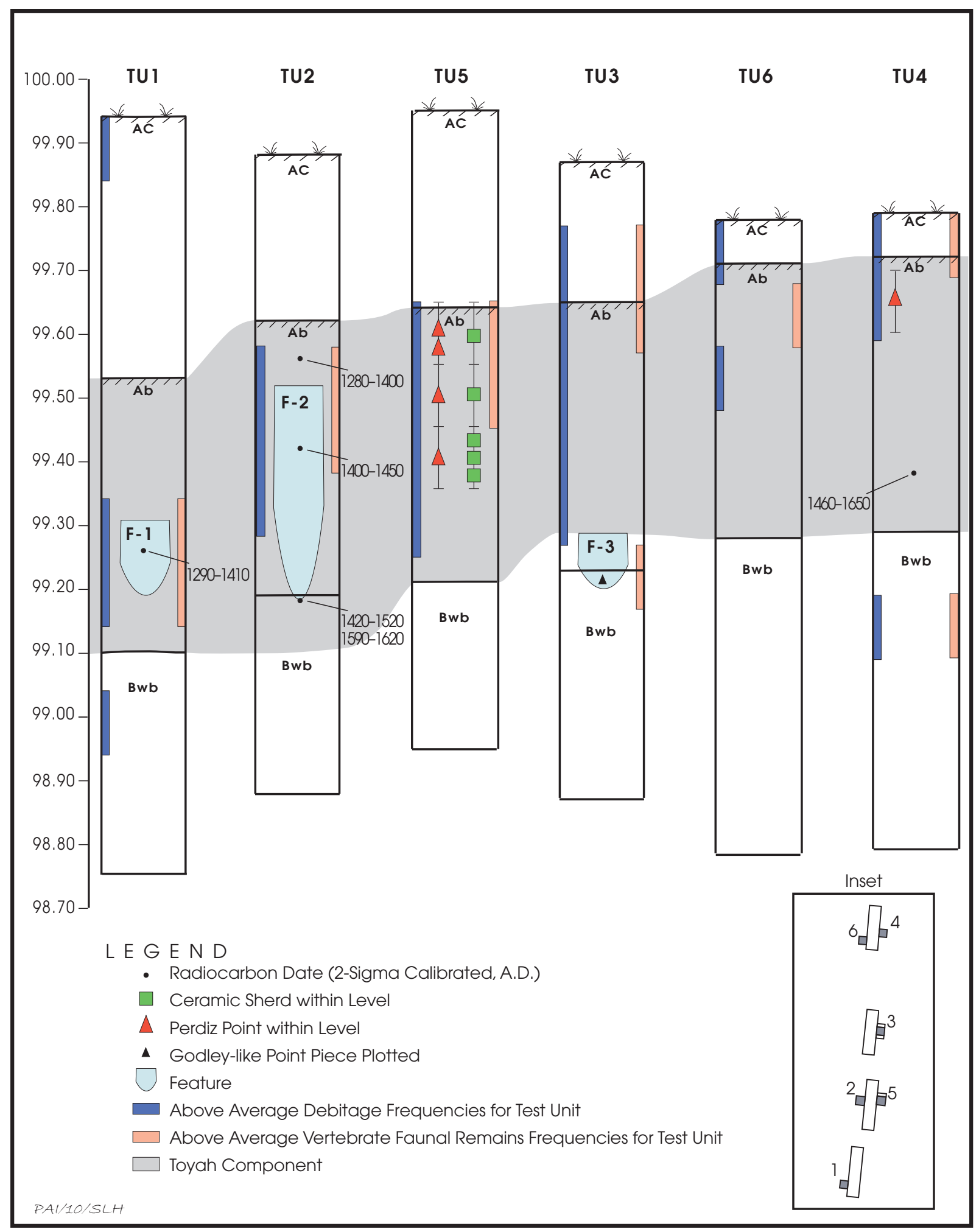

Figure 4.1. Vertical distribution of diagnostic artifacts, radiocarbon dates, and other select materials. 
with archeological expectations based on geoarcheology and the recovered material culture. However, the uppermost date in Test Unit 2 is older than the two dates for Feature 2 below it. This minor discrepancy is not particularly troublesome because Feature 3 is intrusive and the top of the feature may have actually been higher than was observable. It is also possible that the uppermost dated sample represents charcoal that was moved up-profile by bioturbation, which would not be unexpected in an active soil with dense vegetation.

All chronological evidence, absolute and relative, indicates the presence of Late Archaic and Late Prehistoric components, with the latter dating to Collins' (1995) Toyah interval. All of the recovered cultural materials are sorted into components in Table 4.1. The upper component, herein generically called the Toyah component, is dispersed vertically over $40 \mathrm{~cm}$, but is fairly well defined. In contrast, a small amount of cultural material above is not assigned to a component, and the lower Late Archaic component contains very sparse materials and is poorly defined. Table 4.2 is a summary of observations pertaining to the cultural components at 41BQ285.

\section{LATE ARCHAIC COMPONENT}

The Godley-like and Pedernales dart points are indicative of a Late Archaic occupation(s). Downstream from 41BQ285, Godley points were the most common point type found in Analytical Unit 1 at the Britton site and Analytical Unit 2 at the McMillan site (Mehalchick and Kibler 2008). These two analytical units were dated to $1890-1550$ B.P. and $1945-1180$ B.P. In the central Texas cultural chronology (Collins 1995; Johnson and Goode 1994; Prewitt 1981, 1985) Pedernales points date to ca. $3500-2600$ B.P. Slightly older radiocarbon dates have been obtained on Pedernales-associated contexts at such sites as Anthon below the southern margin of the Edwards Plateau (Goode 2002:201-202) and Bessie Kruze on the Blackland Prairie east the plateau (Johnson 2000:56-59).

The Pedernales point at 41BQ285 was recovered from loose sediments at the bottom of Backhoe Trench 5 soon after it was excavated. Its provenience is ambiguous and thus does not tell us much about other cultural materials that might be associated or the spatial context of a
Late Archaic Pedernales-age component. It is possible that the slight peaks in debitage and vertebrate faunal remains below the $\mathrm{Ab}$ soil horizon (see Figure 4.1) are associated with a Pedernales occupation of the site, but this notion is purely speculative.

The Godley-like point is associated with Feature 3, which is located near the base of the Ab soil horizon, a provenience or soil-stratigraphic position that is in agreement with the estimated age of this soil. What other cultural materials might be associated with the Godleylike point and Feature 3 (aside from a biface, one piece of bone, and three mussel shells) is not clear. Cultural materials recovered from the lower levels of the $\mathrm{Ab}$ horizon are either few in number or more clearly associated with the later Toyah component. Given these facts, little can be said about the Late Archaic component(s) other than that it is poorly defined in terms of its age, horizontal and vertical extent, and material contents.

\section{TOYAH COMPONENT}

Compared with the Late Archaic component, the Late Prehistoric component at 41BQ285 is better defined in terms of its age, extent, and associated materials. The radiocarbon dates and the ceramic sherds (although untyped) are indicative of the presence of a Late Prehistoric component, and the Perdiz arrow points suggest some affiliation with the Toyah phase or culture. The Toyah phase dates to ca. A.D. 1300-1700 across the Edwards Plateau and Llano Uplift and adjacent portions of the Gulf Coastal Plain, Rolling Plains, Cross Timbers, Grand Prairie, and Lampasas Cut Plain (see Arnn 2007, 2010; Johnson 1994; Kenmotsu and Boyd n.d.). The two-sigma calibrated dates for the five radiocarbon assays obtained for 41BQ285 span a temporal range of A.D. 1280 to 1650. Averaging the radiocarbon ages to produce a mean age for the component, although tempting, cannot be done because the ages are significantly different $\left(X^{2}=46.55, d f=4, P<0.01\right)$. This suggests that the component is comprised of more than one occupation during the Toyah interval, which is not surprising given that the artifacts and features are spread vertically over $40 \mathrm{~cm}$ within the cumulic soil. Although the radiocarbon dates indicate the presence of multiple occupations, more discrete temporal units or artifact and 


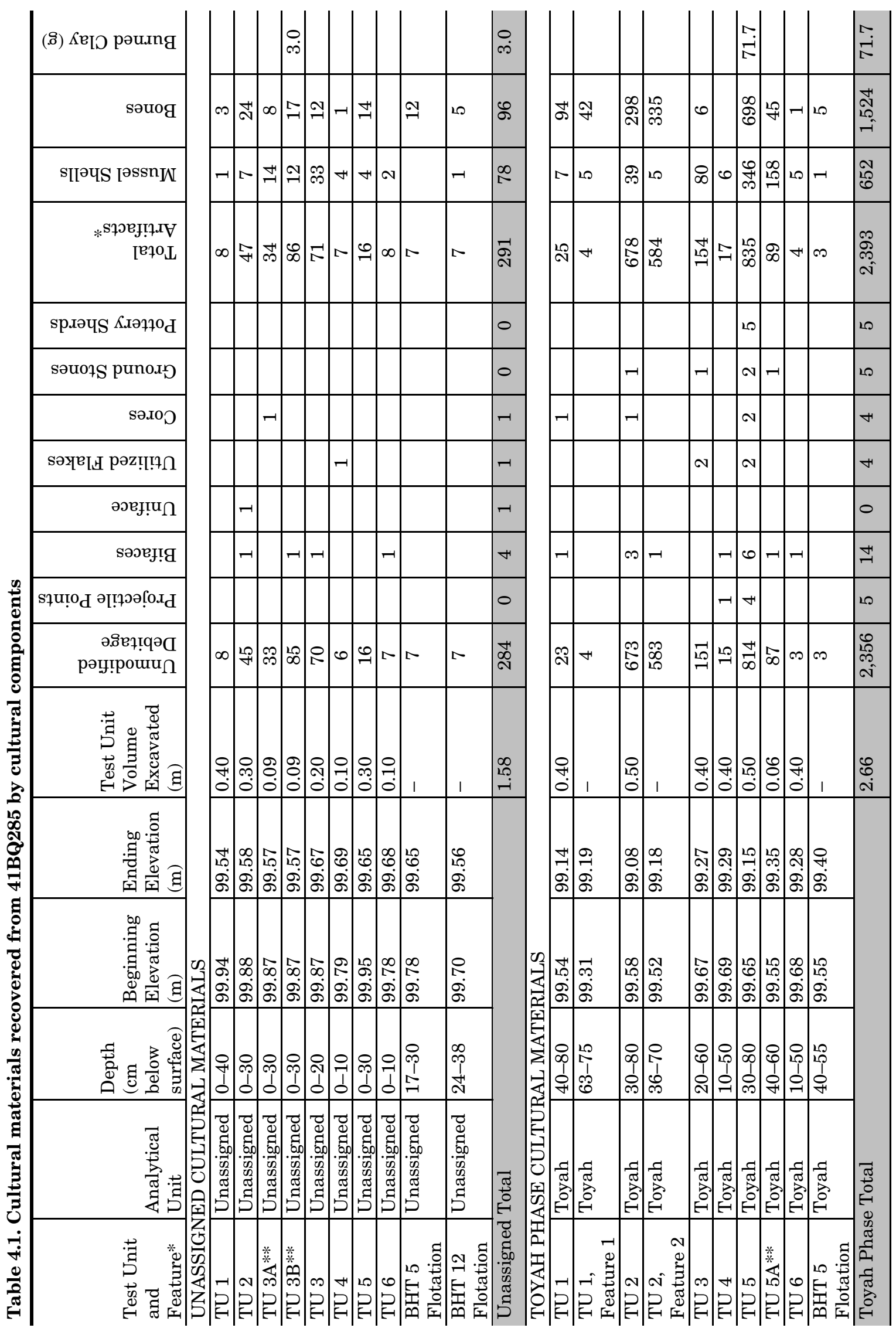




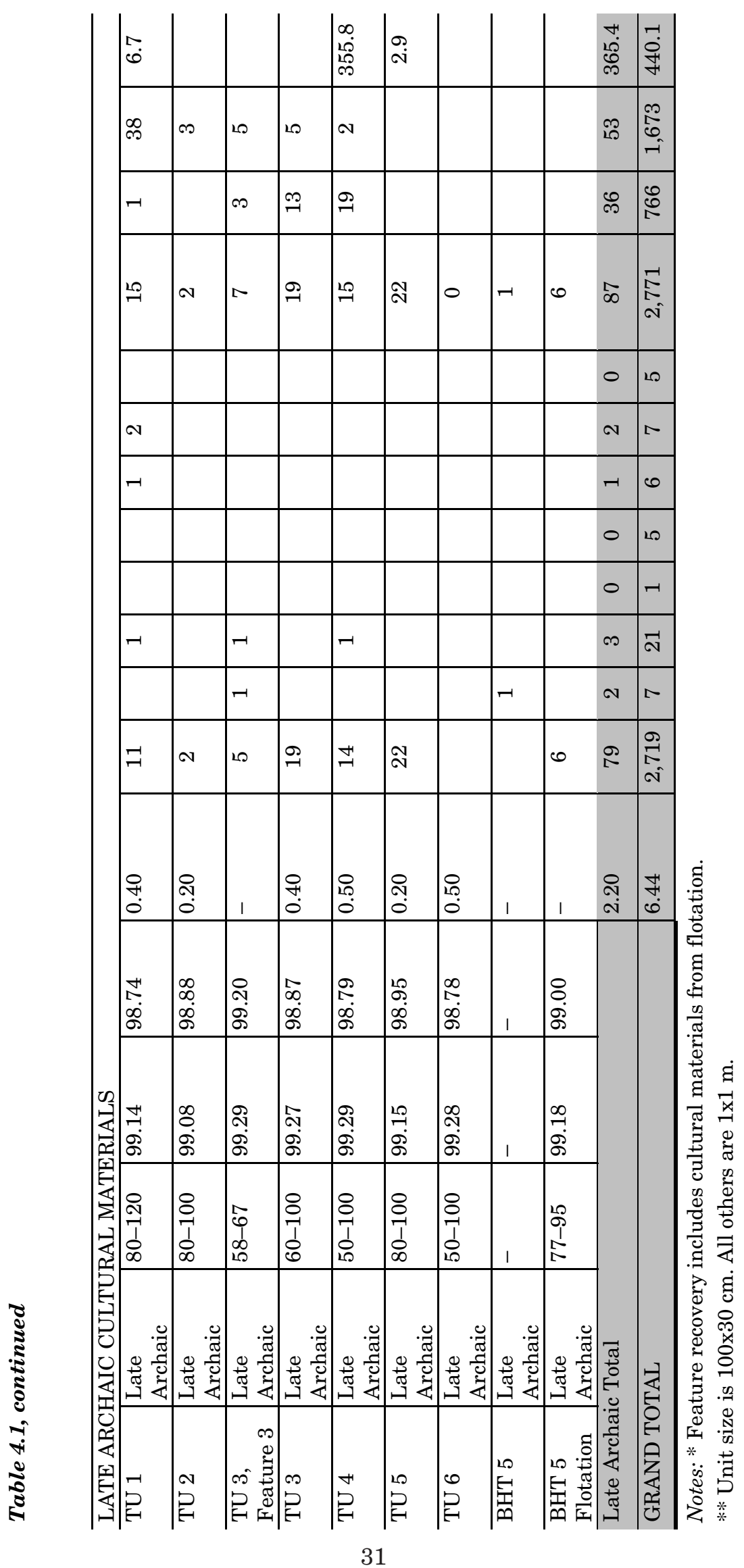


Table 4.2. Summary of cultural components defined at $41 B Q 285$

\begin{tabular}{|c|c|c|c|c|}
\hline \multirow[t]{9}{*}{ Site Data } & Component & Unassigned & $\begin{array}{l}\text { Late Prehistoric - Toyah } \\
\text { phase }\end{array}$ & Late Archaic \\
\hline & $\begin{array}{l}\text { Confidence } \\
\text { Level }\end{array}$ & $\begin{array}{l}\text { Low. Upper deposits } \\
\text { might be Toyah phase. }\end{array}$ & $\begin{array}{l}\text { Moderate. The component } \\
\text { is solid, but the upper } \\
\text { and lower boundaries are } \\
\text { fuzzy. }\end{array}$ & $\begin{array}{l}\text { Low. Component is poorly } \\
\text { defined. }\end{array}$ \\
\hline & Site Type & $\begin{array}{l}\text { Unknown because sample } \\
\text { is too small. }\end{array}$ & $\begin{array}{l}\text { Probably residential, but } \\
\text { sample is too small for } \\
\text { certainty. }\end{array}$ & $\begin{array}{l}\text { Unknown because sample } \\
\text { is too small. }\end{array}$ \\
\hline & $\begin{array}{l}\text { Total Hand } \\
\text { Excavation Area } \\
\left(\mathrm{m}^{2}\right)\end{array}$ & $6.6 \mathrm{~m}^{2}$ & $6.3 \mathrm{~m}^{2}$ & $6.0 \mathrm{~m}^{2}$ \\
\hline & \begin{tabular}{|l|} 
Total Hand \\
Excavation \\
Volume \\
$\left(\right.$ estimated $\left.\mathrm{m}^{3}\right)$ \\
\end{tabular} & $1.58 \mathrm{~m}^{3}$ & $2.66 \mathrm{~m}^{3}$ & $2.20 \mathrm{~m}^{3}$ \\
\hline & $\begin{array}{l}\text { Thickness } \\
\text { of Component } \\
\text { (estimated) }\end{array}$ & $\begin{array}{l}\text { Varies from } 10 \text { to } 50 \mathrm{~cm} \\
\text { thick. Average is about } \\
30 \mathrm{~cm} .\end{array}$ & $\begin{array}{l}\text { Varies } 45 \text { to } 60 \mathrm{~cm} \text { thick. } \\
\text { Average is about } 50 \mathrm{~cm} .\end{array}$ & $\begin{array}{l}\text { Unknown. Excavated } \\
\text { portions vary from } 10 \text { to } \\
50 \mathrm{~cm} \text { thick, but the } \\
\text { component continues } \\
\text { deeper. }\end{array}$ \\
\hline & $\begin{array}{l}\text { Stratigraphic } \\
\text { Association and } \\
\text { Elevation Range }\end{array}$ & $\begin{array}{l}\text { Starts at ground surface } \\
\text { and extends down to top } \\
\text { of Ab horizon between ca. } \\
99.70 \text { and } 99.50 \mathrm{~m} .\end{array}$ & $\begin{array}{l}\text { Starts at top of } \mathrm{Ab} \\
\text { horizon between } 99.70 \\
\text { and } 99.50 \mathrm{~m} \text {. Extends to } \\
\text { at or near } \mathrm{Ab} / \mathrm{Bwb} \text { contact } \\
\text { between } 99.25 \text { and } \\
99.10 \mathrm{~m} \text {. } \\
\end{array}$ & $\begin{array}{l}\text { Starts at or near } \mathrm{Ab} / \mathrm{Bwb} \\
\text { contact between } 99.25 \\
\text { and } 99.10 \mathrm{~m} . \text { Extends to } \\
\text { bottom of excavation } \\
\text { units as deep as } 98.74 \mathrm{~m} \text {. }\end{array}$ \\
\hline & $\begin{array}{l}\text { Radiocarbon } \\
\text { Dates }\end{array}$ & 0 & 5 & 0 \\
\hline & $\begin{array}{l}\text { Associated } \\
\text { Features }\end{array}$ & None & $\begin{array}{l}\text { One bone and burned } \\
\text { rock cluster of unknown } \\
\text { function (Feature } 1 \text { ). One } \\
\text { rock-lined basin hearth } \\
\text { (Feature } 2) .\end{array}$ & $\begin{array}{l}\text { One rock-lined basin } \\
\text { hearth (Feature } 3 \text { ). } \\
\text { Association with } \\
\text { component is based on } \\
\text { dart point occurrence. } \\
\end{array}$ \\
\hline \multirow[t]{10}{*}{$\begin{array}{l}\text { Material } \\
\text { Culture }\end{array}$} & $\begin{array}{l}\text { Perdiz Arrow } \\
\text { Points } \\
\end{array}$ & 0 & 5 & 0 \\
\hline & $\begin{array}{l}\text { Godley-Like } \\
\text { Dart Point } \\
\end{array}$ & 0 & 0 & 1 \\
\hline & \begin{tabular}{|l|} 
Pedernales Dart \\
Point \\
\end{tabular} & 0 & 0 & 1 \\
\hline & \begin{tabular}{|l|} 
Ceramic Sherds \\
\end{tabular} & 0 & 5 & 0 \\
\hline & $\begin{array}{l}\text { Other Chipped } \\
\text { Lithic Tools } \\
\end{array}$ & 6 & 28 & 3 \\
\hline & \begin{tabular}{|l|} 
Cores \\
\end{tabular} & 1 & 4 & 1 \\
\hline & \begin{tabular}{|l|} 
Unmodified \\
Debitage \\
\end{tabular} & 284 & 2,356 & 79 \\
\hline & $\begin{array}{l}\text { Ground Stone } \\
\text { Tools } \\
\end{array}$ & 0 & 5 & 2 \\
\hline & \begin{tabular}{|l|} 
Mussel Shells \\
\end{tabular} & 78 & 652 & 36 \\
\hline & Exotic Artifacts & none & $\begin{array}{l}\text { Caddoan-style decorated } \\
\text { sherds, but could be } \\
\text { locally made. }\end{array}$ & none \\
\hline
\end{tabular}


Table 4.2, continued

\begin{tabular}{|c|c|c|c|c|}
\hline \multirow[t]{7}{*}{$\begin{array}{l}\text { Vertebrate } \\
\text { Faunal } \\
\text { Remains }\end{array}$} & $\begin{array}{l}\text { Identified } \\
\text { Animals* }\end{array}$ & Deer, turtle, large bird & $\begin{array}{l}\text { Deer, turtle, turkey, large } \\
\text { bird, cottontail rabbit, } \\
\text { medium rodent, raccoon, } \\
\text { snake, lizard, gar }\end{array}$ & Deer, turtle \\
\hline & Total Bones & 96 & 1,524 & 53 \\
\hline & Spiral Fracture & 19 & 377 & 9 \\
\hline & \begin{tabular}{|l|} 
Angular \\
Fracture
\end{tabular} & 74 & 1,120 & 44 \\
\hline & Unbroken & 3 & 27 & 0 \\
\hline & \begin{tabular}{|l|} 
Charred or \\
Calcined Bones
\end{tabular} & 25 & 367 & 5 \\
\hline & $\begin{array}{l}\text { Bones with Cut } \\
\text { Marks }\end{array}$ & 0 & 1 & 0 \\
\hline \multirow[t]{2}{*}{$\begin{array}{l}\text { Macro- } \\
\text { botanical } \\
\text { Remains }\end{array}$} & $\begin{array}{l}\text { Charred Woods } \\
\text { (from flotation) }\end{array}$ & none & $\begin{array}{l}\text { Features } 1 \text { and } 2 \\
\text { produced white oak, red } \\
\text { oak, oak, elm, hackberry, } \\
\text { hackberry/elm, willow, } \\
\text { willow/cottonwood, ash, } \\
\text { sycamore, } \\
\text { possumhaw/yaupon, and } \\
\text { pecan/hickory. }\end{array}$ & none \\
\hline & $\begin{array}{l}\text { Charred Seeds } \\
\text { and Fruits (from } \\
\text { flotation) }\end{array}$ & none & $\begin{array}{l}\text { Features } 1 \text { and } 2 \\
\text { produced seeds of } \\
\text { cleavers, chenopodium, } \\
\text { elderberry, pokeweed, } \\
\text { and little barley, along } \\
\text { with gourd rind. }\end{array}$ & none \\
\hline \multirow{5}{*}{$\begin{array}{l}\text { Density of } \\
\text { Diagnostic } \\
\text { Artifacts }\end{array}$} & Perdiz Points & $\mathrm{n} / \mathrm{a}$ & $0.79{\text { per } \mathrm{m}^{3}}^{3}$ & $\mathrm{n} / \mathrm{a}$ \\
\hline & $\begin{array}{l}\text { Chipped Stone } \\
\text { Tools }\end{array}$ & 0.9 per $\mathrm{m}^{3}$ & 4.4 per $\mathrm{m}^{3}$ & 0.5 per $\mathrm{m}^{3}$ \\
\hline & $\begin{array}{l}\text { Unmodified } \\
\text { Debitage }\end{array}$ & 179.7 per $\mathrm{m}^{3}$ & $885.7{\text { per } \mathrm{m}^{3}}^{2}$ & 35.9 per $\mathrm{m}^{3}$ \\
\hline & Ceramic Sherds & $\mathrm{n} / \mathrm{a}$ & $0.79{\text { per } \mathrm{m}^{3}}^{3}$ & $\mathrm{n} / \mathrm{a}$ \\
\hline & Bones & $60.8{\text { per } \mathrm{m}^{3}}^{3}$ & 572.9 per $^{3}$ & $24.1{\text { per } \mathrm{m}^{3}}^{3}$ \\
\hline
\end{tabular}

* Excludes intrusive species (e.g., armadillo) and unidentified mammal bones of all sizes (small, medium, and large). The minimum number of individuals for each identified animal is 1, except for deer with an MNI of 3 .

feature assemblages cannot be delineated within the Toyah component. First and foremost, there are minor internal inconsistencies with the suite of radiocarbon dates (see Figure 4.1). Second, while the Ab soil is cumulic in nature, sedimentation rates were not fast enough to provide significant vertical separation of materials from a series of occupations that occurred over a relatively short time span of less than 400 years. Despite the fact that more discrete temporal units cannot be delineated within the upper component, it is fairly clear that the bulk of the cultural materials recovered from the $\mathrm{Ab}$ soil horizon are from the Toyah interval.
Based on the presence of numerous Perdiz points, we consider the upper component to represent a Toyah phase or Toyah-like occupation, although exactly what this means is discussed later. The artifacts, features, and other cultural materials associated with the Toyah component suggest the site was occupied multiple times as a small open campsite beginning around the end of the thirteenth century to the middle of the seventeenth century A.D. The people who occupied the site exploited various local resources while camped there, chief among them deer. At least three deer were killed nearby and processed and consumed at the site. Recovered deer and 
deer-sized artiodactyl and mammalian skeletal elements are highly fragmented, indicating that marrow extraction and probably bone grease processing occurred. Bone grease production is often viewed as a high-cost strategy employed during times of starvation or resource scarcity (e.g., Binford 1978; Nagaoka 2005). Mehalchick and Kibler (2008:348), however, disagree with this assumption. In light of the potential calorie and protein yields, they believe that grease production was actually a low-cost endeavor (search and capture costs are paid for by meat and marrow yields) and simply represents an efficient use of the animal. Some of the ground and battered quartzite tools associated with this component may have been used for crushing the bone in the grease producing process. Based on findings at the Rush site (41TG346) in Tom Green County, Quigg (1997) believes that some Toyah peoples produced bone grease in order to make pemmican, not as a starvation food but as an important staple that preserved well, was easily transported, and highly nutritious.

Other local food sources exploited by the Toyah hunters and gatherers at 41BQ285 included small mammals, turtles, birds, and freshwater mussels. Of these fauna, mussels were most common. Mussel shells and valves at 41BQ285 are relatively numerous but small, suggesting that they were intensively collected. Although intensively exploited, mussels are nutritionally poor in terms of calories from protein and fat. Based on these facts, and on archeological investigations at the Britton, McMillan, and Higginbotham sites downstream from 41BQ285, Mehalchick and Kibler (2008:350) suggested that the use of nutritionally poor mussels was offset by ease of availability and collection and that small numbers were collected daily simply to augment family meals.

Charred plant food remains, recovered from Features 1 and 2, include nutshell and nutmeat fragments of pecan and acorn (see Appendix B). Five genera or species of carbonized seeds and one fruit rind were also recovered from the features. The seed specimens consist of cleavers (Galium spp.), chenopodium (Chenopodium spp.), elderberry (Sambucus nigra), pokeweed (Phytolacca americana), and little barley (Hordeum pusillum) seeds. All but the cleavers seeds are known sources of food. The fruit rind is that of a nondomesticated variety of gourd (cf. $\mathrm{Cu}$ curbita texana).
Other charred macrobotanical remains recovered from Features 1 and 2 represent fuel wood or firewood. Identification was attempted for 135 pieces of wood charcoal, of which 130 were identified to the family level or better. Nearly half (47 percent) of the identified specimens are oak (Quercus sp.), and both white and red oaks are represented. Oaks are natural pruners, frequently dropping branches and providing considerable amounts of dead limb wood for firewood collectors, so it not surprising that they are the dominant taxa in the charred wood assemblage. Elm and hackberry represent a little more than one-third (34 percent) of the identified charred wood assemblage. The remaining identifiable specimens consist of willow, cottonwood, ash, sycamore, possumhaw or yaupon, and pecan or hickory. Depending on the species of oak, all of the identified taxa in the charred wood assemblage commonly occur in riparian settings in central Texas. Because the wood used for fires was local to the site, it suggests that accessible dead limb probably was not depleted while the site was occupied and that the Toyah interval occupations were relatively short term.

Chert, used for the production of tools and weapons, was another local resource used by the Late Prehistoric peoples at 41BQ285. Many of the cherts represented in the 41BQ285 chipped stone assemblage are macroscopically similar to primary and secondary chert sources identified throughout the lower Bosque basin by Mehalchick and Kibler (2008:352-356). Cherts from these sources are remarkably similar visually (various shades of gray) and fairly distinct with white, bluish white, and light bluish gray microfossils. These distinctive cherts are described and illustrated by Mehalchick and Kibler 2008:Figure 9.4; 352-356). A primary source of these cherts is ca. $0.7 \mathrm{~km}$ north of the site along the valley wall of the North Bosque (Locality 12a in Mehalchick and Kibler 2008:352-356), and a secondary source is located just below 41BQ285 in the North Bosque River channel (Locality $12 \mathrm{~b}$ in Mehalchick and Kibler 2008:352-356).

Although substantial chert sources are nearby, the artifacts and debitage in the 41BQ285 Late Prehistoric component suggest that decortication and early-stage reduction of raw materials occurred offsite. Bifacial tools dominated the tool kits, and late-stage biface reduction and biface edge maintenance (resharpening) were two of the more common 
activities that occurred onsite. The small number of utilized flakes and unifacial tools indicate that most onsite tasks were probably completed with more formal bifacial toolsanother indication that the occupations may have been relatively short.

Along with the chipped and ground and battered stone tools, the five ceramic sherds represent at least three different vessels, presumably small cooking jars and bowls. Although typological identifications were not possible based on the small sherds, it was originally thought that some of the sherds represented Caddo vessels manufactured in east Texas based on their decorative elements and motifs, particularly the one engraved sherd from a carinated bowl. Subsequent petrographic and instrumental neutron activation analyses, however, indicate that none of the sherds represent jars and bowls of east Texas origin. Other Toyah or Toyah-like sites in the region-such as the Kyle Rockshelter (Jelks 1962) and Jayroe site (Kibler and Broehm 2005), have yielded sherds that look like Caddo pottery, and Perttula et al. (2003) report that decorated pottery sherds from many sites have been chemically identified as being made by the Caddo in East Texas. However, the Caddo-like pottery from 41BQ285 is a mystery. The geochemical analysis strongly suggests that the $41 \mathrm{BQ} 285$ sherds were not manufactured in east Texas and may have been made locally or somewhere in the general area of the site. This finding is somewhat surprising and has important implications for understanding the Late Prehistoric Toyah phenomenon in the northeastern portion of central Texas. As is discussed below, this adds an interesting dynamic to the Late Prehistoric social interactions of the middle Brazos River valley.

\section{WHAT IS THE "TOYAH" COMPONENT AT 41BQ285?}

Although the upper component at 41BQ285 is referred to in this report as Toyah or Toyahlike, in light of the artifacts recovered, it may be more precise to simply state that this site dates to the Toyah interval or Late Prehistoric II period rather than assigning it to an archeological culture. This issue warrants some consideration in light of the volume of archeological discourse on Toyah over the past two decades (e.g., Arnn 2007; Black et al. 1997; Collins 1995; Johnson
1994; Karbula 2003; Kenmotsu 2001; Kenmostu and Wade 2002; Mauldin 2003; Mehalchick et al. 1999; Pertulla et al. 2003; Quigg 1997; Quigg and Peck 1995; Ricklis 1992, 1994, 1995; Shafer 2006; Story 1990; Treece et al. 1993; Wade 2001, 2003), including two very recent books devoted entirely to the topic (Arnn 2010; Kenmotsu and Boyd n.d.). More specifically, we consider the following two questions. First, how closely does 41BQ285 resemble the model for a Classic Toyah site? And second, how does 41BQ285 fit into current anthropological models of social identity and interaction for the Late Prehistoric period in Texas?

It must be stated up front that both of these questions are beyond the scope of the excavations conducted for the Toyah component at 41BQ285. This assessment is based on two primary factors: the limited area of archeological exploration and the relatively low density of the cultural materials recovered, both of which result in an archeological sample that is inadequate for supporting robust interpretations. This investigation was confined to a small sliver (only 4 to $6 \mathrm{~m}$ wide) of state-owned highway right of way. Thus, only a small sample of what is almost certainly a large site was excavated (see Figure 2.1). Hand excavations in this component comprised only 6.3 $\mathrm{m}^{2}$ in area and removed only $2.7 \mathrm{~m}^{3}$ of fill. They revealed only two cultural features and yielded a meager assemblage that includes only 5 pottery sherds, 33 chipped stone tools (including 5 Perdiz points), and 5 ground and battered stone tools. Given that the frequency of all chipped stone tools is 5.2 specimens per square meter, obtaining a small but statistically valid sample of 200 stone tools for the Toyah interval component would have required an excavation sample of $38.5 \mathrm{~m}^{2}$, which is more than six times larger than the area actually excavated. Therefore, it is acknowledged that the sample size, both in terms of the area examined and the quantity of materials recovered, is simply too small to support anything more than broad interpretations of human activities at this location. For example, it is impossible to know from the current sample exactly what the upper component within the tested portion of 41BQ285 represents. Does it represent general domestic activities within a residential base, specialized activities within a residential base, a low-density area on the margins of a residential base, or some type of highly specialized activity site? 
Despite the limited excavation and minimal archeological data derived from this investigation, it is important to remember that there is little doubt that 41BQ285 extends beyond the FM 56 right of way. In fact, given its location along the North Bosque River, it is likely that the $41 \mathrm{BQ} 285$ is a fairly large site that contains buried cultural deposits over a very large area. The upper Toyah interval component may extend well beyond the highway right of way, and these occupations could represent a variety of domestic and specialized activities associated with repeated occupations at a large residential base camp. The entire site probably has a high research potential. Consequently, the two issues presented above do indeed apply in a general sense to all of 41BQ285 even though we do not know much about the entire site.

\section{Is 41BQ285 Classic Toyah?}

Archeologists have been studying the Toyah phenomenon since the 1930s (see Kelley et al. 1940), and there is now a substantial number of excavated sites that contribute to our knowledge of Toyah (see Kenmotsu and Boyd n.d.:Figure 1 and Table 1). However, Toyah remained a somewhat fuzzy concept until LeRoy Johnson's (1994) seminal study provided a more concrete definition. Based on an examination of the archeological data from the Buckhollow site (41KM16), along with a thoughtful review of well-reported archeological data from a reasonable sample of similar sites, Johnson (1994:243, Figure 105) identified the homeland for what he called the "Classic Toyah" culture. But at the same time, he acknowledged that Toyah people were not alone on the landscape. Surrounding the Classic Toyah area, Johnson identified a marginal zone that he called a "shared area." He noted that there are numerous sites within this shared area that contain some, but not all, of the key elements that define Classic Toyah material culture. When combined, the Classic Toyah core and shared area comprise what might be called the Greater Toyah region.

Most current archeological researchers have adopted Johnson's (1994) concept of a Classic Toyah culture area surrounded by a buffer zone where Toyah peoples interacted with other cultures (e.g., Arnn 2007; Kenmotsu and Boyd n.d.; Kenmotsu and Wade 2002; Mehalchick et al. 1999). This is indeed an important concept for studying the Toyah phenomenon found over much of Texas. As shown in Figure 4.2, 41BQ285 is located on the northeastern edge of Johnson's Classic Toyah area, and it is adjacent to the shared area near the Balcones Escarpment. Johnson (1994) identifies the diagnostic material culture of Classic Toyah to include Perdiz arrow points, Harahey (beveled) knives, end scrapers (the distinctive hafted Plains-style tools), and bone-tempered plain pottery (a.k.a. Leon Plain). The Perdiz points, beveled knives, and end scrapers are considered to be the Classic Toyah tool kit that reflects killing, skinning, and hide processing of large animals, with bison and deer being particularly important game animals in the Classic Toyah area. Johnson defined the Classic Toyah area based on the distinctiveness of its material culture, but he specifically notes that there is considerable variation in the material culture recovered at sites around the edges of the classic area. Notably, Johnson (1994:265-271) recognized the variability in material culture seen across the state and attributes it to Toyah "regionalism."

For several decades, Toyah has been discussed as a cultural "phase" following the concept as it was defined by Willey and Phillips (1958:21-29, 48-57). While Willey and Phillips acknowledged there might be some degree of correlation between an archeological phase and a "society," they explicitly stated that a phase did not necessarily reflect social reality (see Willey and Phillips 1958:50-51). Although Willey and Phillips never stated, or even implied, that a phase must represent a single or specific social group, researchers often conceptualize archeological phases in this manner. Through time, Texas archeologists have expanded the geographic extent of the Toyah phase based on new finds of Toyah material culture. The expansion continued to the point that the Toyah phase now encompasses a vast portion of the area we call Texas.

There is abundant ethnographic evidence and anthropological theory suggesting that single groups of hunter-gatherer peoples rarely inhabited such a large area, yet this is still a prevailing view of Toyah. Rather than thinking about Toyah as a culture or phase, Arnn (2007, 2010) suggests that it would be more productive to view the Toyah phenomenon using the anthropological concepts of communities and social fields as described by Lesser (1961) and 


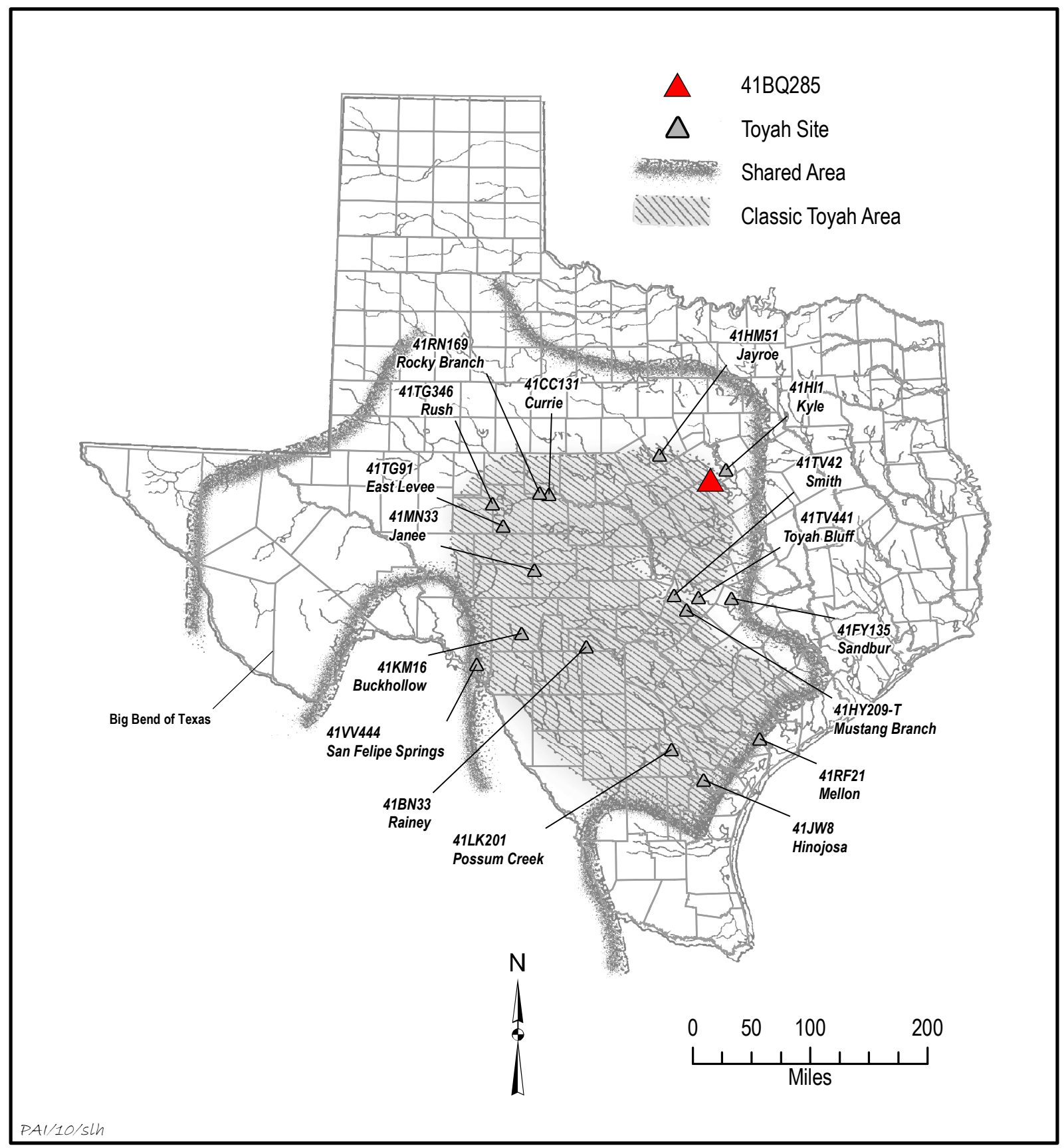

Figure 4.2. Location of 41BQ285 in relation to the Classic Toyah area and selected Toyah sites. Based map is from Kenmotsu and Boyd (n.d.) with Toyah areas adapted from Johnson (1994:Figure 105).

Welsch and Terrell (1998). Arnn conceptualizes Toyah as a large regional network or social field comprised of several marriage/culture groups that in turn consist of multiple distinct communities that operate at a local level. Social fields may be viewed as interaction spheres or exchange networks, while communities approximate the small groups that anthropologists call bands (Arnn 2007:12-24; 2010:Chapter 8). From this perspective, the concept of a single, geographically widespread Toyah culture or phase becomes irrelevant. The more fruitful approach 
to understanding the Late Prehistoric sociocultural identity and interaction is to examine the Toyah phenomenon in such a way that we may begin to recognize distinct communities, groups of related communities that functioned as marriage groups, and the larger social interaction that encompass many different communities.

The idea of a Toyah phase, a.k.a. Willey and Phillips (1958), may well be a case where our "normative constructs get in the way of understanding prehistory" (Scott Pletka, personal communication 2010). But Johnson's (1994:265-271) concept of Toyah regionalism fits nicely into a revised paradigm of communities, marriage/culture groups, and regional social fields. The variability in Toyah material culture across a vast landscape represents, in all likelihood, intentional ways of displaying the sociocultural identity of marriage/linguistic/ culture groups represented by clusters of communities that participated to varying degrees in a broad regional social field. As such, Toyah as a regional phenomenon represents one social field comprised of numerous marriage/linguistic/ culture groups that are themselves represented by multiple communities. Within this theoretical framework, recognizing distributional, stylistic, and technological differences in contemporaneous assemblages from one area within the Toyah region/social field to the next is of critical importance in distinguishing marriage/linguistic/ culture groups.

Returning to the issues presented earlier, although the current archeological evidence is not sufficient to support a determination of whether 41BQ285 represents a Classic Toyah site, some models or scenarios may be offered with the explicit acknowledgement that these are simply educated guesses. Based solely on its location, one might infer that if 41BQ285 is indeed a residential base, it would likely represent one of several seasonal sites occupied within the territorial range of a community/band that participated in varying degrees in a broader network or field of social interaction (i.e., Toyah). This inference is entirely consistent with Arnn's (2007) model as well as more generally accepted anthropological and archeological concepts (Binford 1980, Kelly 1995, Wobst 1974, and Yellen 1977). Applying this line of reasoning further, it also is likely that this community/band is a constituent element of a larger marriage/linguistic/culture group that deposited very similar, if not identical, material culture (due to similar environment conditions, intermarriage, etc.) within a geographically circumscribed area (also consistent with Arnn 2007, Binford 1980, Kelly 1995, Wobst 1974, and Yellen 1977). Therefore, the issue presented here is recognizing and acknowledging similarity and/or difference at various scales or dimensions of interaction.

Moreover, 41BQ285 is rather unusual in that, despite the admittedly small sample recovered, this site presents at least two or more different cultural influences. The first influence is in the form of Perdiz arrow points, which are a hallmark of the Toyah lithic assemblage. This is not altogether surprising since Toyah is by far the most widespread lithic assemblage seen in this region during this time period, and 41BQ285 is located along the edge of the Classic Toyah area defined by Johnson (1994). However, the second cultural influence observed at 41BQ285 is apparently Caddoan in the form of five ceramic sherds consisting of 2 plain, 2 fingernail punctate, and one engraved sherd, all decidedly non-Toyah in composition and appearance (i.e., they are unlike typical bone-tempered Toyah wares). Indeed, the engraved sherd is from a carinated bowl and is decidedly Caddoan in appearance. Therefore, another inference that can be made concerning $41 \mathrm{BQ} 285$ is that it represents an extension of Caddo influence into the Grand Prairie and Lampasas Cut Plain, as suggested by Story (1990:364) and Shafer (2006).

However, when the 41BQ285 sherds were subjected to geochemical and mineralogical sourcing analyses using petrography and INAA, not all of the results were as expected. The petrographic data seem to indicate that the engraved sherd could be from a Caddo vessel made in east Texas while the other four sherds were probably made locally. The INAA data seem to indicate that the plain and fingernail punctate sherds are probably locally made (at least one and the chemical signature of the engraved sherd does not match the chemistry of any Caddo pottery from east Texas (which includes a very large comparative data set for the entire region). Thus, another inference might be that the people who occupied 41BQ285 during the Toyah interval used some (and perhaps all) of the Toyah lithic technology in conjunction with Caddo ceramic technology, but were themselves a distinct group within a broad field of social interaction. 


\section{Sociocultural Identity at 41BQ285}

Going beyond the general concept of a Classic Toyah social field, it is worth considering how 41BQ285 might fit into the current models of sociocultural identity and interaction for the Late Prehistoric period in Texas. The North Bosque River is within the middle Brazos River drainage basin, a region that has yielded many vessels that display Caddo-style decorations at Late Prehistoric sites such as the Chupek (also spelled Chupik) (Watt 1941, 1953) and Asa Warner (Turner 1997; Watt 1956). In addition, Pertulla et al. (2003) conducted a geochemical study of sherds from several Late Prehistoric sites in the region (i.e., Penny Winkle, McDonald, Chupek [also spelled Chupik], Asa Warner, Barker, Rowe Valley, and several sites on Fort Hood), and the data confirm that pottery vessels with Caddo-style designs and decorations were indeed manufactured in east Texas by the Caddo and imported into the middle Brazos River valley.

The mechanisms that brought these vessels to the middle Brazos River valley are not clearly understood, but it is evident that the social identities of the Late Prehistoric peoples in this region are rather complex. In summarizing the Late Prehistoric period in central Texas, Story (1990:364) states that:

...the Austin phase dates from ca A.D. 700 or 800 to 1300 , the Toyah phase dates from ca 1300 to 1600 . However, it is becoming increasingly apparent that these phases represent more than one sociocultural unit. They hence are more appropriate as horizons or broad cultural patterns (e.g., Hester et al. 1989:32). In addition, there is evidence in the middle Brazos River basin of an intermediate period or horizon, an interval similar to the middle temporal phase in the Joe Pool and Richland Creek areas.... However, either because these sites have not been analyzed in detail (i.e., Chupik and Asa Warner) or the middle temporal phase remains have not been recognized as distinct, little is known about settlement/ subsistence patterns, mortuary behavior, or the nature of the Caddoan connections. Do these middle phase settlements on both the Brazos and Trinity rivers represent (1) groups from the east who occupied the area year around and/or seasonally; or (2) local groups who were interacting with Caddoans through trade, marriage, and visitations (Brown et al. 1987:38, 109-110)?

Story argued that this middle archeological period or horizon is characterized by Alba arrow points and early Caddo pottery in the middle Brazos River valley, but she did not elaborate further on the complex cultural dynamics that might have produced the archeological patterns.

More recently, Shafer (2006) has developed this idea into the "Prairie Caddo" model (Figure 4.3). He suggests that groups in the middle Brazos River valley between A.D. 1000 and 1300 were Caddo peoples who served as the sustaining population for the ceremonial center at the George C. Davis site. The basis for Shafer's model is the lack of contemporaneous habitation sites near the Davis site and the occurrence of a suite of artifacts at certain sites in the middle Brazos River valley (e.g., Chupek and Asa Warner) that are viewed as the material culture of ethnic Caddo groups. This diagnostic Prairie Caddo artifact assemblage includes Caddo ceramic vessels similar to those found at the Davis site, Alba and Bonham arrow points, Gahagan knives, and bone needles and metapodial beamers used for the manufacture of deer hide clothes. Artifacts within this assemblage (except beamers) occur at the Davis site in burial and nonburial contexts (Shafer 1973; Story 1972), and Shafer (2006) shows that these items are common at sites in the middle Brazos River valley, although they do not always occur together.

The geochemistry data for the 41BQ285 sherds strongly suggest that the pottery, including one engraved sherd from a carinated bowl, was made at or near the site rather than by the Caddo in east Texas. This evidence seems to support the Prairie Caddo model, although the Late Prehistoric component at 41BQ285 largely postdates Shafer's (2006) Prairie Caddo time period (A.D. 1000-1300), as well as Story's (1990) intermediate Late Prehistoric period. One must acknowledge the possibility that 41BQ285 could represent some type of late variant of the Prairie Caddo. It must also be noted that the artifact assemblage from 41BQ285 lacks the other 


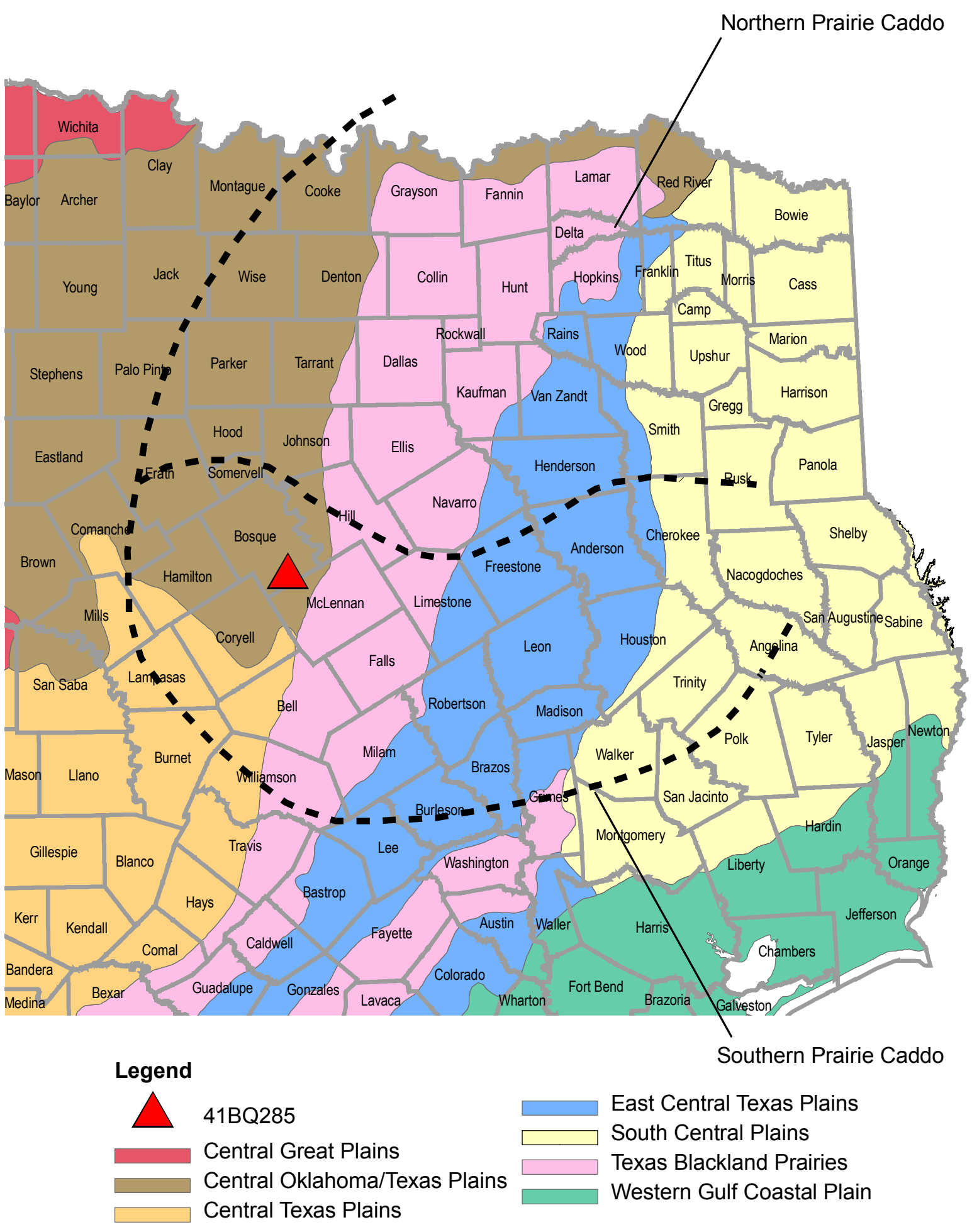

Figure 4.3. Map showing location of 41BQ285 relative to Shafer's (2006) proposed northern and southern Prairie Caddo areas and ecological regions in northeast Texas. Map is reproduced from Shafer (2006:Figure 1). Ecoregion base data are from Omernik (2003). 
diagnostic artifacts (e.g., Alba arrow points, bone needles, Gahagan knives, and beamers) that characterize Shafer's Prairie Caddo model and
Story's intermediate Late Prehistoric period, but this may reflect inadequate sampling rather than cultural reality. 



\section{SUMMARY AND ASSESSMENT OF 41BQ285}

\section{5}

Hand excavations at 41BQ285 consisted of six test units totaling $6.6 \mathrm{~m}^{2}$ of area and removed $6.4 \mathrm{~m}^{3}$ of fill (see Figure 2.1 and Table 4.1). The excavations yielded a moderate amount of cultural materials including seven projectile points, three burned rock features, a small number of bifacial tools, five pottery sherds, and sizable assemblages of unmodified debitage, vertebrate faunal remains, and freshwater mussel shells. Temporally diagnostic artifacts (Godley-like and Pedernales dart points, Perdiz arrow points, and pottery sherds) indicate that the site was occupied during the Late Archaic and Late Prehistoric periods. Except for the Pedernales dart point (found out of context in a backhoe trench), these diagnostic artifacts were recovered from known contexts within a buried cumulic Ab soil horizon. Soils of similar age and geomorphic position are documented downstream from 41BQ285, above Waco Lake, and in adjacent drainage basins such as the Leon River. The soils denote a period of floodplain stabilization and soil formation at ca. 1300-1,000 B.P. throughout the Bosque River Basin, and they also contain Late Archaic and Late Prehistoric cultural materials (Mehalchick et al. 1999; Mehalchick and Kibler 2008; Scott et al. 2002).

Providing a little more chronological clarity are five radiocarbon ages, three from features and two from nonfeature contexts. The dates fall between A.D. 1280 and 1650 and, in conjunction with the Perdiz points and pottery sherds, indicate that most of the materials recovered at the site belong to a Late Prehistoric component. The Late Archaic component at 41BQ285 represents a minor occupation compared to the Late Prehistoric component, and very little can be said about this earlier component. In contrast, the Late Prehistoric cultural remains clearly date to the Toyah interval and indicate a focus on the exploitation and use of local resources during a series of relatively short occupations. Activities included probable raw material procurement from nearby sources, late-stage biface reduction and tool production, and tool maintenance (resharpening). Other site activities focused on deer hunting, with deer carcasses being intensively processed to obtain marrow and probably bone grease. Other exploited fauna included small mammals, turtles, birds, and freshwater mussels. Foodstuffs were probably processed and prepared using bifacial tools, ground and battered stone tools, rock-lined cooking basins, and ceramic jars and bowls. A geochemical analysis of the pottery produced unexpected results, indicating that the Caddo in east Texas did not manufacture the pottery sherds exhibiting Caddoan designs and decorative elements. The possibility that the local people made pottery decorated in Caddoan styles provides an important clue to the dynamic nature of the Toyah social field in the middle Brazos River valley.

The Late Prehistoric component at 41BQ285 has certain characteristics that indicate it has the capacity to yield important archeological information. These include good contextual integrity and isolability of the Late Prehistoric component, as indicated by the radiocarbon dates, diagnostic artifacts, intact features, and vertical distributions of the cultural materials. Well-preserved organic materials, including faunal and charred botanical remains, could also provide data for interpreting subsistence activities.

Arguing against these positive characteristics, however, are several negative facts. The portion of the site comprising the FM 56 project area is a narrow 4- to 6-m-wide slice, and much of it was removed during the current testing excavations (see Figure 2.1). The portion of the right of way adjacent to the highway is an active borrow ditch, and maintenance has disturbed the upper deposits. In addition, the 
overall artifact density is variable throughout the tested area, and in many places it is sufficiently low that additional work would probably not contribute any substantive new information. It is doubtful that additional work in this small area would contribute data useful for defining the range of activities and spatial patterning, thus limiting the meaningful interpretations for the tested portion of 41BQ285. The material culture sample gained from additional archeological investigations inside the highway right of way would be limited, and the data would not be particularly useful for analyzing the sociocultural identity of the people who inhabited 41BQ285 during the Toyah interval.

The portion of 41BQ285 within the FM 56 roadway is considered eligible for listing in the National Register of Historic Places (NRHP) or for designation as a State Archeological
Landmark (SAL). However, because the area within the highway right of way is minimal and the current archeological excavations have already recovered most of the intact deposits, additional investigations within the right of way cannot reasonably be expected to contribute any more significant archeological information. Therefore, no further fieldwork is recommended, and construction should be allowed to proceed. The portions of the site that fall outside the current project area may have a high research potential and should be considered potentially eligible for listing in the NRHP and for designation as a SAL. Finally, it must be noted that the Late Prehistoric archeological remains located beyond the highway right of way make 41BQ285 an especially good candidate for testing Shafer's (2006) Prairie Caddo model and examining communities and social fields. 


\section{REFERENCES CITED}

Andrefsky, William, Jr.

2000 Lithics: Macroscopic Approaches to Analysis. Cambridge University Press, Cambridge.

Arnn, John W., III

2005 Chronology, Technology and Subsistence: Is That All There Is? Council of Texas Archeologists Newsletter 29(2):17-28. September 2005. Austin, Texas.

2007 Transformation and Persistence of Indigenous Cultural Identity During the Early Colonial and Late Prehistoric Periods in Texas. Ph.D. dissertation, Department of Anthropology, University of Kentucky.

2010 Peoples of Texas: Native American Identity and Interaction in Texas, A.D. 1300 to A.D. 1700. University of Texas Press, Austin (in press).

Binford, Lewis R.

1978 Dimensional Analysis of Behavior and Site Structure: Learning from an Eskimo Hunting Stand. American Antiquity 43(3):330-361.

1980 Willow Smoke and Dogs' Tails: HunterGatherer Settlement Systems and Archaeological Site Formation. In American Antiquity 45:4-20.

Black, Steve, Lain W. Ellis, Darrell G. Creel, and Glen T. Goode

1997 Hot Rock Cooking on the Greater Edwards Plateau: Four Burned Rock Midden Sites in West Central Texas (two volumes). Studies in Archeology 22. Texas Archeological Research Laboratory, University of Texas at Austin; Archeology Studies Program Report No. 2, Environmental Affairs Division, Texas Department of Transportation, Austin.
Brown, David O., Richard Watson, Duane Peter, and V. Rawn-Schatzinger

1987 The McDonald Site: 41HI105. In Archeology at Aquilla Lake, 1978-1982 Investigations, Volume II, compiled by David O. Brown, pp. 38-1 to 38.145. Research Report 81. Texas Archeological Survey, University of Texas at Austin.

Collins, Michael B.

1990 The Archaeological Sequence of Kincaid Rockshelter, Uvalde County, Texas. Transactions of the Twenty-Fifth Regional Archeological Symposium for Southeastern New Mexico and Western Texas, pp. 25-34.

1995 Forty Years of Archeology in Central Texas. Bulletin of the Texas Archeological Society 66:361-400.

Collins, Michael B. (editor)

1998 Wilson-Leonard: An 11,000-Year Archeological Record of Hunter-Gatherers in Central Texas, Volumes I-V. Studies in Archeology 31. Texas Archeological Research Laboratory, University of Texas at Austin. Archeology Studies Program Report 10, Environmental Affairs Division, Texas Department of Transportation, Austin.

Collins, Michael B., and Kenneth M. Brown

2000 The Gault Gisement: Some Preliminary Observations. Current Archeology in Texas 2(1):8-11

Collins, Michael B., Bruce Ellis, and Cathy Dodt-Ellis 1990 Excavations at the Camp Pearl Wheat Site (41KR243): An Early Archaic Campsite on Town Creek, Kerr County, Texas. Studies in Archeology 6. Texas Archeological Research Laboratory, University of Texas at Austin. 
Collins, Michael B., Thomas R. Hester, and Pamela J. Headrick

1992 Engraved Cobbles from the Gault Site, Central Texas. Current Research in the Pleistocene 9:3-4.

Diamond, David D., David H. Riskind, and Steve L. Orzell

1987 A Framework for Plant Community Classification and Conservation in Texas. The Texas Journal of Science 39(3):203-221.

Diggs, George M., Jr., Barney L. Lipscomb, and Robert J. O'Kennon

1999 Shiners and Mahler's Illustrated Flora of North Central Texas. Botanical Research Institute of Texas (BRIT), Fort Worth.

Goode, Glenn T.

1991 Late Prehistoric Burned Rock Middens in Central Texas. In The Burned Rock Middens of Texas: An Archeological Symposium, edited by Thomas R. Hester, pp. 71-92. Studies in Archeology 13. Texas Archeological Research Laboratory, University of Texas at Austin.

2002 The Anthon Site: A Prehistoric Encampment in Southern Uvalde County, Texas. Archeological Studies Program Report No. 38, Environmental Affairs Division, Texas Department of Transportation, Austin.

Goode, Glenn T., and Robert J. Mallouf

1991 The Evant Cores: Polyhedral Blade Cores from North-Central Texas. Current Research in the Pleistocene 8:67-70.

Griffith, Timothy B.

2005 Archeological Survey on FM 56 at the North Bosque River, Bosque County, Texas. Letter Report No. 718. Prewitt and Associates, Inc., Austin, Texas.

Hatfield, Virginia L.

1997 Paleoindian Evidence at the Triple S Ranch Site, Hamilton County, Texas. Current Research in the Pleistocene 14:32-34.

Hayward, O. T., Peter M. Allen, and David L. Amsbury 1996 Lampasas CutPlain:Episodic Development of an Ancient and Complex Regional Landscape, Central Texas. In Guidebook to Upland, Lowland, and In Between: Landscapes in the Lampasas Cut Plain, edited by David L. Carlson, pp. 1-1 to 1-97. Friends of Pleistocene South-Central Cell 1996 Field Trip. Department of
Anthropology, Texas A\&M University, College Station, and Department of Geology, Baylor University, Waco.

Henry, Donald O., Foster E. Kirby, and Anne B. Justen 1980 The Prehistory of Hog Creek: An Archaeological Investigation of Bosque and Coryell Counties, Texas. Laboratory of Archaeology, Department of Anthropology, University of Tulsa, Oklahoma.

Hester, Thomas R., Stephen L. Black, D. Gentry Steele, Ben W. Olive, Anne A. Fox, Karl J. Reinhard, and Leland C. Bement

1989 From the Gulf to the Rio Grande: Human Adaptation in Central, South, and Lower Pecos Texas. Arkansas Archeological Survey Research Series No. 33. Arkansas Archeological Survey, Fayetteville.

Hill, Robert T.

1901 Geography and Geology of the Black and Grand Prairies, Texas, with Detailed Descriptions of the Cretaceous Formations and Special Reference to Artesian Waters. In Twenty-First Annual Report to the United States Geological Survey 1899-1900, Part 7: Texas. U.S. Geological Survey, Denver.

Howells, Robert G., Raymond W. Neck, and Harold D. Murray

1996 Freshwater Mussels of Texas. Texas Parks and Wildlife Department, Austin.

Huebner, Jeffery A.

1991 Late Prehistoric Bison Populations in Central and South Texas. Plains Anthropologist 36(137):343-358.

Jelks, Edward B.

1962 The Kyle Site: A Stratified Central Texas Aspect Site in Hill County, Texas. Archeology Series No. 5. Department of Anthropology, University of Texas at Austin.

Johnson, LeRoy, Jr.

1994 The Life and Times of Toyah-Culture Folk, The Buckhollow Encampment Site 41KM16, Kimble County, Texas. Office of the State Archeologist Report 38, Texas Department of Transportation and Texas Historical Commission, Austin.

2000 Life and Death as Seen at the Bessie Kruze Site (41WM13) on the Blackland Prairie of Williamson County, Texas. Archeology Studies Program, Report 22. Environmental Affairs Division, Archeology Studies 
Program, Texas Department of Transportation, Austin.

Johnson, LeRoy, and Glenn T. Goode

1994 A New Try at Dating and Characterizing Holocene Climates, as well as Archeological Periods, on the Eastern Edwards Plateau. Bulletin of the Texas Archeological Society 65:1-51.

Karbula, James

2003 The Toyah Bluff Site (41TV441)—Changing Notions of the Late Prehistoric Subsistence in the Blackland Prairie Along the Eastern Edge of the Edwards Plateau, Travis County, Texas. In Bulletin of the Texas Archeological Society 74:55-81.

Kelley, J. Charles, Thomas N. Campbell, and Donald J. Lehmer

1940 The Association of Archaeological Materials with Geological Deposits in the Big Bend Region of Texas. Sul Ross State Teachers College Bulletin 21(3).

Kelly, Robert L.

1995 The Foraging Spectrum. Smithsonian Institution Press, Washington D.C.

Kenmotsu, Nancy

2001 Making Friends, Avoiding Enemies: The Jumano Response to Spanish Colonization, A.D. 1580-1750. Bulletin of the Texas Archeological Society 72:23-44.

Kenmotsu, Nancy, and Douglas K. Boyd

n.d. The Toyah Phase in Texas: An Introduction and Retrospective. In Small Scale Societies: Revisiting the Toyah Phase in the Southern Plains of Central Texas to Study Economic and Social Processes, edited by Nancy A. Kenmotsu and Douglas K. Boyd. Texas A\&M University Press, College Station, Texas. In press.

Kenmotsu, Nancy A., and Mariah F. Wade

2002 Amistad National Recreation Area, Del Rio, Texas. American Indian Tribal Affiliation Study. Phase I: Ethnohistoric Literature Review. Archeological Studies Program Report No. 34, Environmental Affairs Division, Texas Department of Transportation, Austin, in cooperation with the National Park Service.

Kibler, Karl W., and Cory J. Broehm

2005 Data Recovery at Site 41HM51, Hamilton County, Texas. Current Archeology in Texas 7(1):18-22.
Kleinbach, Karl, Gemma Mehalchick, James T. Abbott, and J. Michael Quigg

1995 Burned Rock Mounds, Middens, Concentrations, and Pavements. In NRHP Significance Testing of 57 Prehistoric Archeological Sites on Fort Hood, Texas, Volume II, edited by James T. Abbott and W. Nicholas Trierweiler, pp. 765-801. Research Report No. 34. Archeological Resource Management Series, United States Army, Fort Hood.

Lesser, Alexander

1961 Social Fields and the Evolution of Society. Southwestern Journal of Anthropology 17:40-48. University of New Mexico, Albuquerque.

Mauldin, Raymond P., and David L. Nickels, and Cory J. Broehm

2003 Archaeological Testing to Determine the National Register Eligibility Status of 18 Prehistoric Sites on Camp Bowie, Brown County, Texas. Vol. 1. Adjutant General's Department of Directorate of Facilities and Engineering. Archaeological Survey Report No. 334. Center for Archaeological Research, University of Texas at San Antonio.

McKinney, Wilson W.

1981 Early Holocene Adaptations in Central and Southwestern Texas: The Problem of the Paleoindian-Archaic Transition. Bulletin of the Texas Archeological Society 52:91-120.

Mehalchick, Gemma, and Karl W. Kibler

2008 Hunters and Gatherers of the North Bosque River Valley: Excavations at the Baylor, Britton, McMillan, and Higginbotham Sites, Waco Lake, McLennan County, Texas. Reports of Investigations, No. 156. Prewitt and Associates, Inc., Austin.

Mehalchick, Gemma, Kyle Killian, S. Christopher Caran, and Karl W. Kibler

2003 Geoarcheological Investigations and $\mathrm{Na}$ tional Register Testing of 57 Prehistoric Archeological Sites on Fort Hood: The 1999 Season. Research Report No. 44. Archeological Resource Management Series, United States Army, Fort Hood.

Mehalchick, Gemma, Karl Kleinbach, Douglas K. Boyd, and Karl W. Kibler

2000 Geoarcheological Investigations and $\mathrm{Na}$ tional Register Testing of 52 Prehistoric Archeological Sites on Fort Hood, Texas: 
The 1997 Season. Archeological Resource Management Series, Research Report No. 39. United States Army, Fort Hood.

Mehalchick, Gemma, Karl Kleinbach, Douglas K. Boyd, Steve A. Tomka, and Karl W. Kibler

1999 National Register Testing of 19 Prehistoric Archeological Sites at Fort Hood, Texas: The 1995 Season. Archeological Resource Management Series, Research Report No. 37. United States Army, Fort Hood.

Mehalchick, Gemma, Terri Myers, Karl W. Kibler, and Douglas K. Boyd

1999 Val Verde on the Sunny Rio Grande: Geoarcheological and Historical Investigations at San Felipe Springs, Val Verde County, Texas. Reports of Investigations No. 122. Prewitt and Associates, Inc., Austin.

Nagaoka, Lisa

2005 Declining Foraging Efficiency and Moa Carcass Exploitation in Southern New Zealand. Journal of Anthropological Science 32:1328-1338.

Natural Fibers Information Center

1987 The Climates of Texas Counties. Natural Fibers Information Center, University of Texas at Austin, in cooperation with the Office of the State Climatologist, Texas A\&M University.

Nordt, Lee C.

1995 Geoarchaeological Investigations of Henson Creek: A Low-Order Tributary in Central Texas. Geoarchaeology 10(3):205-221.

Omernik, James M.

2003 Level III Ecoregions of Texas. Map adapted from "Level III Ecoregions of the Continental United States (revision of Omernik, 1987) by the U.S. Environmental Protection Agency. Corvallis, Oregon, Electronic document available from the Texas Parks and Wildlife Department, http://www. tpwd.state.tx.us/landwater/land/maps/gis/ map_downloads.

Perttula, Timothy, and Myles Miller, Robert Ricklis, Daniel Prikryl, and Christopher Lintz

1995 Prehistoric and Historic Aboriginal Ceramics in Texas. In Bulletin of the Texas Archeological Society 66:175-235.

Perttula, Timothy K., Sergio A. Iruegas, and Hector Neff

2003 Caddoan Pottery in Central Texas: Geochemical Analysis of Ceramics from Fort
Hood and Vicinity. Archeological Resource Management Series, Research Report No. 51. United States Army, Fort Hood.

Prewitt, Elton R.

1981 Cultural Chronology in Central Texas. Bulletin of the Texas Archeological Society 52:65-89.

1985 From Circleville to Toyah: Comments on Central Texas Chronology. Bulletin of the Texas Archeological Society 54:201-238.

Quigg, J. Michael

1997 Bison Processing at the Rush Site, 41TG346, and Evidence for Pemmican Production in the Southern Plains. In Southern Plains Bison Procurement and Utilization from Paleoindian to Historic, edited by L. C. Bennett and K. J. Buehler, pp. 145-162. Plains Anthropologist, Memoir 29.

Quigg, J. Michael and Jay Peck

1995 The Rush Site (41TG346) A Stratified Late Prehistoric Locale in Tom Green County, Texas. Technical Report No. 816C. Mariah Associates, Inc., Austin.

Redder, Albert J.

1985 Horn Shelter Number 2: The South End, A Preliminary Report. Central Texas Archeologist 10:37-65.

Ricklis, Robert A.

1992 The Spread of a Late Prehistoric Bison Hunting Complex: Evidence from the South-Central Coastal Prairie of Texas. In Plains Anthropologist 37 (140):621-674.

1994 Toyah Components: Evidence for Occupations in the Project Area During the Latter Part of the Late Prehistoric Period. In Archaic and Late Prehistoric Human Ecology in the Middle Onion Creek Valley, Hays County, Texas, by R. A. Ricklis and M. B. Collins, Vol. 1, pp. 207-316. Studies in Archeology 19, Texas Archeological Research Laboratory, University of Texas at Austin.

1995 Prehistoric Occupation of the Central Texas Coast: A Regional Overview. In Bulletin of the Texas Archeological Society 66:265-300.

Scott, Ann M., Karl W. Kibler, and Marie E. Blake 2002 National Register Testing of Nine Archeological Sites at Waco Lake, McLennan 
County, Texas. Reports of Investigations No. 132. Prewitt and Associates, Inc., Austin, Texas.

Shafer, Harry J.

1963 Test Excavations at the Youngsport Site: A Stratified Terrace Site in Bell County, Texas. Bulletin of the Texas Archeological Society 34:57-81.

1973 Lithic Technology at the George C. Davis Site, Cherokee County, Texas. Ph.D. dissertation, Department of Anthropology, University of Texas at Austin.

2006 People of the Prairie: A Possible Connection to the Davis Site Caddo. Report prepared for the Archeological Studies Program, Environmental Affairs Division, Texas Department of Transportation, Austin. Electronic document, http:// www.counciloftexasarcheologists.org/ publications/PrairieCaddoModule.pdf, accessed March 7, 2007.

Shafer, H. J., D. A. Suhm, and J. D. Scurlock

1964 An Investigation and Appraisal of the Archeological Resources of Belton Reservoir, Bell and Coryell Counties, Texas: 1962. Miscellaneous Papers No. 1. Texas Archeological Salvage Project, University of Texas at Austin.

Sorrow, William M., Harry J. Shafer, and Richard E. Ross

1967 Excavations at Stillhouse Hollow Reservoir. Miscellaneous Papers No. 11. Texas Archeological Salvage Project, University of Texas at Austin.

Stephenson, Robert L.

1970 Archeological Investigations in the Whitney Reservoir Area, Central Texas. Bulletin of the Texas Archeological Society 41:37-277.

Story, Dee Ann

1972 A Preliminary Report of the 1968, 1969, and 1970 Excavations at the George C. Davis Site, Cherokee County, Texas. University of Texas at Austin.

1985 Adaptive Strategies of Archaic Cultures of the West Gulf Coastal Plain. In Prehistoric Food Production in North America, edited by Richard I. Ford, pp. 19-56. Anthropological Papers No. 75. Museum of Anthropology, University of Michigan, Ann Arbor.
1990 Cultural History of the Native Americans. In The Archeology and Bioarcheology of the Gulf Coastal Plain, by Dee Ann Story, Janice A. Guy, Barbara A. Burnett, Martha Doty Freeman, Jerome C. Rose, D. Gentry Steele, Ben W. Olive, and Karl J. Reinhard, pp. 163-366. Research Series No. 38. Arkansas Archeological Survey, Fayetteville.

Story, Dee Ann, and Harry J. Shafer

19651964 Excavations at Waco Reservoir, McLennan County, Texas: The Baylor and Britton Sites. Miscellaneous Papers No. 6. Texas Archeological Salvage Project, University of Texas at Austin.

Stringer, Billy R.

1980 Soil Survey of Bosque County, Texas. United States Department of Agriculture, Soil Conservation Service, in cooperation with Texas Agricultural Experiment Station.

Toomey, Rickard S., III, Michael D. Blum, and Salvatore Valastro, Jr.

1993 Late Quaternary Climates and Environments of the Edwards Plateau, Texas. Global and Planetary Change 7:299-320.

Treece, Abby C., Christopher Lintz, W. Nicholas Trierweiler, J. Michael Quigg, and Kevin Miller

1993 Cultural Resource Investigations in the O. H. Ivie Reservoir, Concho, Coleman, and Runnels Counties, Texas. Volume IV: Data Recovery from Ceramic Sites. Technical Report No. 346-IV. Mariah Associates, Inc., Austin.

Trierweiler, W. Nicholas (editor)

1994 Archeological Investigations on 571 Prehistoric Sites at Fort Hood, Bell and Coryell Counties, Texas. Archeological Resource Management Series, Research Report No. 31. United States Army, Fort Hood.

Turner, Robert L., Jr.

1997 Analysis of the Asa Warner (41ML46) Ceramics. In Bulletin of the Texas Archeological Society 68:231-239.

Wade, Mariah

2001 Cultural Fingerprints: The Native Americans of Texas 1528-1687. In Bulletin of the Texas Archeological Society 72:45-54.

2003 Native Americans of the Texas Edwards Plateau, 1582-1799. University of Texas Press, Austin. 
Watt, Frank H.

1941 Preliminary Report on Potsherds from the Chupik Site. Central Texas Archeological Society Newsletter 2(4)17-19.

1953 Pottery Diffusions of the Central Brazos Valley. Central Texas Archeologist 6:57-85.

1956 Archeological Materials from the Asa Warner Sites. Central Texas Archeologist 7:6-29.

1978 Radiocarbon Chronology of Sites in the Central Brazos Valley. Bulletin of the Texas Archeological Society 49:111-138.

Weir, Frank A.

1976 The Central Texas Archaic. Ph.D. dissertation, Department of Anthropology, Washington State University, Pullman.

Welsch, Robert L., and John E. Terrell

1998 Material Culture, Social Fields, and Social Boundaries on the Sepik Coast of New Guinea. In The Archaeology of Social Boundaries, edited by Miriam T. Stark. Smithsonian Institution Press. Washington.
Willey, Gordon R., and Philip Phillips

1958 Method and Theory in American Archaeology. University of Chicago Press, Chicago.

Wobst, H. Martin

1974 Boundary Conditions for Paleolithic Social Systems: A Simulation Approach. In American Antiquity 39:147-178.

Wright, J. F.

1997 The Asa Warner Site (41ML46), McLennan County, Texas. Bulletin of the Texas Archeological Society 68:215-261.

Yellen, John E.

1977 Anthropological Approaches to the Present: Models for Reconstructing the Past. Academic Press, New York. 


\title{
APPENDIX A: Analysis of Vertebrate Remains
}

\author{
Brian S. Shaffer \\ Dallas Historical Society
}





\section{INTRODUCTION}

Vertebrate remains recovered from 41BQ285 were analyzed to assess the types of taxa represented, any cultural modifications, and noncultural taphonomic impacts in the recovered assemblage. Environmental factors were also considered, including habitat use and exploitation of the available vertebrates, especially those taxa of greatest economic abundance. The sample analyzed consists of 1,673 specimens recovered from the excavation.

\section{METHODS}

Specimens were analyzed using the comparative collection at the Zooarchaeology Laboratory of the University of North Texas's Institute of Applied Sciences. Identifications were made based on visual comparison with these specimens. Identifications that were equivocal were either taken to the next higher level (e.g., from genus to family level) or were given "cf." as a prefix to indicate that the specimen compared favorably with the taxon but the identification was equivocal.

Attributes were recorded using a vertebrate faunal analysis coding system (Shaffer and Baker 1992). Attributes recorded included taxon, element, portion of element, siding, age criteria, aging, weathering, breakage, dynamic impact damage, burning, gnawing, chemical dissolution (both of uncertain origin and root etching), and presence of bone grease; additional information such as notation of medical disorders and cut marks was recorded in a comments field.

The remains were tabulated using two methods. The number of identified specimens (NISP), or simple specimen count, was tabulated for each category of identification. The minimum number of individuals (MNI) was computed as a single aggregate based on element, portion of element, and aging criteria for each unique taxonomic group, usually at the genus level. Aging was also taken into account based on age categories (e.g., juvenile, subadult, and adult). The MNI calculations were not increased with the addition of age categories - except in the case of deer, where one subadult expanded the MNI tabulation from two to three individuals. Broader categories such as Aves (birds) and Mammalia (mammals) were not tabulated by MNI.
In some cases, broad categories need to be examined along with subcategories to ascertain if more individuals are actually present than are identified in the more specific categories. For example, turtles were identified as Testudinata (unidentified turtle), Emydidae (water and box turtles), and Terrapene sp. (box turtles). It is possible that only box turtles are present in the assemblage, since box turtle is the only genus identified. In the family Emydidae and order Testudinata, however, there are several species of turtles that overlap in size with box turtles, so it might be possible to identify more individuals if there is a duplication of elements between the more specific box turtle identification and the less specific family and order identifications. In this case, though, comparison of the turtle elements recovered did not reveal any duplication of unique elements, and as such, even when combining all of the turtle remains as a single group, it is possible that all the remains came from just one individual box turtle.

Medium-sized Artiodactyl (deer/pronghornsized ungulates), Cervidae (deer and relatives), and Odocoileus sp. (deer) elements represent three-quarters of the identified assemblage $(n=126)$, which is the portion of the assemblage identified to at least the level of order or below $(\mathrm{n}=169)$. Since pronghorn antelope are comparable in size to deer, and their highly fragmented remains are not readily distinguished from deer, it was deemed necessary to calculate MNI based on all medium-sized artiodactyl remains to determine if more individuals might be identified than by looking at deer alone. As with the turtles, using all of the medium-sized artiodactyl remains for MNI did not produce any additional individuals over the results of deer alone.

Taphonomic information was recorded for each specimen, including both natural and cultural processes. Weathering was recorded as "light" or "marked" depending on the amount of damage to the bone's exterior resulting from exposure. Specimens with little or no significant surface damage were recorded as having light weathering. Those with fine-line cracking and exfoliation were the specimens in the worst condition and were recorded as having marked weathering.

A second surface impact that is sometimes associated with weathering is chemical etching and dissolution. Osseous and dental elements 
can be impacted by ground $\mathrm{pH}$, roots, and ingestion by animals such as carnivores and raptors. Light amounts of etching were noted when the etching did not impact much of the surface of the specimen, but was prominent enough to be readily spotted during analysis. Marked chemical etching was recorded when a significant portion of the specimen's surface was deteriorated or when it precluded identification through the destruction of landmarks. The only positive form of chemical dissolution observed was root etching, and the patterns of rootlets were observed on several specimens.

Breakage was recorded as unbroken, angularly fractured, or spirally fractured. Angular fractures are produced in bones that usually do not spirally fracture (e.g., flat bones such as some cranial, rib, and pelvic elements, teeth, turtle shell) or when bone has lost its collagen (Johnson 1985). Spiral fractures are most common in long bones but can occur in other thickwalled cortical bone. Although spiral fractures can be produced by carnivores, they are often the result of intentional breakage of the bone for the removal of the marrow or for processing into grease (e.g., Johnson 1985; Lintz 1976:87-88). This intentional breakage often is produced by percussion, resulting in impact marks on the bone (Johnson 1985).

Burning was noted as charred, burned brown or black; or calcined, burned white. Charring results in incomplete combustion of the bone, whereas calcination is a more complete burning of the bone. Bones observed as being heavily scorched, but not actually black, were also recorded as charred.

Specimens were also observed for gnawing, cut marks, and evidence of medical disorders. Only one form of gnawing was noted. Only one specimen was identified with cut marks. No specimens showed signs of medical disorders.

\section{TAXONOMIC OBSERVATIONS}

Animal taxa exploited came from both terrestrial and aquatic habitats, although terrestrial taxa were more important economically. Some of the turtle remains could be from aquatic turtles, but no aquatic turtles were identified. The assemblage is dominated by artiodactyls, distantly followed by turtles, then various other taxa, usually smaller animals (Table A.1). These smaller taxa are represented by only a few specimens, each with an MNI of one. While the remains of larger taxa may be easier to recover and identify, the overall lack of smaller fauna compared to artiodactyls and medium/large mammal remains indicates that larger fauna contributed significantly to the animal portion of the diet.

Whereas deer-sized artiodactyl remains dominate the identified assemblage, medium/ large mammal (canid/deer-sized mammals) remains dominate the unidentified assemblage. Undoubtedly, these remains are comprised mainly of deer-sized artiodactyl bones, but they are too fragmented for more specific identification.

The analysis revealed two unusual findings: armadillo remains and a specimen of large/ very large mammal. The armadillo remainsrecovered from Test Unit 5, Level 2, 10-20 cm below surface-are dermal ossicles (shell). These bony plates are unique structures that are not easily confused with bony elements from any other North American taxa. Armadillos were not present in Texas prehistorically; their migration northward from Mexico occurred in the last 100 years or so (see Schmidly 1983:103). Therefore, these remains are not part of the prehistoric assemblage at the site. The large/ very large mammal specimen-recovered from Test Unit 2, Level 4, 30-40 cm below surface-is a long bone shaft fragment that is most likely from a large artiodactyl such as bison or elk. With no diagnostic attributes beyond size, however, it could only be identified as large/ very large mammal.

\section{TAPHONOMIC OBSERVATIONS}

Table A. 2 shows the taphonomic impacts on the assemblage by provenience. The most significant taphonomic impacts are breakage and burning. Spiral breakage is associated with the breaking of cortical bone while it is still fresh or contains collagen (bone grease). When bone has lost its grease, the fracture pattern tends to be more angular. While spiral fractures may be associated with human activity (e.g., Binford 1978:158; DeMarcay 1986; Lintz 1976:87-88; Vehik 1977:172; Zierhut 1967:33-36), they can occur due to various nonhuman processes such as trauma to a living animal, gnawing by a carnivore, and even trampling of bone in some cases. No signs of carnivore damage or trampling were noted. 
Table A.1. Number of identified specimens (NISP) and minimum number of individuals (MNI) by faunal taxon and common name

\begin{tabular}{l|l|c|c}
\hline \multicolumn{1}{c|}{ Taxon } & \multicolumn{1}{c|}{ Common Name } & NISP & MNI \\
\hline Vertebrata & Vertebrates & 674 & \\
\hline Lepisosteidae & Gars & 1 & 1 \\
\hline Testudinata & Turtles & 17 & \\
\hline Emydidae & Water and box turtles & 1 & 1 \\
\hline Terrapene sp. & Box turtles & 1 & \\
\hline Lacertilia & Lizards & 2 & \\
\hline Serpentes & Snakes & 5 & 1 \\
\hline Colubridae & Colubrid snakes & 1 & 1 \\
\hline Viperidae & Pitviper snakes & 1 & \\
\hline cf. Viperidae & Pitviper snakes & 5 & \\
\hline Aves (Large) & Large birds & 1 & 1 \\
\hline Meleagris gallapavo & Turkey & 1 & \\
\hline Mammalia (Micro/small) & Shrew/rabbit-sized mammals & 1 & \\
\hline Mammalia (Small) & Rabbit-sized mammals & 8 & \\
\hline Mammalia (Small/medium) & Rabbit/canid-sized mammals & 814 & \\
\hline Mammalia (Medium/large) & Canid/deer-sized mammals & 1 & \\
\hline Mammalia (Large/very large) & Deer/bison-sized mammals & 4 & 1 \\
\hline Dasypus novemcinctus & Nine-banded armadillo & 2 & 1 \\
\hline Sylvilagus sp. & Cottontail rabbits & 1 & 1 \\
\hline Rodentia (Medium) & Medium rodent & 5 & 1 \\
\hline Procyon lotor & Raccoon & 74 & \\
\hline Artiodactyla (Medium) & Deer/pronghorn-sized ungulates & 2 & \\
\hline Cervidae & Deer and relatives & 50 & 3 \\
\hline Odocoileus sp. & Deer & 1,673 & \\
\hline Total NISP & & & \\
\hline & & & \\
\hline
\end{tabular}

While angular breakage dominates the assemblage $(n=1,237)$, spiral fracturing $(n=408)$ that potentially could be associated with human activity is well represented, especially when accompanied by impact fractures, which would indicate the intentional human breakage of the bone (Johnson 1985:192). Spiral fractures were identified in 24 percent of the assemblage. While the studies above noted more extensive processing of bone (smaller pieces) for grease rendering, it should be pointed out that experiments indicate that bone fragment size is not a good indicator for this activity, since grease can be rendered from large or small fragments (Church and Lyman 2003).

Burning, however, is more equivocal because there are no definitive burn patterns to indicate specifically that bones were burned by humans, either intentionally or unintentionally, unless they are found in hearths. Had bones been burned as a result of a natural fire, however, then a pattern might have been observed in the field of a lens of burned bone, and no such lens was reported. Thus, most or all of the burned bone is likely the product of human activity. A total of 398 (24 percent) specimens were identified as burned, of which 249 were charred and 149 were calcined.

Weathering produced minimal impact on the assemblage, with only four specimens recorded as having marked weathering. These bones exhibit longitudinal fracturing. The lack of specimens with marked weathering indicates that the assemblage was buried relatively quickly, before exposure could produce any significant amount of damage. 
Table A.2. Faunal taphonomy by provenience

\begin{tabular}{|c|c|c|c|c|c|c|}
\hline & Nonfeature & Feature 1 & $\begin{array}{c}\text { Feature } 2 \\
\text { (East } \\
\text { Half) } \\
\end{array}$ & $\begin{array}{c}\begin{array}{c}\text { Feature } 2 \\
\text { (West } \\
\text { Half) }\end{array} \\
\end{array}$ & Feature 3 & Total \\
\hline Light Weathering & 1,287 & 42 & 162 & 173 & 5 & 1,669 \\
\hline Marked Weathering & 4 & & & & & 4 \\
\hline Unbroken & 26 & & 2 & & & 28 \\
\hline Angular Break & 915 & 40 & 141 & 137 & 4 & 1,237 \\
\hline Spiral Break & 350 & 2 & 19 & 36 & 1 & 408 \\
\hline Impact Fracture & 7 & & & & & 7 \\
\hline Unburned & 976 & 40 & 100 & 156 & 3 & 1,275 \\
\hline Charred & 186 & 2 & 44 & 15 & 2 & 249 \\
\hline Calcined & 129 & & 18 & 2 & & 149 \\
\hline $\begin{array}{l}\text { Light Chemical } \\
\text { Etching }\end{array}$ & 15 & & & & & 15 \\
\hline $\begin{array}{l}\text { Marked Chemical } \\
\text { Etching }\end{array}$ & 6 & & & & & 6 \\
\hline Light Root Impact & 16 & & & 1 & & 17 \\
\hline Marked Root Impact & 1 & & & & & 1 \\
\hline Rodent Gnawing & 1 & & & & & 1 \\
\hline Cut Marks & & & & 1 & & 1 \\
\hline
\end{tabular}

After burial, however, some specimens did suffer root damage $(n=18)$, and this may be when specimens suffered unidentified chemical damage $(n=21)$. In both cases, the surface of the bone is impacted by a chemical reaction, resulting in dissolution of the surface of the bone. With root damage, the patterns of the roots can be seen across the surface of the bone. When this is very extensive, the patterning can result in a generalized total surface disfigurement and no longer be recognized as root etching. Similarly, reactions by caustic soil $\mathrm{pH}$ or carnivore digestion can result in dissolution of the surface of the bone. Given the overall low frequencies of root and chemical etching, these do not appear to be significant factors affecting assemblage preservation. Neither does rodent gnawing, of which just one specimen was identified.

\section{PATTERNING OF NONFEATURE AND FEATURE AREAS}

In examining the distribution of taxa between nonfeature and feature areas to ascertain the possibility of taxa-related activities (Table A.3), no unique taxa or concentrations of taxa were identified in the feature areas that were not in the nonfeature areas, with the exception of the rodent bone. Additionally, there does not appear to be any particular representational density by taxon or taxonomic group in the feature areas. Given that 1,291 (77 percent) of the assemblage was recovered from nonfeature contexts, this patterning is not unexpected.

In looking at the taphonomic breakdown by nonfeature and feature areas (see Table A.2), a similar pattern is evident, with the nonfeature areas usually dominating in both frequencies and area percentages of possible and probable cultural impacts such as spiral breakage, impact fracturing, and burning. The only exception is the lone cut avian bone from Feature 2-west half. As such, it would appear that most animal processing or deposition took place away from feature areas. If processing did occur in feature areas, bones were probably discarded away from those areas.

\section{SUMMARY}

The faunal assemblage from 41BQ285 contains 1,673 specimens assigned to a Late Archaic component $(\mathrm{n}=53)$, a Toyah phase component $(\mathrm{n}=1,524)$, and unassigned $(\mathrm{n}=96)$ as presented in Table A.4. 
Table A.3. Number of identified specimens by provenience

\begin{tabular}{|c|c|c|c|c|c|}
\hline Taxon & Nonfeature & Feature 1 & $\begin{array}{c}\text { Feature } 2 \\
\text { (East Half) }\end{array}$ & $\begin{array}{c}\text { Feature } 2 \\
\text { (West Half) }\end{array}$ & Feature 3 \\
\hline Vertebrata & 370 & 36 & 124 & 139 & 5 \\
\hline Lepisosteidae & 1 & & & & \\
\hline Testudinata & 15 & & 2 & & \\
\hline Emydidae & 1 & & & & \\
\hline Terrapene sp. & 1 & & & & \\
\hline Lacertilia & 1 & & & & \\
\hline Serpentes & 2 & & & & \\
\hline Colubridae & 3 & & & 2 & \\
\hline Viperidae & 1 & & & & \\
\hline cf. Viperidae & & & 1 & & \\
\hline Aves (Large) & 4 & & & 1 & \\
\hline Meleagris gallapavo & 1 & & & & \\
\hline Mammalia (Micro/small) & 1 & & & & \\
\hline Mammalia (Small) & 1 & & & & \\
\hline Mammalia (Small/medium) & 6 & & 2 & & \\
\hline Mammalia (Medium/large) & 753 & 2 & 32 & 27 & \\
\hline Mammalia (Large/very large) & 1 & & & & \\
\hline Dasypus novemcinctus & 4 & & & & \\
\hline Sylvilagus sp. & 1 & & & 1 & \\
\hline Rodentia (Medium) & & & & 1 & \\
\hline Procyon lotor & 5 & & & & \\
\hline Artiodactyla (Medium) & 69 & 3 & & 2 & \\
\hline Cervidae & 2 & & & & \\
\hline Odocoileus sp. & 48 & 1 & 1 & & \\
\hline Total NISP & 1,291 & 42 & 162 & 173 & 5 \\
\hline
\end{tabular}

Analysis of the vertebrate remains revealed a highly fragmented assemblage dominated by medium-sized artiodactyl, deer, and canid/deersized remains (probably from deer). Smaller taxa are represented in much smaller numbers. With the exception of a single gar scale, all of the identified remains are of terrestrial fauna. The one unexpected find for a prehistoric assemblage is armadillo shell remains, which would have been introduced into the site in the last 100 years.
Taphonomically, the assemblage is highly comminuted, primarily by forces acting on the assemblage after collagen loss from the bones. A significant portion of the assemblage, however, appears to have been processed for marrow or grease, as indicated by spiral fracturing and impact points on several bones. Burning was also a significant factor. With only one avian specimen identified with cut marks, no butchery patterns could be discerned. 


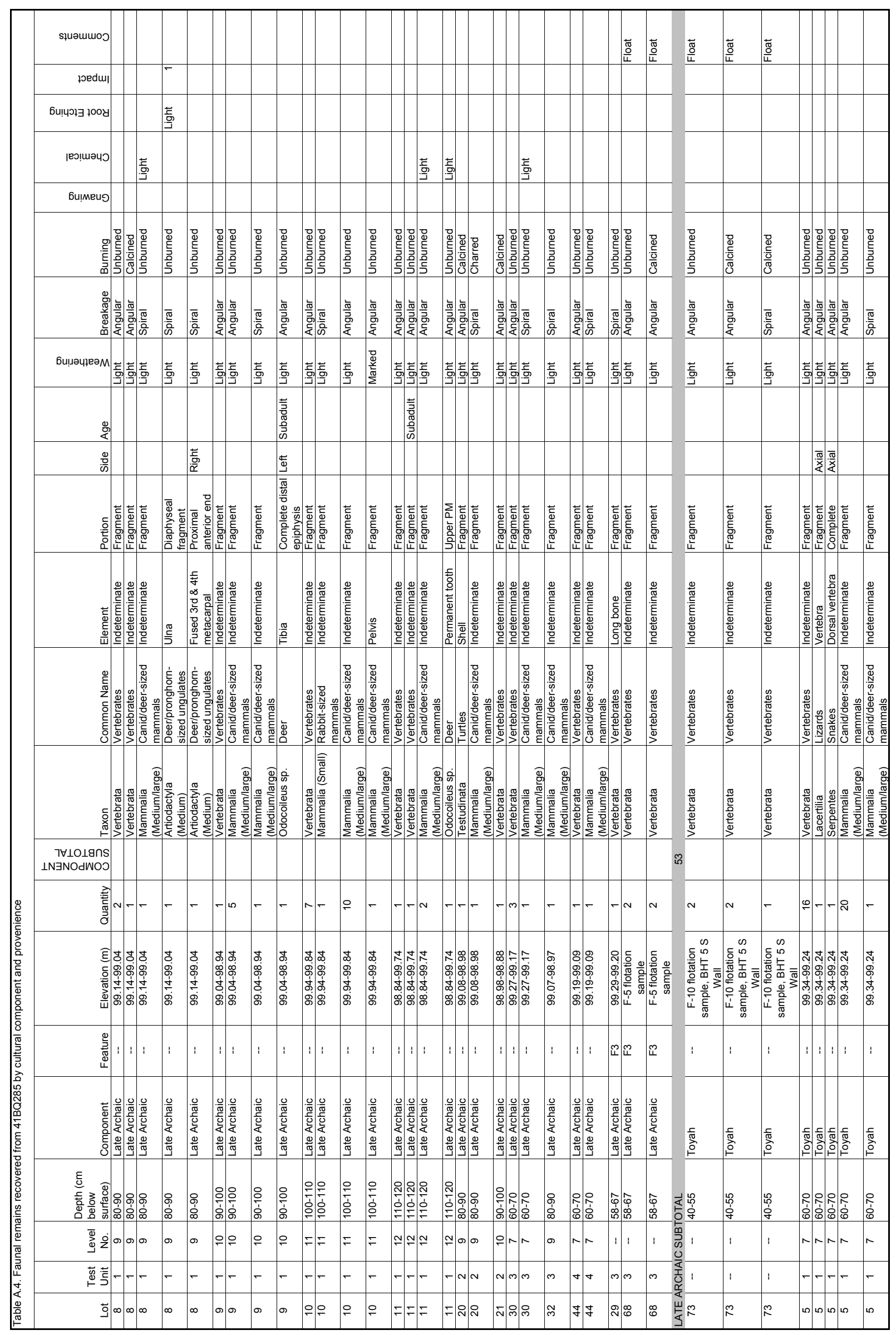




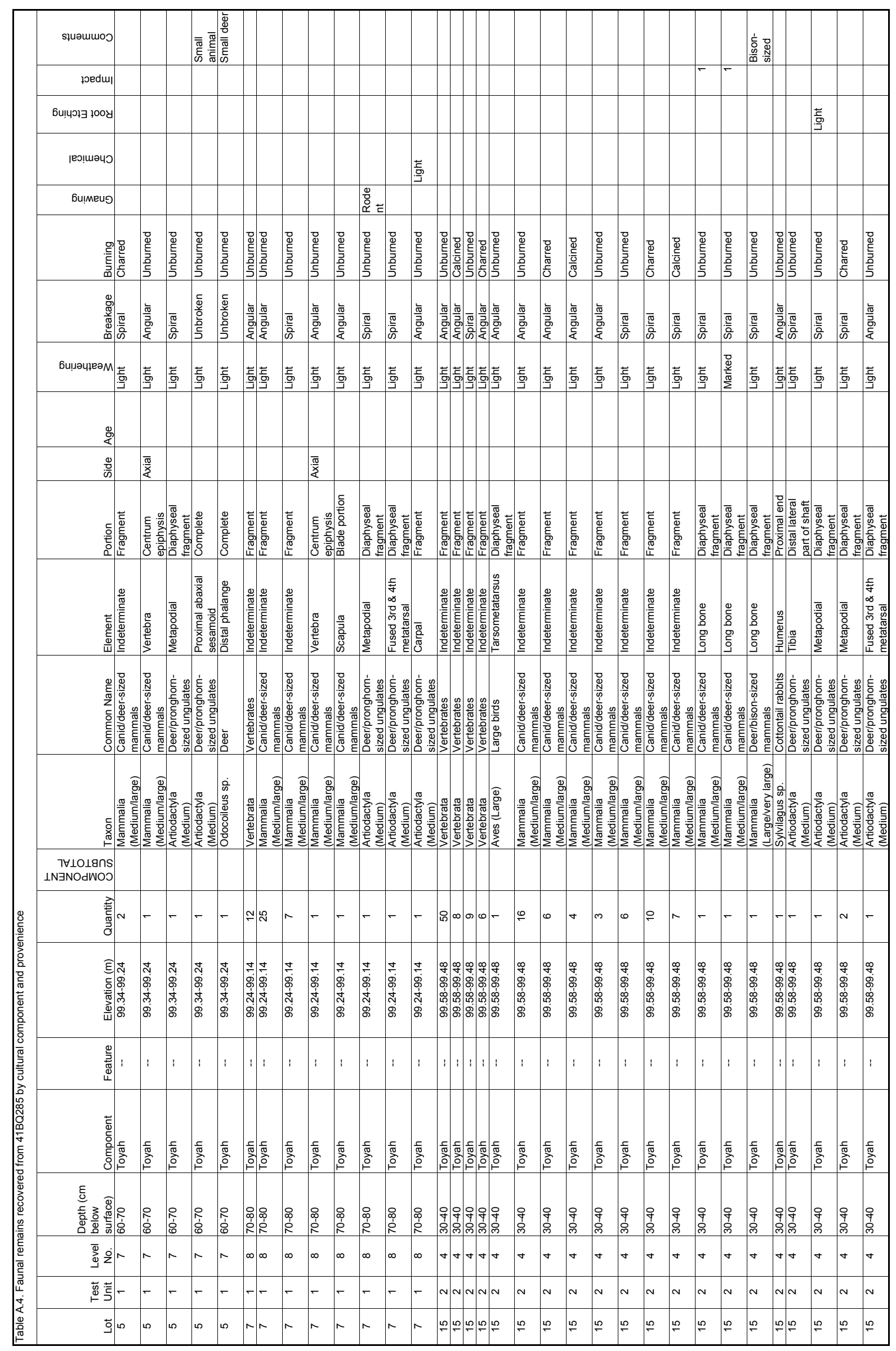




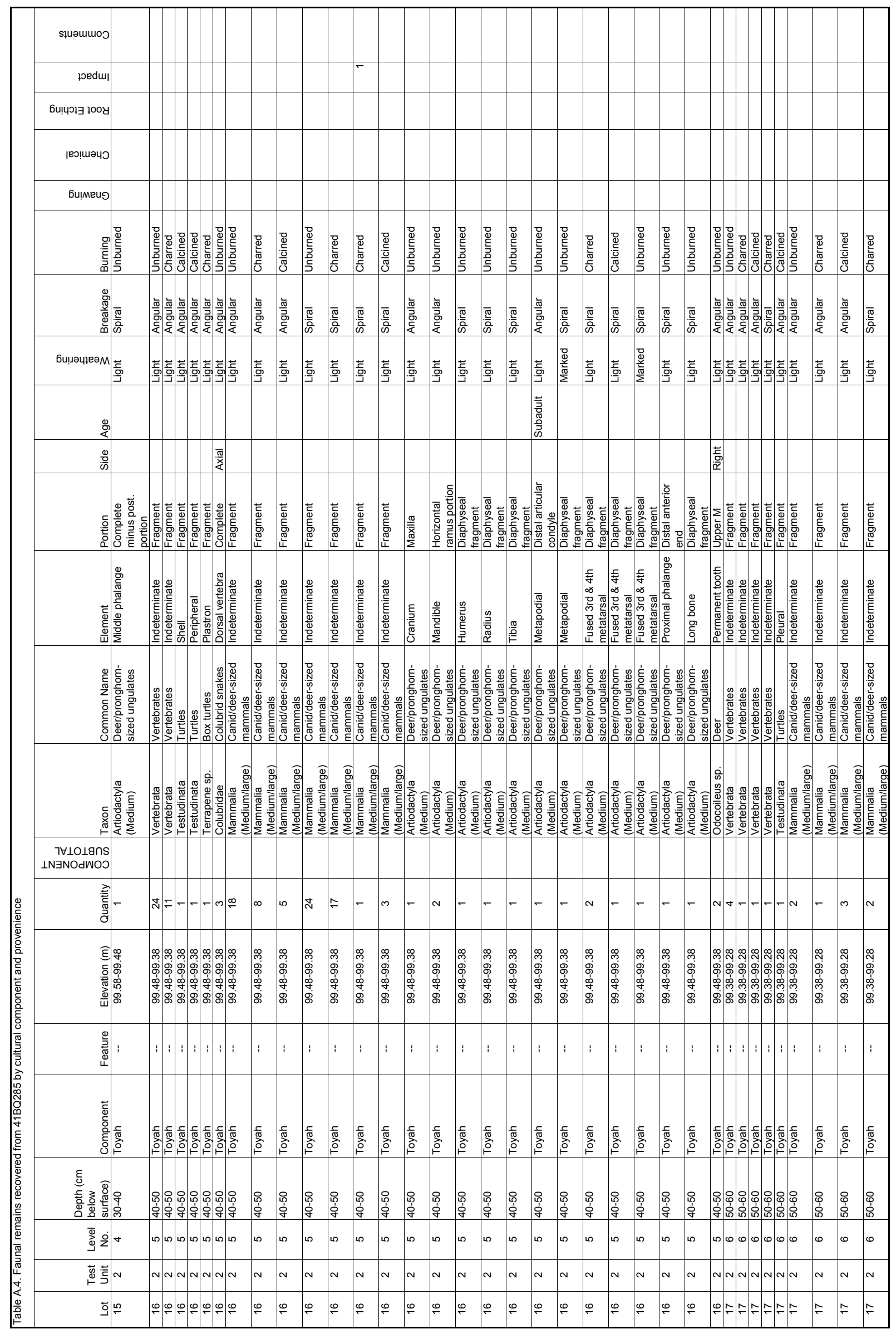




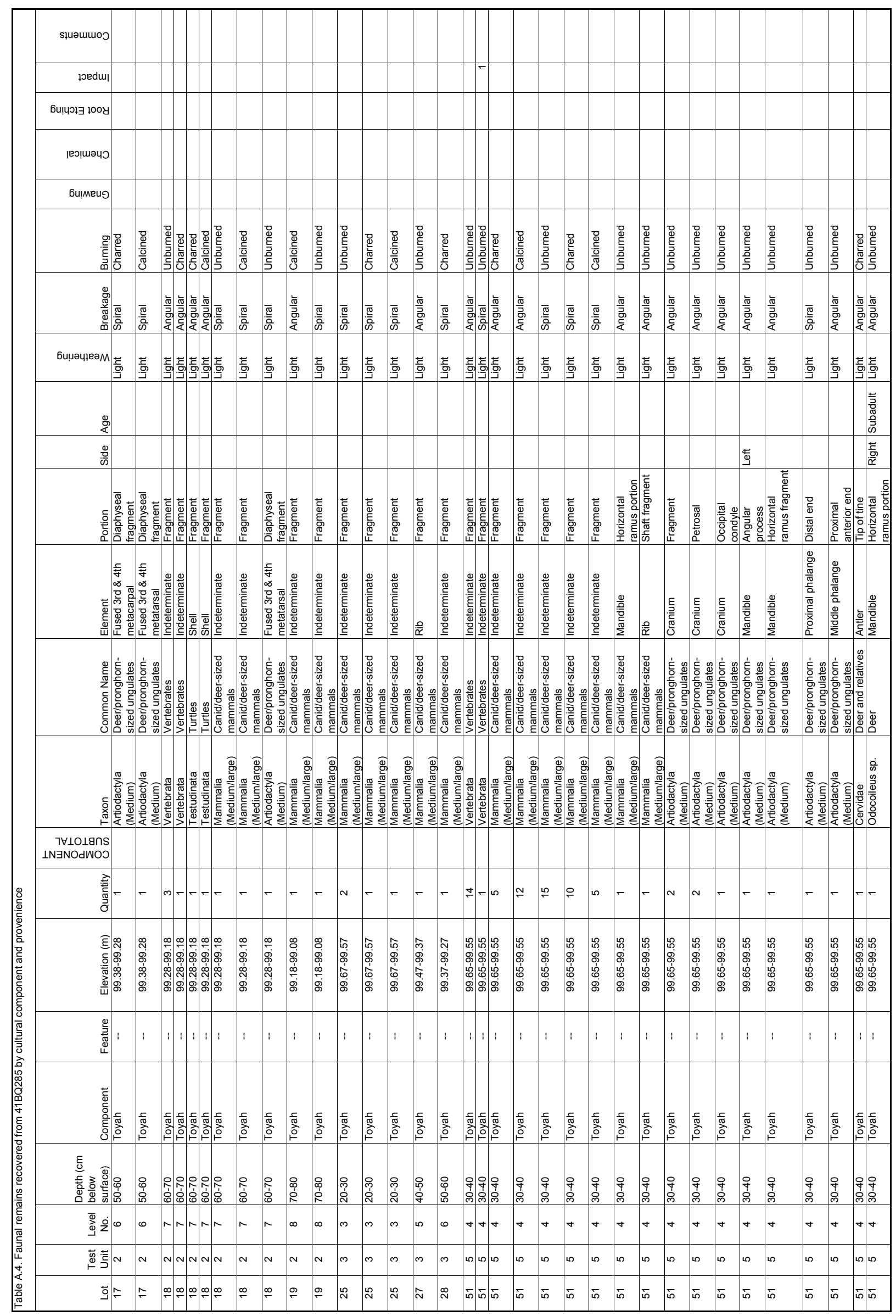




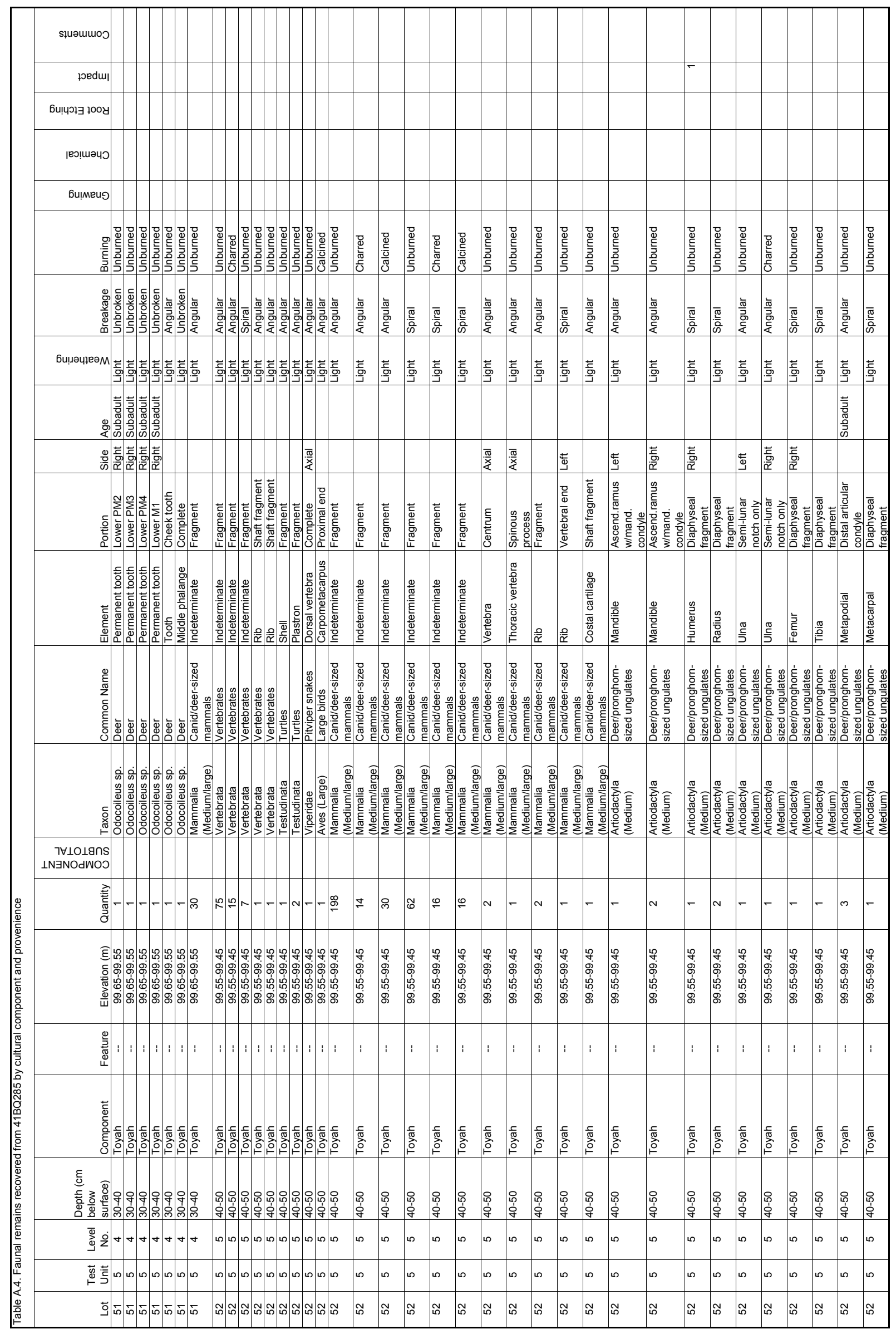




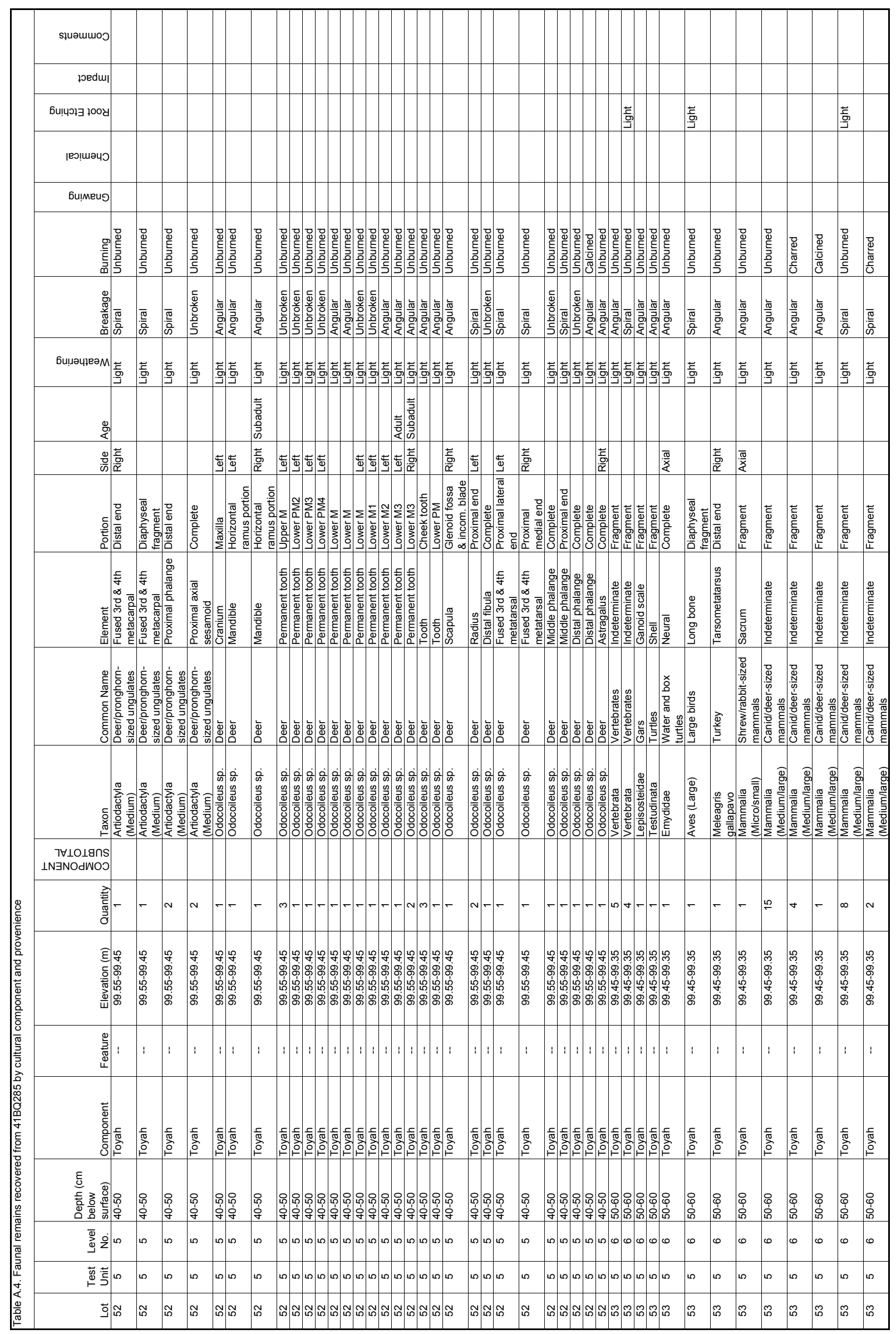




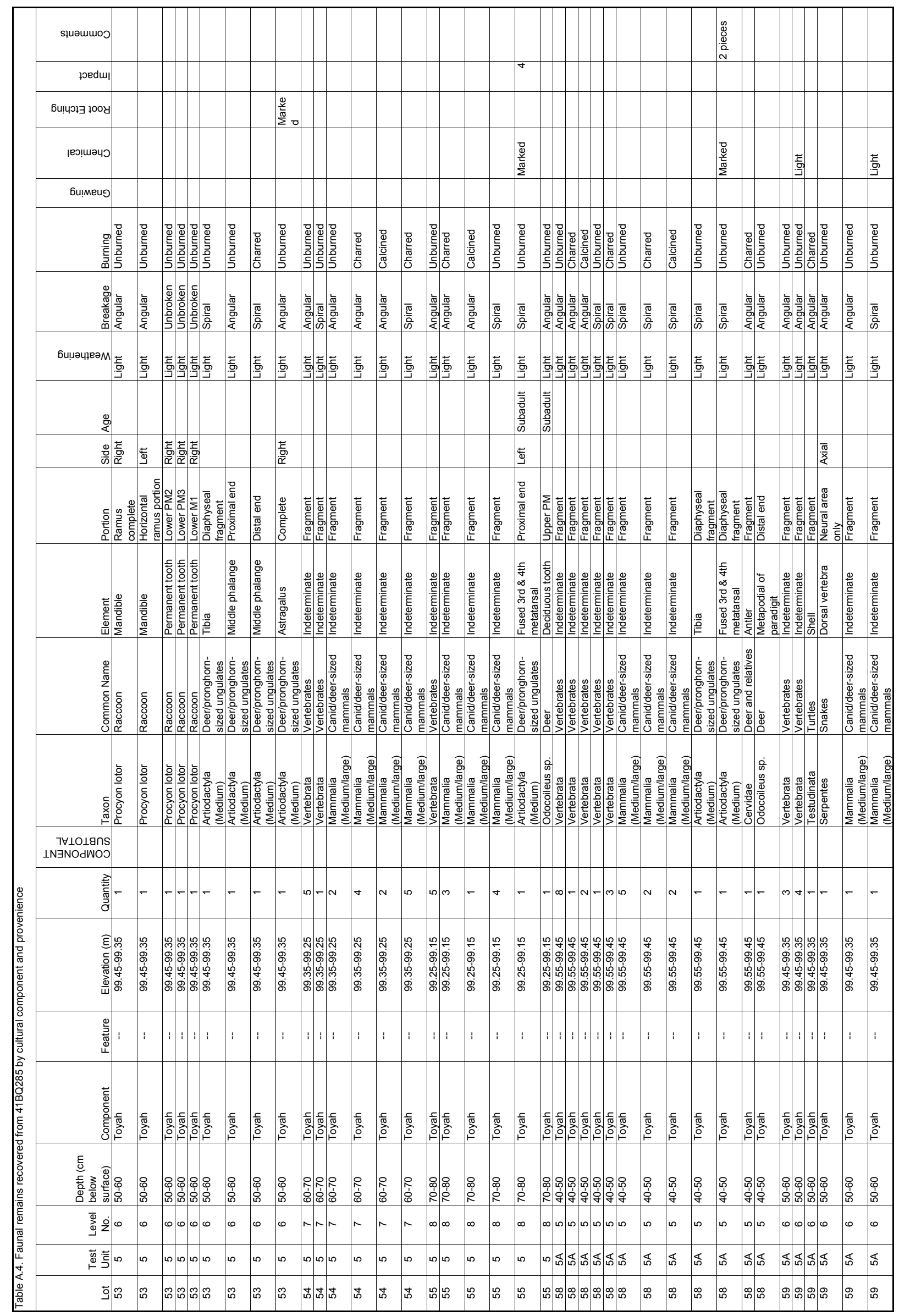




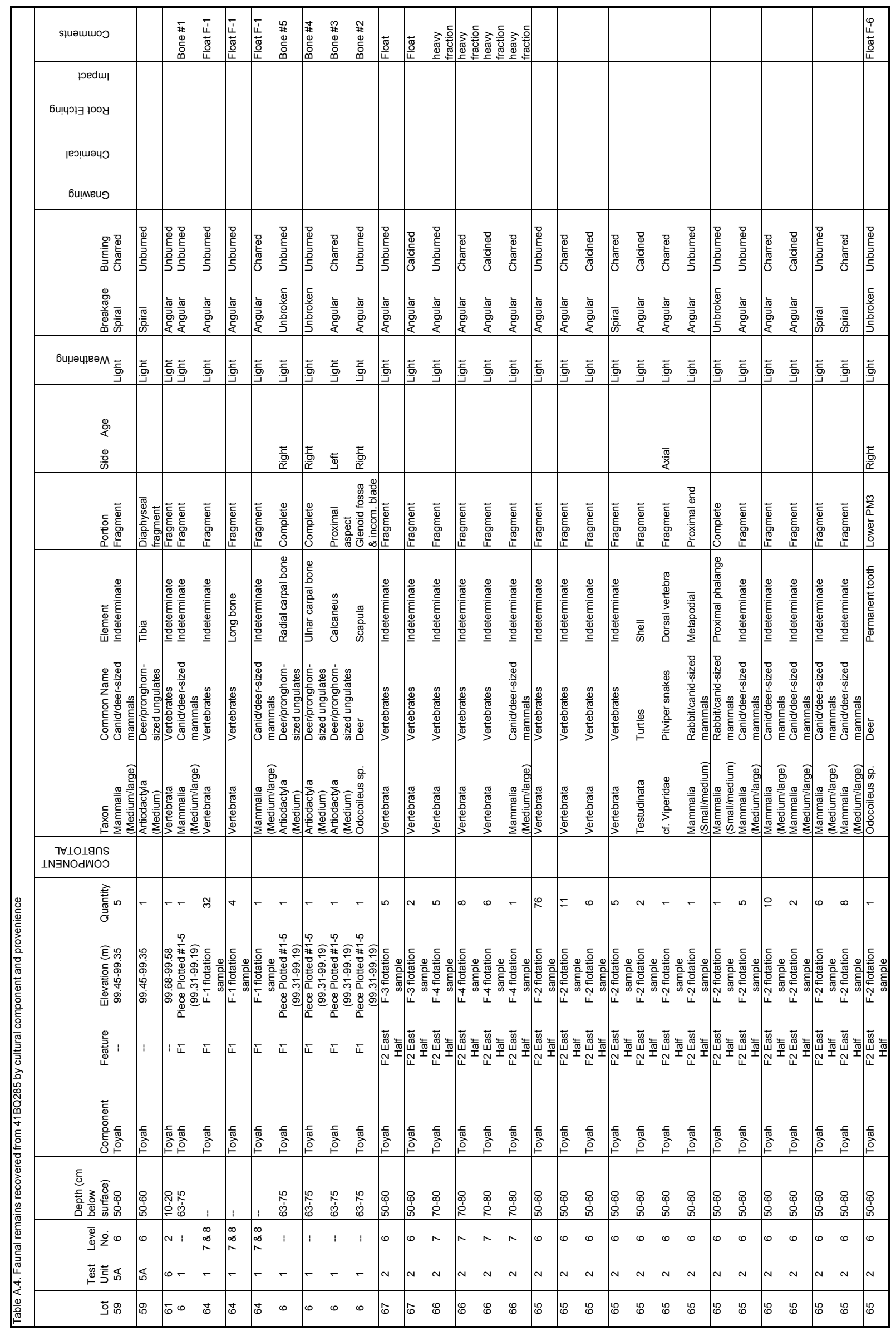




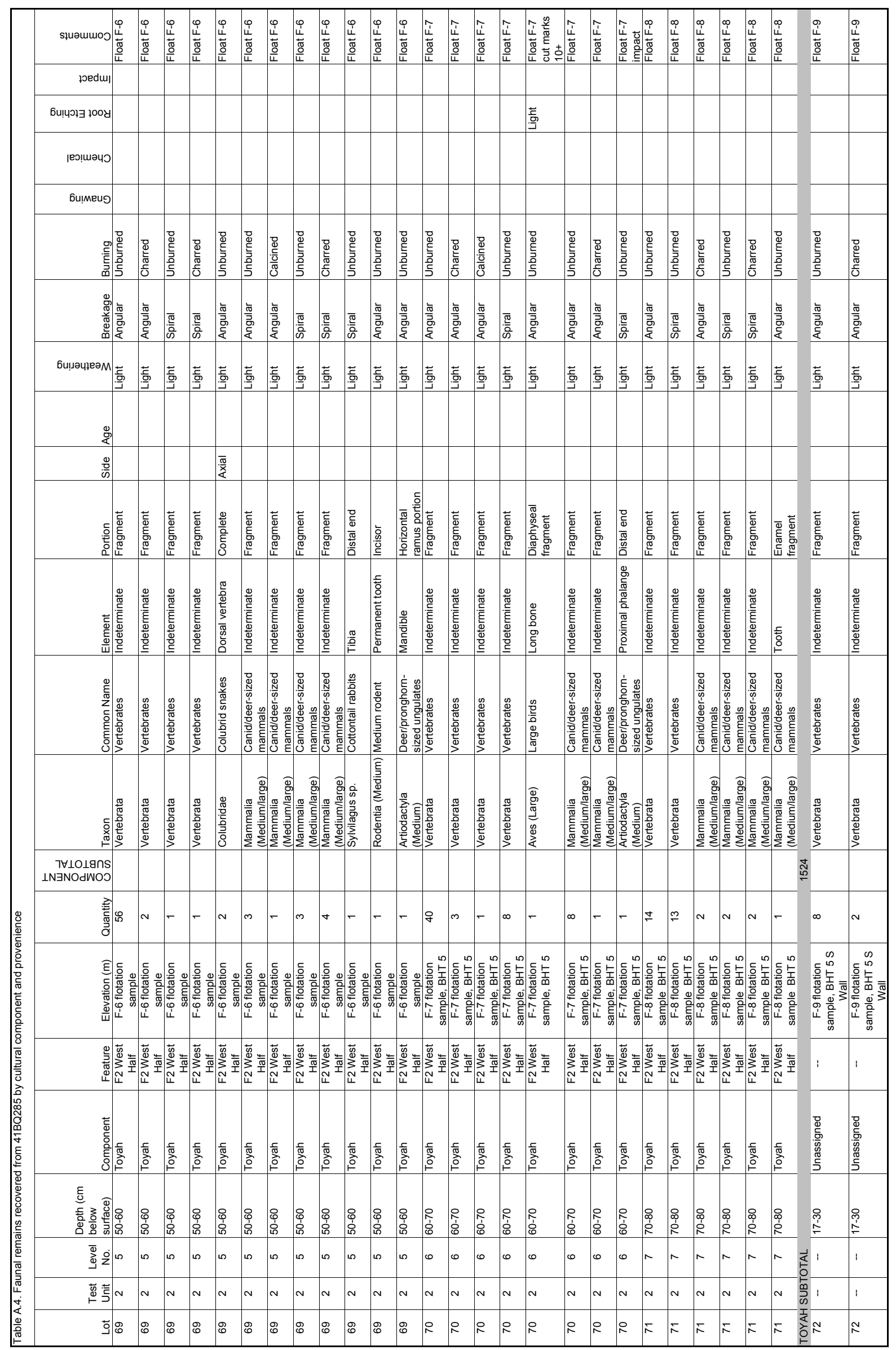




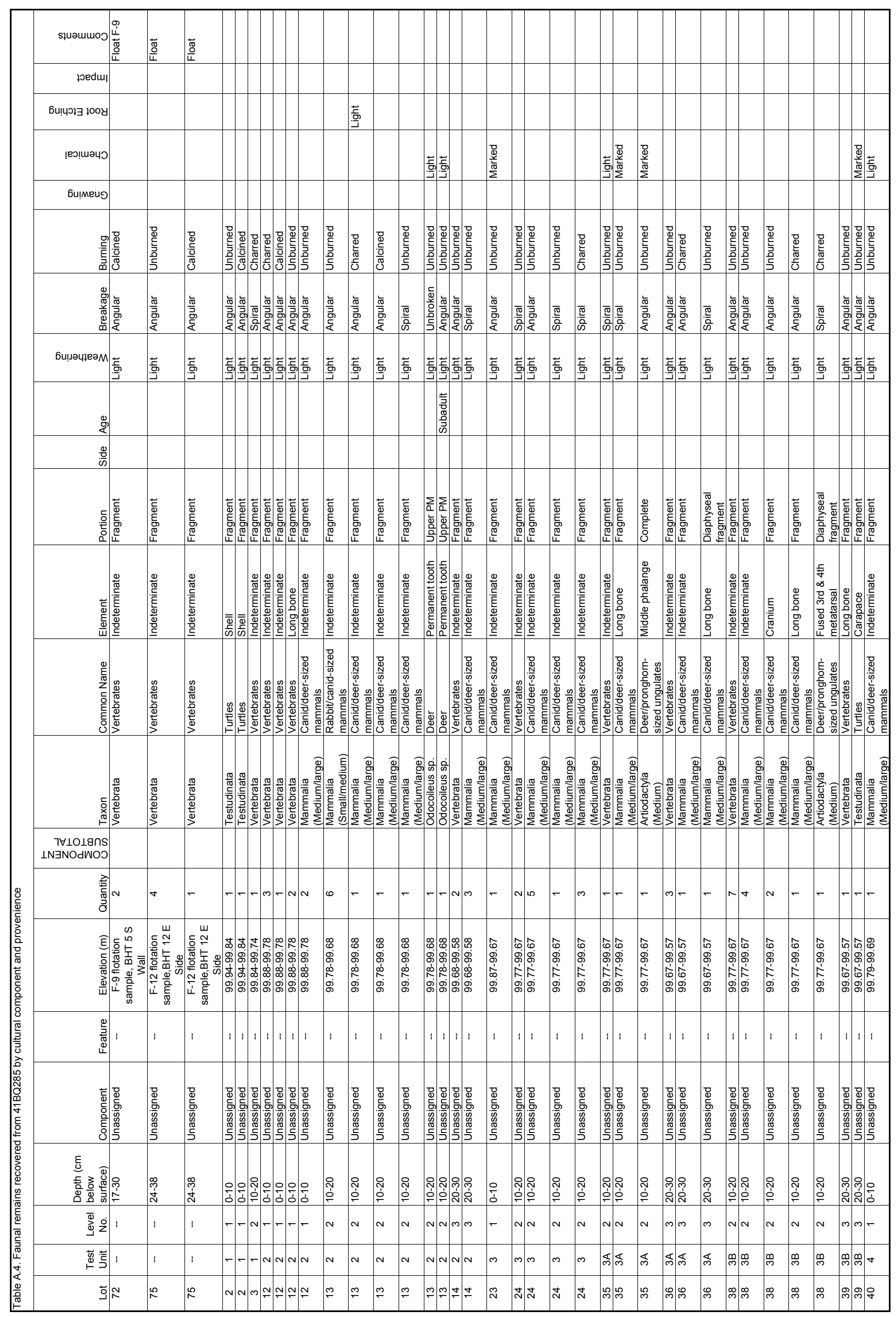


National Register Testing at 41BQ285

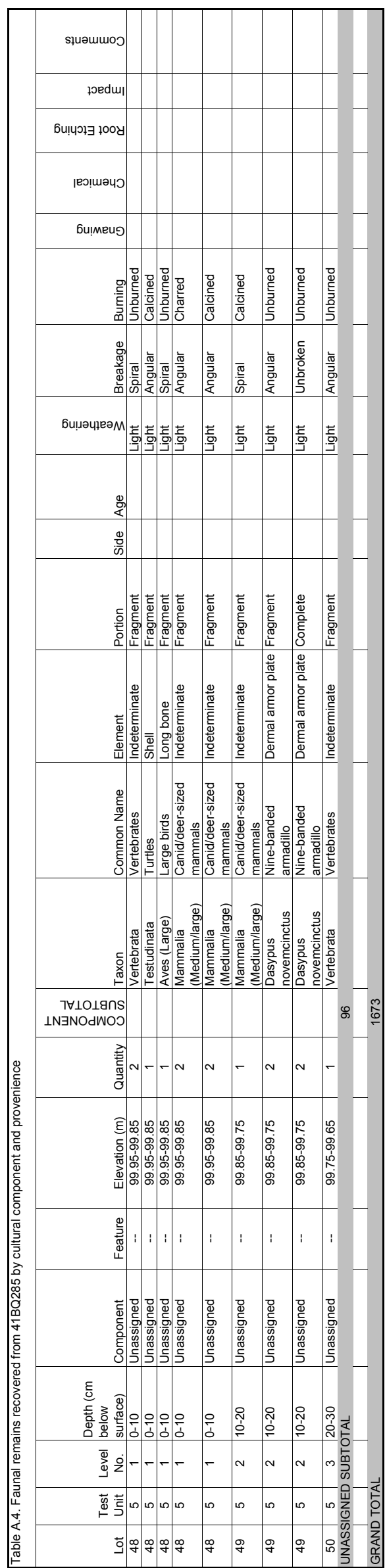




\section{REFERENCES CITED}

Binford, Lewis D.

1978 Nunamiut Ethnoarchaeology. Academic Press, New York.

Church, R. R., and R. L. Lyman

2003 Small Fragments Make Small Differences in Efficiency When Rendering Grease from Fractured Artiodactyl Bones by Boiling. Journal of Archaeological Science 30:1077-1084.

DeMarcay, Gary B.

1986 Vertebrate Fauna from Landergin Mesa: An Antelope Creek Period Village Site. M.A. thesis. Department of Anthropology, Texas A\&M University, College Station, Texas.

Johnson, Eileen

1985 Current Developments in Bone Technology. In Advances in Archaeological Method and Theory, Vol. 8, edited by M. B. Schiffer, pp. 157-235. Academic Press, New York.

Lintz, Christopher R.

1976 The McGrath Site of the Panhandle Aspect. Oklahoma Anthropological Bulletin 25:1-110.
Schmidly, David J.

1983 Texas Mammals East of the Balcones Fault Zone. Texas A\&M Press, College Station, Texas.

Shaffer, Brian S., and Barry W. Baker

1992 A Vertebrate Faunal Analysis Coding System: With North American Taxonomy and dBase Support Programs and Procedures (Version 3.3). Museum of Anthropology, Technical Report No. 23. University of Michigan, Ann Arbor.

Vehik, Susan C.

1977 Bone Fragment and Bone Grease Manufacturing: A Review of the Archaeological Use and Potential. Plains Anthropologist 22:169-182.

Zierhut, N. W.

1967 Bone Breaking Activities of the Calling Lake Cree. Alberta Anthropologist 1:33-36. 

APPENDIX B: Analysis of Macrobotanical Remains

Leslie L. Bush, Ph.D.

Austin, Texas 



\section{INTRODUCTION}

Seven flotation light fractions from Features 1 and 2 collected in test excavations at 41BQ285 were submitted for macrobotanical analysis (Table B.1). Ancient plant remains consisting of wood charcoal, carbonized nutshell, nutmeat, seeds, and fruit rind were recovered and are described here. All of these materials are associated with the Toyah phase component.

\section{SITE SETTING}

Site 41BQ285 is on agricultural land $40 \mathrm{~m}$ north of the North Bosque River in southern Bosque County. The vegetation area is known as the Lampasas Cut Plain, a complex mosaic of vegetation types where grasslands in the east (now primarily cropland) begin to interleave with savanna-like woodlands to the west (McMahon et al. 2007). Whether treated as a northward extension of the Edwards Plateau (Diamond et al. 1987) or a westward extension of the prairies (Diggs et. al 1999; McMahon et al. 2007), the Lampasas Cut Plain supports diverse vegetation. In the east, it tends to be more similar to the Blackland Prairie, and to the west, it is more similar to the Edwards Plateau or Cross Timbers. Topography also plays a role in the diversity of vegetation communities, with areas of soil between larger divides supporting prairie-like communities and slopes and uplands sometimes providing decidedly xeric microclimates (Diggs et al. 1999:53). Many plants of the Edwards Plateau reach the northeasternmost extent of their range in this area (Diggs et al. 1999:54).

Pollen studies indicate that the modern vegetation zones in the area can be used for understanding the plants and attendant animal resources available to occupants of the site dur-

Table B.1. Analyzed flotation samples and their proveniences

\begin{tabular}{c|c}
\hline Sample & Provenience \\
\hline 1 & Feature 1, 70-75 cm below surface \\
\hline 2 & Feature 2, east half, 40-50 cm below surface \\
\hline 3 & Feature 2, east half, $50-60 \mathrm{~cm}$ below surface \\
\hline 4 & Feature 2, east half, $60-70 \mathrm{~cm}$ below surface \\
\hline 6 & Feature 2, west half, $40-50 \mathrm{~cm}$ below surface \\
\hline 7 & Feature 2, west half, $50-60 \mathrm{~cm}$ below surface \\
\hline 8 & Feature 2, west half, $60-70 \mathrm{~cm}$ below surface \\
\hline
\end{tabular}

ing Late Prehistoric times. Weakly Bog, situated in what is now the Post Oak Savannah vegetation region well east of Bosque County, provides some of the best available data for vegetation reconstruction in the region during the last 3,000 years. Pollen profiles from this bog indicate that the area was oak and later oak/hickory woodlands, suggesting that modern plant communities generally provide good analogs for central and eastern Texas plant communities during the last 3,000 years. Some fluctuations in rainfall and/or temperature have taken place, moving the zone of woodland-prairie edge to the east or west (Bousman 1998:204). In his discussion of the data from Boriak and Weakley Bogs, Bousman (1998:208, Figure 5) notes spikes in the grass pollen profiles at 1500 and 500 B.P. The main occupations at 41BQ285, which date to approximately the late thirteenth through early sixteenth or seventeenth centuries A.D., may have occurred during the latter of these two grass spikes, meaning that conditions may have been somewhat drier.

The proximity of the site to the North Bosque River, however, would have buffered some of these broader-scale climactic changes. Stream channels and their attendant floodplains provide uniform habitats in which similar plant communities may be found, even when the stream cuts across very different ecological zones (Lee 1945). Not surprisingly, plants of riparian zones tend to tolerate flooding and other disturbances better than their upland counterparts. Species composition of these forests is partly determined by distance from the stream channel, which indicates the species' requirements for water and/or shade. Species diversity tends to be greater downstream than upstream (Hoagland et al. 1996; Nixon et al. 1990:102). In the upper Trinity River basin, one drainage system to the northeast of the Bosque/ Brazos system, important woody species in the floodplain include elm (Ulmus spp.), hackberry (Celtis spp.), and ash (Fraxinus spp.) (Nixon et al. 1990:102). To the southeast, Ricklis and Collins (1994:33) list oak, walnut, hackberry, sumac, bald cypress, and cottonwood as the dominant arboreal vegetation in the larger stream valleys of the Blackland Prairie. Most of these genera 
were recovered among the wood charcoal at 41BQ285.

\section{METHODS}

The flotation samples were processed at Prewitt and Associates, Inc., in a Flote-Tech flotation machine with bottom mesh openings of $1.0 \mathrm{~mm}$ (Dausman 1989; Hunter and Gassner 1998; Rossen 1999). Light fractions were submitted for sorting and analysis. Samples were sorted in the author's laboratory in Austin. Each flotation light fraction was weighed on an electronic balance with a sensitivity of $0.01 \mathrm{~g}$ before being size-sorted through a stack of geologic mesh with openings of $2,1.4$, and $0.71 \mathrm{~mm}$. Materials in the $>2$-mm size fraction were completely sorted, and all carbonized botanical remains and potentially identifiable faunal remains were counted, weighed, recorded, and labeled. In all samples except one (the Feature 1 sample, where only 9 fragments were present), the number of wood charcoal fragments was estimated based on the weight of 50 randomly selected fragments. Materials other than carbonized botanical remains in the $>2$-mm size fraction were weighed, recorded, and labeled but not counted. All materials in the $>2$-mm size fraction other than bones and charred plants are referred to as "contamination." Materials that fell through the 2-mm mesh, referred to as "residue," were examined under a stereoscopic microscope at 7-45x magnification for charred botanical remains other than nutshell, wood charcoal, and bulb fragments. All plant material removed from the residue was counted, weighed, and labeled. The presence of uncharred taxa in the residue also was recorded on laboratory forms, but these materials were not usually removed from residue.

For each sample except that from Feature 1, 20 wood charcoal fragments were selected at random from those larger than $2 \mathrm{~mm}$, with large and small fragments chosen alternately. All 9 fragments from Feature 1 were identified. Fragments were snapped to reveal a transverse section and examined under a stereoscopic microscope at 28-180x magnification. When necessary, tangential or radial sections were examined for ray seriation, presence of spiral thickenings, types and sizes of intervessel pitting, and other minute characteristics that can only be seen at higher magnifications (Hoadley 1990; Panshin and deZeeuw 1980).
Botanical materials were identified to the lowest possible taxonomic level by comparison to materials in the author's comparative collection and through the use of standard reference works (e.g., Davis 1993; Hoadley 1990; Martin and Barkley 1961; Musil 1963; Panshin and deZeeuw 1980; Schopmeyer 1974). In some cases, botanical remains could be identified to the level of the species through positive identification or elimination of other members of the genus (e.g., Platanus occidentalis). Most commonly botanical materials were identified to the level of genus, but sometimes only family identification was possible. Botanical nomenclature and common names follow Diggs et al. (1999) except in the cases where the name in archeological use differs significantly from the name used in that source.

\section{RESULTS}

The uncarbonized botanical remains recovered through flotation are shown in Table B.2. Carbonized plant remains are shown in Tables B. 3 and B. 4 by count and weight.

\section{Uncarbonized Plant Remains}

Uncarbonized seeds and rootlets are a common occurrence on most archeological sites. They usually represent modern plants that have made their way into the soil either through their own dispersal mechanisms or by faunalturbation, floralturbation, or argilliturbation (Bryant 1985:51-52; Keepax 1977; Miksicek 1987:231-232). In all except the driest areas of North America, uncarbonized plant material found at open-air sites can be assumed to be of modern origin unless compelling evidence suggests otherwise (Lopinot and Brussell 1982; Miksicek 1987:231). Although the uncarbonized plants from 41BQ285 are almost certainly modern, the greater than usual overlap between carbonized and noncarbonized plant types and the good faunal preservation at the site make consideration of the uncarbonized remains less trivial than usual for an open site. Further complicating the issue is the presence of some incompletely carbonized wood and one incompletely carbonized chenopodium fruit in Feature 2.

Despite these considerations, several lines of evidence lead to the conclusion that uncarbonized plants at 41BQ285 are modern. First is the 
Table B.2. Uncarbonized botanical remains

\begin{tabular}{|c|c|c|c|c|c|c|c|c|}
\hline Sample number & 1 & 2 & 3 & 4 & 6 & 7 & 8 & Total \\
\hline Feature & 1 & 2 & 2 & 2 & 2 & 2 & 2 & \\
\hline Rootlets & $\mathrm{X}$ & $\mathrm{X}$ & $\mathrm{X}$ & $\mathrm{X}$ & $\mathrm{X}$ & $\mathrm{x}$ & $\mathrm{x}$ & 7 \\
\hline Roots $>3 \mathrm{~mm}$ & $\mathrm{X}$ & $\mathrm{X}$ & & $\bar{X}$ & $\mathrm{X}$ & $\mathrm{X}$ & $\mathrm{x}$ & 6 \\
\hline Hackberry seed & & $\mathrm{X}$ & $\mathrm{X}$ & $\mathrm{X}$ & $\mathrm{X}$ & $\mathrm{X}$ & $\mathrm{X}$ & 6 \\
\hline Grass seed & & & $\mathrm{X}$ & & $\mathrm{X}$ & $\mathrm{X}$ & $\mathrm{X}$ & 4 \\
\hline $\begin{array}{l}\text { Chenopodium } \\
\text { seed }\end{array}$ & & & $\mathrm{X}$ & & $\mathrm{X}$ & $\mathrm{X}$ & $\mathrm{X}$ & 4 \\
\hline Pokeweed seed & & $\mathrm{X}$ & & & $\mathrm{X}$ & & $\mathrm{X}$ & 3 \\
\hline Copperleaf seed & & & & $\mathrm{X}$ & & $\mathrm{X}$ & $\mathrm{X}$ & 3 \\
\hline Bark & $\mathrm{X}$ & $\mathrm{X}$ & & & & $\mathrm{X}$ & & 3 \\
\hline Pecan shell & & $\mathrm{X}$ & & & & & $\mathrm{X}$ & 2 \\
\hline Grass stem & & & $\mathrm{X}$ & & & $\mathrm{X}$ & & 2 \\
\hline Leaf & & & & $\mathrm{X}$ & & & & 1 \\
\hline Knotweed seed & & $\mathrm{X}$ & & & & & & 1 \\
\hline$\overline{\text { Bud }}$ & & $\mathrm{X}$ & & & & & & 1 \\
\hline
\end{tabular}

Other Disturbance Indicators

\begin{tabular}{l|l|l|l|l|l|l|l|l|l}
\hline Gastropods & $\mathrm{X}$ & $\mathrm{X}$ & $\mathrm{X}$ & $\mathrm{X}$ & $\mathrm{X}$ & $\mathrm{X}$ & $\mathrm{X}$ & & 7 \\
\hline Insects & $\mathrm{X}$ & & & & $\mathrm{X}$ & $\mathrm{X}$ & $\mathrm{X}$ & & 4 \\
\hline Insect sign & $\mathrm{X}$ & & & $\mathrm{X}$ & & & & & 2 \\
\hline
\end{tabular}

Fauna

\begin{tabular}{l|c|c|c|c|c|c|c|c|c}
\hline Fish scale & $\mathrm{X}$ & & & & & & $\mathrm{X}$ & & 2 \\
\hline Bone & & $\mathrm{X}$ & $\mathrm{X}$ & $\mathrm{X}$ & $\mathrm{X}$ & & $\mathrm{X}$ & 5 \\
\hline Mussel shell & & & $\mathrm{X}$ & & $\mathrm{X}$ & $\mathrm{X}$ & & & 3 \\
\hline
\end{tabular}

shallow nature of the archeological deposits. Flotation samples were taken from features in active soil horizons and not from the anaerobic or undisturbed environments that would allow floral preservation over long periods of time. Second, the presence of disturbance indicators such as rootlets, insects, and gastropods in all levels of the features sampled shows the potential for modern plants to move into these levels, as well as the potential for uncarbonized seeds to be subject to predation by small animals. Finally, there is not a clear continuum between carbonized and uncarbonized plants at the site, with only eight fragments of wood charcoal and one fruit falling between the carbonized and uncarbonized categories. These incompletely carbonized specimens are treated here as ancient, largely because no uncarbonized fragments of wood were recovered from the site, other than cylindrical fragments that were clearly modern roots. It is possible that these few specimens are modern, as noted in Tables B.2 and B.3. The taxa they represent were also recovered in completely carbonized form, and their inclusion among the ancient remains does not significantly impact interpretation of the plant remains from 41BQ285. Finally, it should be noted that the carbonized plant remains have been demonstrated to be associated with the archeological deposits: five radiocarbon dates on carbonized plant material returned results indicating tissue death in the late thirteenth through early seventeenth centuries.

The uncarbonized flora at 41BQ285 thus do not appear to reflect extraordinary survival of ancient specimens. Rather, the overlap between carbonized and uncarbonized flora at the site should be taken to indicate continuity 


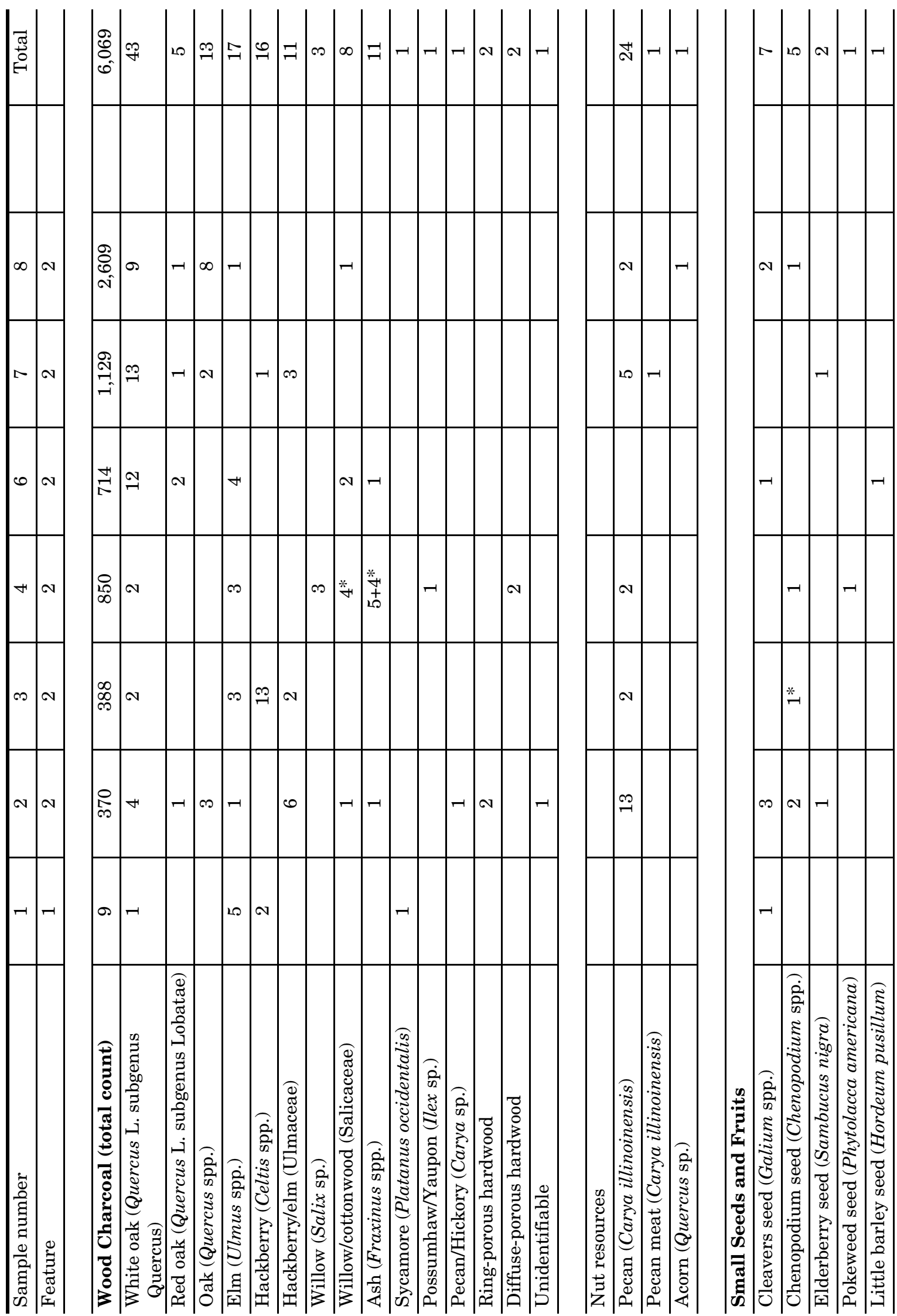


Appendix B: Analysis of Macrobotanical Remains

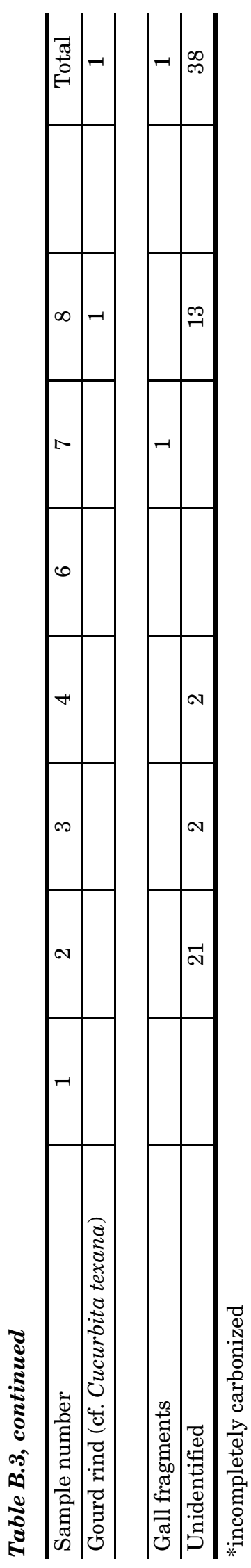




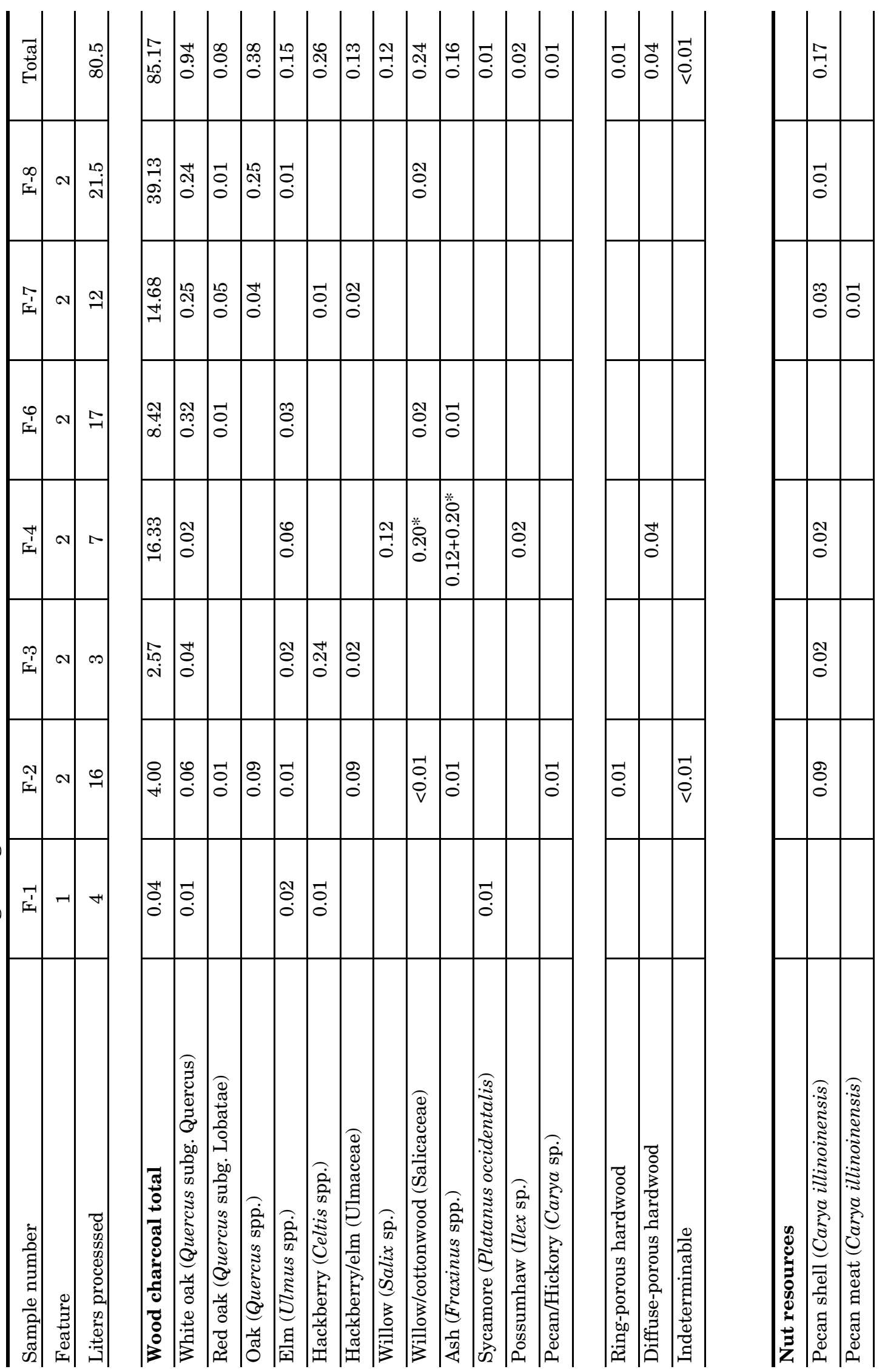


Appendix B: Analysis of Macrobotanical Remains

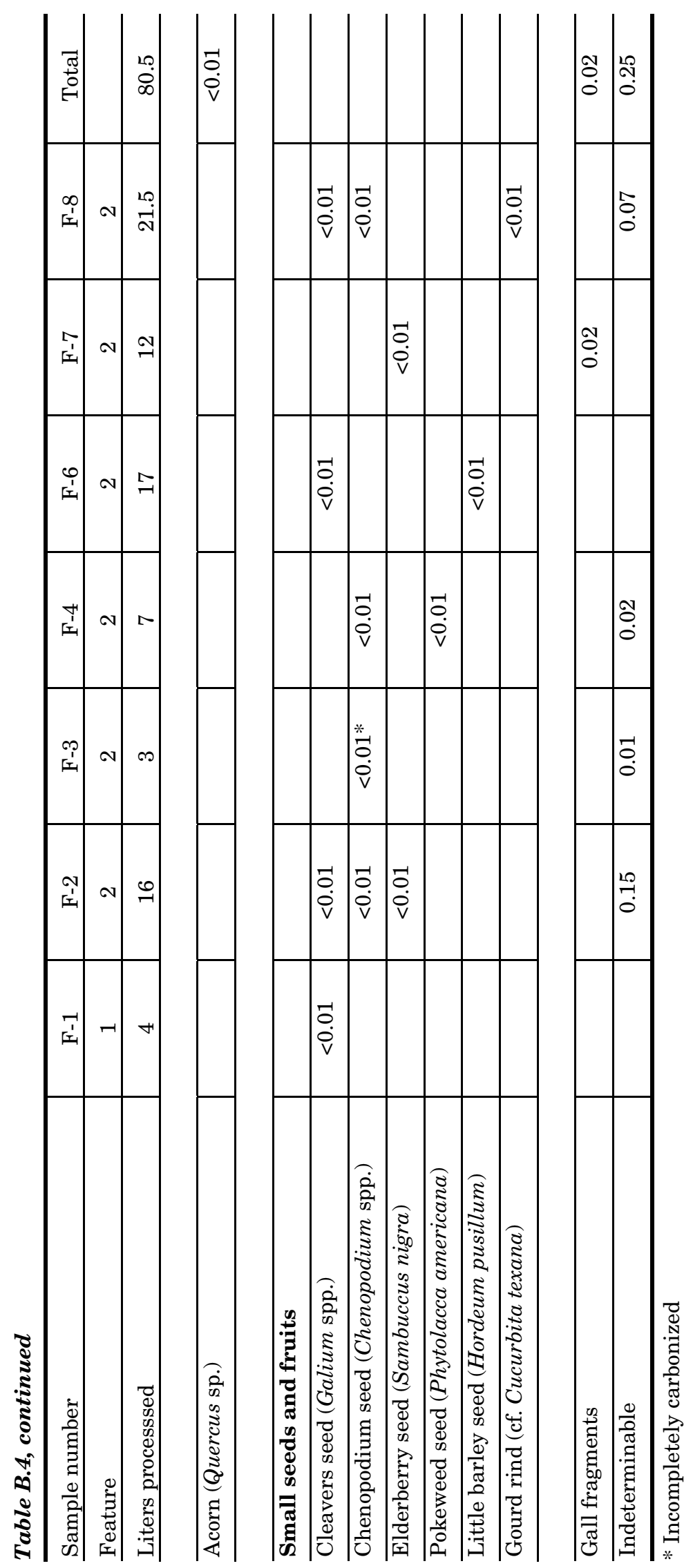


of vegetation types in the site area over the last 800 years, especially along the North Bosque River. Although settlement by pastoralists and agriculturalists has wrought great changes in the areas suitable for plowing and grazing, steep slopes and areas adjacent to smaller streams have been more protected-but not immune-from loss of once-common species. As the ancient plant remains from 41BQ285 indicate, many plants used by people living along the North Bosque River in Late Prehistoric times are also those recorded on central Texas rivers by early settlers and are still sometimes present there today.

\section{Carbonized Plant Remains}

\section{Wood Charcoal}

The most common carbonized plant type found in the samples from 41BQ285 is wood charcoal. Identification was attempted for 135 fragments of wood charcoal, and 130 of these were identifiable to the family level or better. As shown in Table B.3, nearly half (45 percent) of the identified wood charcoal fragments are oak. Both red and white groups of oak are present. Post oak (Quercus stellata), a tree of the uplands, is the most common white oak of the white group in the eastern two-thirds of Texas, but bur oak (Q. macrocarpa) and other white oaks occur along streams in north-central Texas (Diggs et al. 1999). Blackjack oak (Q. marlandica) is a common red oak in the Lampasas Cut Plain; red oaks are not as common along streams in central Texas. Oaks are particularly valuable as firewood because they burn at high temperatures and produce hot, long-lasting coals (Graves 1919).

Elm and hackberry make up more than a third (34 percent) of the identified wood charcoal assemblage. Neither are particularly notable for their firewood, which is difficult to split, slow to dry, and tends to smolder (Hanley 2002). The inner bark of many elms, however, is valuable for cordage (Gilmore 1991:24). Both elm and hackberry are common along streams, as are willows and cottonwood, which contribute 8 percent of the wood charcoal. The low specific gravity of willow and cottonwood means they produce little heat when burned (Graves 1919). They also tend to throw off sparks (Hanley 2002).

Ash, another genus that grows along streams in north-central Texas, makes up 8 percent of the wood charcoal. The three species in north-central Texas are white ash (Fraxinus americana), green or red ash ( $F$. pennsylvanica), and Texas ash (F. texensis). These can be extremely valuable firewoods because they are among the few woods that will light when green. The remaining 2 percent of the wood charcoal at $41 \mathrm{BQ} 285$ is sycamore, possumhaw or yaupon, and pecan or hickory.

\section{Carbonized Nutshell}

Nut resources reflected in the archeological deposits at 41BQ285 duplicate the nut-bearing trees represented in the wood charcoal, although not in the same proportions. All but one of the nutshell or nutmeat fragments recovered (96 percent) is pecan, a tree whose genus is represented by only one fragment of wood charcoal (less than 1 percent of the identified specimens; hickory and pecan are both members of the genus Carya, and species distinctions in the wood tissue rely on examination of the earlywood portion of the growth ring, which was not present in this specimen). A single fragment of oak was recovered from Feature 2. The relative proportions of oak and pecan make sense given the probable economic uses of the plants. Oak is generally a better firewood than pecan, and pecan nut meats are more efficiently exploited for food than acorns, which are starchy. Pecan meats contain more oil and therefore yield more calories per nut than the starchy acorns (Petruso and Wickens 1984). Furthermore, pecans can be cracked, picked (or boiled for their oil), and eaten raw (Hall 2000). All oaks contain tannins, which can be toxic in large quantities, and red oaks generally have more tannins than white oaks (Diggs et al. 1999). The acorns are usually leached of tannins before consumption by boiling or soaking in water, although instances of consumption of raw acorns by Native Americans have been recorded (Gilmore 1991:23; Moerman 1998; Ortiz and Parker 1991; Tull 1999).

\section{Carbonized Small Seeds and Fruits}

Five small seeds and one fruit rind were recovered from the flotation samples. All but one are weedy annuals that thrive in disturbed conditions such as streamsides and areas associated with human habitation. The exception 
is elderberry, a perennial shrub. Although it is not an annual plant that adapts quickly to changing circumstances, it does prefer stream bottoms and ditch banks and so is likely to have been present in the vicinity of the site (Diggs et al. 1999:510).

Five of the six small seeds or fruits represented at the site have common food uses. The young greens of chenopodium and pokeweed can be eaten without processing. Although elderberry and pokeweed contain toxins, authorities agree that they can be safely eaten when cooked; they differ on whether or not the fruits are edible raw (see Deam 1940:434; Diggs 1999:510, 881-882; Moerman 1998:397-398, 510-515). Because of this toxicity, leaves, bark, and roots of elderberry and pokeweed have many medicinal uses (Moerman 1998:397-398, 510-515). Dry chenopodium fruits are definitely edible raw, although their thick seedcoat makes them less palatable than the fleshy fruits of elderberry and pokeweed. The domesticated varieties of chenopodium developed independently by people in eastern North America (Chenopodium berlandieri var. jonesianum) and South America (Chenopodium quinoa) exhibit a significant thinning of the seedcoat, reducing germination time for the plant and increasing palatability of its fruit (Smith 1995:23, 172, 187). Two other seeds recovered from the samples are also edible. Like many grass seeds, the starchy grains of little barley may be eaten, usually after boiling. Oily gourd seeds, of which pepitos are a modern example, are edible raw or toasted. Archeologists have long speculated that consumption of gourd seeds may have been the original reason for intensive use that eventually led to the do- mestication of gourds (e.g., Whitaker and Cutler 1986). Wild gourd rind is often too fragile for heavy use, but it is used to make containers, ladles, and musical instruments (Moerman 1998:187-188; see also figures in Harriot 1972, especially Figure 3 and Plates XVII and XVIII, for depictions of these uses by sixteenth-century explorers on the east coast of North America).

Cleavers, the only small seed recovered with no known food uses, was present in every sample examined. These fruits are burs, and their presence on archeological sites is usually interpreted as accidental or as a result of the immediate disposal of a nuisance plant by fire. They are therefore useful to archeologists as an indicator of site occupation (Munson and Bush 2007). North-central Texas species of the cleavers genus flower in the spring (March through June) and fruit in the late spring and early summer (mostly April through July), indicating that the trash disposal events in Features 1 and 2 occurred during a late spring or summer occupation of the site (Diggs et al. 1999:964-966).

\section{SUMMARY}

Ancient plant remains recovered from 41BQ285 are plants that were likely present in the immediate site area. With the exception of the cleavers, the plants recovered have economic uses that may have been important to the site inhabitants. The carbonized flora thus reflect use of resources in the immediate vicinity, and they suggest no intensive or long-term occupation that would require transportation of common plant resources from outside the floodplain of the North Bosque River. 


\section{REFERENCES CITED}

Bousman, C. Britt

1998 Paleoenvironmental Change in Central Texas: The Palynological Evidence. Plains Anthropologist 43(164):201-219.

Bryant, John A.

1985 Seed Physiology. The Institute of Biology's Studies in Biology No. 165. Edward Arnold, Ltd., London.

Dausman, Raymond J.

1989 Multimodal Flotation. Wisconsin Archaeologist 70(3):362-366.

Davis, Linda W.

1993 Weed Seeds of the Great Plains: A Handbook for Identification. University Press of Kansas, Lawrence.

Deam, Charles C.

1940 Flora of Indiana. Department of Conservation, Division of Forestry. Reprinted 2002 by The Blackburn Press., Indianapolis, Indiana.

Diamond, David D., David H. Riskind, and Steve L. Orzell

1987 A Framework for Plant Community Classification and Conservation in Texas. The Texas Journal of Science 39(3):203-221.

Diggs Jr., George M., Barney L. Lipscomb, and Robert J. O'Kennon

1999 Shinners and Mahler's Illustrated Flora of North Central Texas. Botanical Research Institute of Texas, Fort Worth.

Gilmore, Melvin R.

1991 Uses of Plants by the Indians of the Missouri River Region. originally published 1919. University of Nebraska Press, Lincoln and London.

Graves, Henry S.

1919 The Use of Wood for Fuel. U.S. Department of Agriculture Bulletin No. 753. U.S. Department of Agriculture, Washington, D.C.

Hall, Grant D.

2000 Pecan Food Potential in Prehistoric North America. Economic Botany 54(1):103-112.

Hanley, Donald P.

2002 Firewood Selection. In Wood as a Fuel. University of Idaho Extension Service. UI Extension Forestry Information Series
CNR-CD No. 1. Available at http://www. cnr.uidaho.edu/extforest/SearchTopics. htm [PDF file].

Harriot, Thomas

1972 A Briefe and True Report of the New Found Land of Virginia. Originally published 1588. Translated and with an introduction by Paul Hulton. Dover Publications, Inc., New York.

Hoadley, R. Bruce

1990 Identifying Wood: Accurate Results with Simple Tools. The Taunton Press, Newtown, Connecticut.

Hoagland, Bruce W., Lisa R. Sorrets, and Susan M. Glenn

1996 Woody Species Composition of Floodplain Forests of the Little River, McCurtain and LeFore Counties, Oklahoma. Proceedings of the Oklahoma Academy of Sciences 76:23-29.

Hunter, Andrea A., and B. R. Gassner

1998 Evaluation of the Flote-Tech MachineAssisted Flotation System. American Antiquity 63(1):127-132.

Keepax, Carole

1977 Contamination of Archaeological Deposits by Seeds of Modern Origin with Particular Reference to the Use of Flotation Machines. Journal of Archaeological Science $4: 221-229$

Lee, Mordie B.

1945 An Ecological Study of the Floodplain Forest Along the White River System of Indiana. Butler University Botanical Studies 7:155-175.

Lopinot, Neal H., and David Eric Brussell

1982 Assessing Uncarbonized Seeds from Open-air Sites in Mesic Environments: An Example from Southern Illinois. Journal of Archaeological Science 9:95-108.

Martin, Alexander C., and William D. Barkley 1961 Seed Identification Manual. University of California Press, Berkeley.

McMahon, Craig A., Roy G. Frye, and Kirby L. Brown 2007 Cross Timbers and Prairies Ecological Region. Available at http://www.tpwd. state.tx.us/landwater/land/habitats/ cross_timbers/ecoregions/cross_timbers. phtml. Texas Parks and Wildlife Department, Austin. 
Miksicek, Charles H.

1987 Formation Processes of the Archaeobotanical Record. In Advances in Archaeological Method and Theory, Vol. 10, edited by Michael B. Schiffer, pp. 211-247. Academic Press, Inc.

Moerman, Daniel E.

1998 Native American Ethnobotany. Timber Press, Portland, Oregon.

Munson, Patrick J., and Leslie L. Bush

2007 Look What the Cat Brought In: Burs as Seasonal Indicators on Archaeological Sites in Temperate Eastern North America. Paper presented at the Roald Fryxell Symposium, 72nd Annual Meeting of the Society for American Archaeology, Austin, Texas.

Musil, Albina F.

1963 Identification of Crop and Weed Seeds. Agriculture Handbook No. 219. U.S. Department of Agriculture, Washington, D.C.

Nixon, Elray S., Gene A. Sullivan, Stanley D. Jones, Gretchen D. Jones, and Jenny K. Sullivan 1990 Species Diversity of Woody Vegetation in the Trinity River Basin, Texas. Castanea 55(2):97-105.

Ortiz, Beverly R., and Julia F. Parker

1991 It Will Live Forever: Traditional Yosemite Indian Acorn Preparation. Heyday Books, Berkeley.

Panshin, A. J., and Carol de Zeeuw

1980 Textbook of Wood Technology: Structure, Identification, Properties, and Uses of the Commercial Woods of the United States and Canada. Fourth ed. McGraw-Hill Book Company, New York.
Petruso, Karl M., and Jere M. Wickens

1984 The Acorn in Aboriginal Subsistence in Eastern North America: A Report on Miscellaneous Experiments. In Experiments and Observations on Aboriginal Wild Plant Food Utilization in Eastern North America, edited by Patrick J. Munson, pp. 360-378. Volume VI, Number 2. Indiana Historical Society, Indianapolis.

Ricklis, Robert A., and Michael B. Collins

1994 Archaic and Late Prehistoric Human Ecology in the Middle Onion Creek Valley, Hays County, Texas. Studies in Archeology Studies in Archeology 19. 2 vols. Texas Archeological Research Laboratory, The University of Texas at Austin.

Rossen, Jack

1999 The Flote-Tech Flotation Machine: Messiah or Mixed Blessing? American Antiquity 64(2):370-372.

Schopmeyer, C. S.

1974 Seeds of Woody Plants in the United States. Agricultural Handbook No. 450. U.S. Department of Agriculture, Washington, D.C.

Smith, Bruce D.

1995 The Emergence of Agriculture. Scientific American Library, New York.

Tull, Delena

1999 Edible and Useful Plants of Texas and the Southwest. University of Texas Press, Austin.

Whitaker, T. W., and H. C. Cutler

1986 Cucurbits from Preceramic Levels at Guila Naquitz. In Guild Naquitz, Archaic Foraging and Early Agriculture in Oaxaca, Mexico, edited by K. V. Flannery, pp. 275-279. Academic Press, Orlando. 



\section{APPENDIX C: Analysis of Aboriginal Ceramic Sherds}

Timothy K. Perttula, David G. Robinson, Jeffrey R. Ferguson, and Michael D. Glascock 



\section{INTRODUCTION}

\section{Timothy K. Perttula}

Five aboriginal ceramic sherds from 41BQ285 on the North Bosque River in Bosque County, Texas, are the subject of technological and stylistic analysis, petrographic analysis (see Robinson, below), and instrumental neutron activation analysis (see Ferguson and Glascock, below). The purpose of these analyses is to characterize these few sherds with respect to their technological, stylistic, petrographic, and geochemical diversity, and also to establish if these sherds are from vessels manufactured locally or extra-locally. Specifically, we propose to establish if the sherds from 41BQ285 are from vessels made in the Caddo area of East Texas, another part of central Texas, or were made in the general vicinity of the site. Past stylistic, petrographic, and geochemical studies of central Texas ceramic sherds provide the comparative ceramic database (see Neff and Glascock 2005; Perttula et al. 2003).

\section{TECHNOLOGICAL AND STYLISTIC ANALYSES}

The five sherds from 41BQ285 that are the subject of this study are from Test Unit 5 (see Figure 3.4). One sherd (\#51) is from $30-40 \mathrm{~cm}$ bs, a second sherd (\#52) is from $40-50 \mathrm{~cm} \mathrm{bs}$, and the other three sherds (\#53-1, \#53-2, and \#53-3) are from 50-60 cm bs. Presumably these sherds are from a single prehistoric archeological component, one apparently associated with the Late Prehistoric Toyah interval (ca. A.D. 1200-1700) (Douglas Boyd, personal communication 2009). Based on differences in temper or apparent temper, firing, and decoration (Table C.1), the five sherds are apparently from four different vessels; sherds \#53-1 and \#53-3 may be from the same vessel.

Sherd \#51 is from an engraved carinated bowl (see Table C.1), a vessel form associated with the manufacture of prehistoric and early historic Caddo ceramics throughout all of East Texas (see Suhm and Jelks 1962). The form of the vessels from which the other four sherds derive is not known-primarily because of the small size of the sherds-but the sherd thickness $(7.4-8.2 \mathrm{~mm}$ ) and the decoration (fingernail punctated) suggest that they are from utility ware vessels, probably cooking jars. The two exterior burnished sherds \#52 and \#53-1 may be from simple bowls.

The engraved sherd has a panel of diagonal engraved lines on the rim of the carinated bowl. This relatively simple geometric design is present on several defined Caddo pottery types, including Holly Fine Engraved, Sanders Engraved, and Spiro Engraved (see Suhm and Jelks 1962), although the engraved lines on Holly Fine Engraved and Spiro Engraved are typically finely executed, while the engraved lines on sherd \#51 are assuredly not finely

Table C.1. Aboriginal ceramic sherds from 41BQ285

\begin{tabular}{|c|c|c|c|c|c|c|}
\hline Sherd No. & Sherd Type & $\begin{array}{l}\text { Surface } \\
\text { Treatment }\end{array}$ & $\begin{array}{l}\text { Visible } \\
\text { Temper }\end{array}$ & $\begin{array}{l}\text { Firing } \\
\text { Conditions }\end{array}$ & $\begin{array}{l}\text { Thickness } \\
(\mathrm{mm})\end{array}$ & Decoration \\
\hline 51 & body, CB & $\mathrm{I} / \mathrm{E} \mathrm{B}$ & grog & $\mathrm{F}^{*}$ & $5.8-7.1$ & $\begin{array}{l}\text { diagonal } \\
\text { engraved }\end{array}$ \\
\hline 52 & body & E B & grog? & $\mathrm{K}$ & 8.2 & plain \\
\hline $53-1$ & body & E B & grog? & $\mathrm{G}$ & 7.7 & plain \\
\hline $53-2$ & body & I SM & $\begin{array}{l}\text { sparse } \\
\text { bone; sandy } \\
\text { paste }\end{array}$ & $\mathrm{K}$ & 7.8 & $\begin{array}{l}\text { single } \\
\text { fingernail } \\
\text { punctated }\end{array}$ \\
\hline $53-3$ & body & I/E SM & grog? & $\mathrm{G}$ & 7.4 & $\begin{array}{l}\text { single } \\
\text { fingernal } \\
\text { punctated }\end{array}$ \\
\hline
\end{tabular}

Notes: $\mathrm{CB}=$ carinated bowl; $\mathrm{I}=$ interior vessel surface $\mathrm{E}=$ exterior vessel surface; $\mathrm{B}=$ burnished; $\mathrm{SM}=$ smoothed

Firing conditions: $\mathrm{F}-\mathrm{G}=$ fired in a reducing environment and cooled in the open air; $\mathrm{K}=$ smothered, sooted, or smudged (see Perttula 2005:Figure 5-30; Teltser 1993:Figure 2). 
executed. Such a geometric design on a carinated bowl form is probably also part of the decorative motifs on a number of typologically undefined Early and Middle Caddo pottery vessels and sherds in East Texas. No typological identification of the 41BQ285 sherds was attempted. The Early and Middle Caddo periods in East Texas date to ca. A.D. 1000-1400 (Story 1990), and a Middle Caddo affiliation for the engraved sherd from 41BQ285 would be consistent with the recovery of both Perdiz points and several of the calibrated radiocarbon dates from the site.

Two body sherds (\#53-2 and \#53-3) have single fingernail punctations (see Table C.1). Given the size of the sherds, the occurrence of only single fingernail punctates suggests that these two vessels must have had widely spaced or freely spaced fingernail punctations on the vessel body.

Four of the five sherds from 41BQ285 are apparently tempered with grog or small amounts of crushed pieces of fired clay (see Table C.1). Whether these pieces represent deliberately added crushed sherd fragments-as is so commonly seen in East Texas Caddo ceramic wares-or incidental inclusions incorporated in the clay paste during its preparation for vessel manufacture has not been determined. The absence of identified grog aplastics in the petrographic analysis of three of these four sherds (see Robinson, below) suggests that the small pieces of apparent fired clay are probably incidental inclusions, and not deliberately added pieces of temper, except in the case of the grogtempered engraved sherd (see Table C.1). One of the fingernail-punctated sherds has sparse burned bone temper. Grog was the preferred temper of choice for Caddo pottery throughout much of East Texas and for all temporal periods, particularly in the upper Neches, Sabine, Big Cypress, and Sulphur River basins. Shelltempered pottery began to be manufactured by Caddo potters after ca. A.D. 1300 in much of the Red River basin in East Texas, while the use of bone as a temper was common around the same time in parts of the Neches and Angelina River basins (see Perttula 2009a:Figure 6-70).

Three of the sherds have been burnished on one or both vessel surfaces, and the other two have smoothed vessel surfaces (see Table C.1). The one carinated bowl sherd has been burnished on both vessel surfaces, and one fingernail-punctated sherd has been smoothed on both vessel surfaces.

Three of the five sherds are from vessels fired in a reducing or low-oxygen environment (probably smothered in a bed of coals from a wood fire). These vessels were subsequently exposed to air or cooled in a high oxygen environment (i.e., fire-hardened vessels were removed from the fire to cool), where one or both vessel surfaces had thin oxidized or light-colored (red to reddish-brown) surface colors. Two sherds have a distinctive core, with a light exterior and core, except for a thin dark band along the interior surface (firing condition K in Table C.1). These vessels with this kind of firing may have been placed in a fire with the "orifice [of the vessel] facing into the fire" (Aten and Bollich 2002:54-55). Furthermore, the sherds with cores lighter than one or both surfaces may have come from vessels where "after extended firing that burned off all organics, the fire may have been smothered to cause reduction and darkening of the exterior surface."

\section{CERAMIC PETROGRAPHIC ANALYSIS OF FIVE POTTERY SHERDS FROM 41BQ285, BOSQUE COUNTY, NORTH CENTRAL TEXAS}

\section{David G. Robinson}

A petrographic analysis of five small pottery sherds from 41BQ285 was completed. The petrographic analysis was conducted to gain insight into the technology of pottery making and to assess the materials' affinities with prehistoric Caddo pottery, commonly found east of the Bosque River basin and the Trinity River. It was thought that potential affinities or identities could be made on two bases. First, minerals, other bodies, and identified Caddo ceramic technology could mark Caddo ceramics in the study collection. Second, mineral components could identify geological areas of origin in the Caddo region of East Texas. By either of these methods, identified connections could be ascertained. The sherds subjected to petrographic analysis also were analyzed by instrumental neutron activation analysis (see Ferguson and Glascock, below). Comparative results of the two methods are presented in the Synthesis of the Findings section at the end of this appendix. 


\section{METHODOLOGY}

\section{Petrographic Thin Section Analysis}

The principal method of the analysis was the identification and point-counting of minerals and ceramic structures following the method of Chayes (1949) and the approach to petrographic analysis pioneered in archeology by Shepard $(1942,1954)$. The thin sections were prepared by National Petrographic Service, Inc., in Houston, Texas. The microscopic analysis was performed on an Olympus stereographic microscope at the microscopy lab of the Texas Archeological Research Laboratory, The University of Texas at Austin.

Point counting is a standard procedure that offers replicable results. It amounts to counting a set number (at least 200 in this case) of ceramic attributes observed in the viewing field during systematic microscopic traverses of each thin section. Counting the same number of ceramic attributes in each thin section allows reliable statistical comparisons. Counted attributes included the ceramic fabric "matrix," pore space, and discrete inclusions such as crushed minerals and sand. Additional information such as grain size and shape was recorded on the counting sheet for potential future reference. The color and isotropy of the ceramic matrix was determined and recorded. Any mineral specimen that was observed in the viewing field but did not fall into the count was recorded during the analysis as "tr" for trace, so as not to lose information on rare but potentially significant bodies that also occur in the paste.

The primary means of analysis was to define paste groups among the studied thin sections from 41BQ285, from the observed and counted ceramic features. Paste groups may or may not relate to similar groupings identified on a typological basis. Once defined, however, they allow wider comparisons with paste groups defined on a petrographic basis.

\section{Mineralogy}

The clays used in the manufacture of the 41BQ285 vessels most likely derived from alluvial deposits and do not appear to have the features and consistency of residual beds. The clay materials form the ceramic matrix of each of the original vessels represented by the five pottery sherds, and all the matrixes were isotropic. This attribute suggests low-temperature earthenware firings typical of aboriginal Texas ceramics.

The dominant particle in the clay in each sherd is quartz (Table C.2), with various attributes distributed across the collection. These quartz forms can be grouped, adapting the classifications put forth by Folk (1980:65-71). The most common quartz form in the collection is volcanic quartz, termed here "fresh quartz" to avoid confusion with local, recent sources of quartz in volcanoes, which are certainly not implied by any of the quartz identified in the 41BQ285 thin section collection. The bodies have a variety of sizes and shapes, few microlites or vacuoles, and simple extinction or slightly undulose extinction. The second identified form in the sherds is composite quartz, which has sources in rocks, the formation of which may distress the crystals or constrain their growth in the rock matrix. The bodies look like multiple crystals with jagged boundaries that may interlock and give the appearance of jigsaw puzzle pieces. Extinction varies within each crystal composite and may be simple or undulose. Eroded quartz, as the name implies, has existed in the weathering environment an extended period of time and gained features of weathering such as surface crusts, bubbly exterior surfaces, as well as many vacuoles and microlites. Extinction is slightly to strongly undulose where it can be determined. Eroded quartz shape ranged from subrounded to angular in keeping with the other quartz forms; this implies the crushing of quartz or its parent rock for addition to the matrix as temper. Eroded quartz bodies were not proportionally more rounded than the other quartz forms, nor were there other rounded quartz forms that would imply long-term stream-rolling or beach sands. Chert is a rock allomorph of quartz, and in thin section it appears as congregated anhedral quartz grains formed out of aqueous solution; the grains are distinct from grains of quartzite, which have a compressed or welded appearance. Quartzite was not found in the 41BQ285 thin sections, but the other forms described were observed in variable amounts throughout the collection, in both paste groups (see Table C.2).

Hematite is the next most common class of mineral body in the collection (see Table C.2), the 


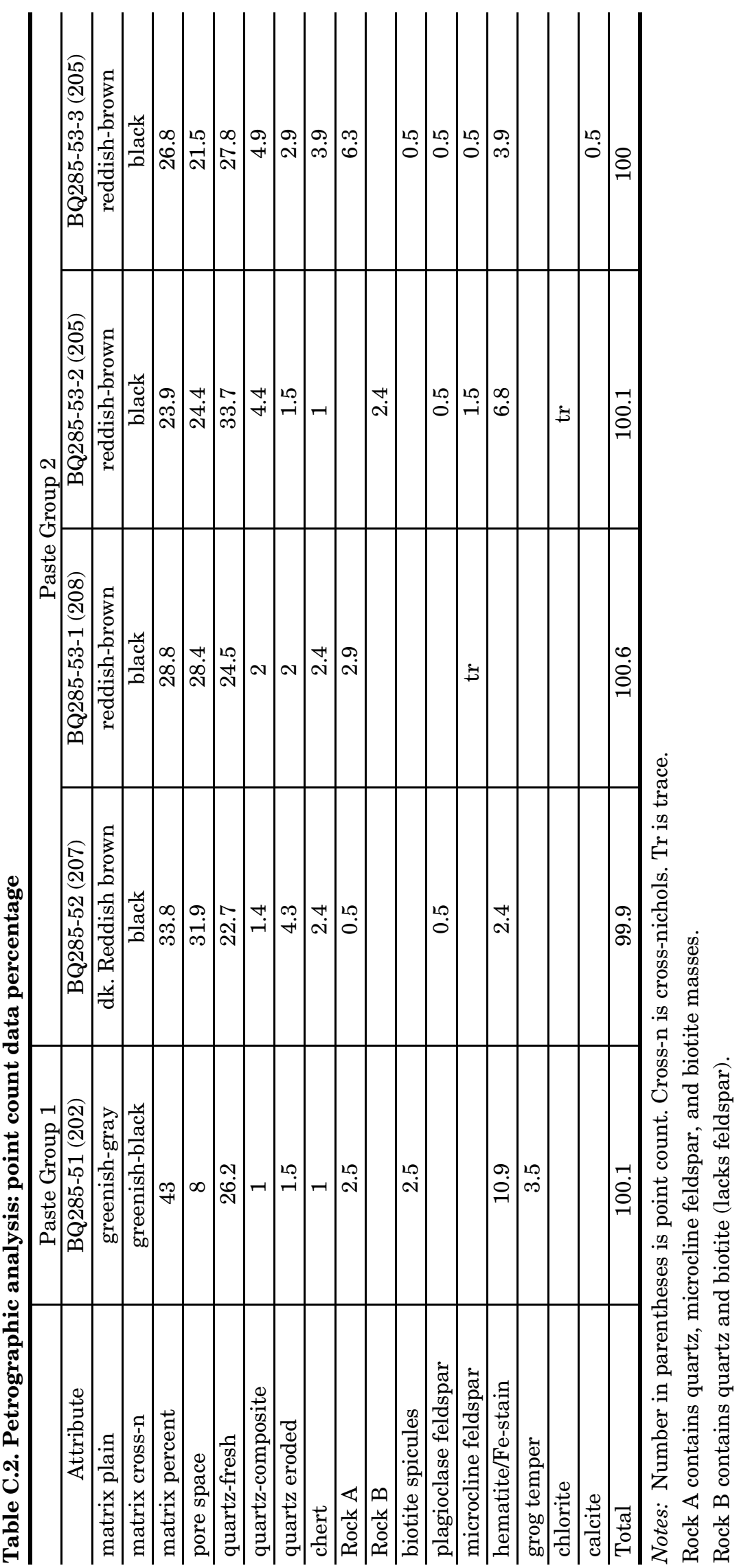


mineral form of iron oxide, where it is present in four of the five sherd thin sections from 41BQ285. Optical tests on the hematite showed it all to be the ferrous form of hematite, which has a valence of ++ . In thin sections, hematite bodies appeared as black, rounded bodies in silt to coarse sand sizes. Occasional bodies showed reddish pigments eroding from the hematite bodies into the clay matrix as though they were a soft material melting in water. These areas were counted as "Fe-stain." Accordingly, hematite was recorded as "hematite/Fe-stain" in Table C.2. Hematite particles are common in geologic formations in Northeast and North Texas, and as Table C.2 indicates, variable amounts were recorded in the two paste groups subsequently defined in the 41BQ285 sherds.

Plagioclase and microcline feldspars were found in minor and trace amounts in four of the five sherds from 41BQ285, all members in Paste Group 2 (see Table C.2). The feldspars did not have an obvious parent source within the collection, and they must be considered detrital residents of the source clays.

Rock type A in the thin section point counts was defined by quartz, microline feldspar, and biotite (see Table C.2). Many rocks have these constituents, and few definitive statements can be made about the rock's petrology. Rock type $\mathrm{B}$ is comprised of several coarse-sized particles in sherd \#53-2 (see Table C.2), which, rather than being consolidated rock, may in fact be unconsolidated clays or sediments. The material contains quartz and biotite in a matrix lighter in color than the surrounding clay matrix. The material comprising Rock type B may be a poorly consolidated sedimentary rock or concretion, or particles of local soil that fell into the ceramic material by accident before firing.

Grog, or sherd, tempering technically is not a mineral body, being comprised of previously fired ceramic material, but it is a significant attribute of the Paste Group 1 sherd (see Table C.2). The grog bodies are rounded to angular, and they range in size from coarse silt to coarse sand in size. They have generally lighter greenish-gray matrixes than the surrounding matrix, and they contain quartz, biotite, and hematite particles. The practice of grog tempering was very common in Caddo ceramic making east of the Trinity River in East Texas, as well as in the Southeastern United States; it was largely unknown elsewhere in Texas aboriginal pottery making.
Chlorite and calcite are trace and minor minerals in two of the Paste Group 2 sherds (see Table C.2). Their small particle sizes suggest that they may have been incidental residents in the ceramic source clays.

\section{FINDINGS AND IMPLICATIONS}

The major ceramic features, minerals, rock fragments, and their proportions identified in the petrographic analysis defined two clear and distinct paste groups in the study collection (see Table C.2). Paste Group 1 was defined only by sherd \#51 (thin section BQ285-51), and Paste Group 2 was composed of the remaining four sherds of the study collection.

\section{Paste Groups \\ Paste Group 1}

Sherd \#51 (BQ285-51)

This 41BQ285 paste group is characterized by a dense, greenish-gray to greenish-black ceramic paste, abundant quartz (29.7 percent), and grog temper. The grog contains the same tempering particles as the surrounding matrix. The paste group has the study collection's highest proportion of hematite, at 10.9 percent, but hematite is present in lower proportions (2.4-6.8 percent) in three of the Paste Group 2 sherds (see Table C.2). Rock A in the paste comprised of quartz, microline feldspar, and biotite spicules; Rock A is also present in three of the Paste Group 2 sherds (see Table C.2). Igneous origins are indicated for the rock, but a specific rock type cannot be determined. Biotite spicules amount to a minor constituent (2.5 percent) of the thin section in medium silt and smaller sizes. They probably have a source in Rock A.

\section{Paste Group 2}

Sherd \#52 (BQ285-52)

Sherd \#53-1 (BQ285-53-1)

Sherd \#53-2 (BQ285-53-2)

Sherd \#53-3 (BQ285-53-3)

Porous, reddish-brown ceramic pastes, abundant quartz particles in various forms (30.8-40.6 percent), and minor amounts of distinctive feldspar define Paste Group 2 in the 
41BQ285 sherds (see Table C.2). Other minor and trace bodies vary widely through the paste group. These include Rock B, chlorite, and calcite in sherds \#53-2 and \#53-3 (see Table C.2). The variety of minor minerals suggests multiple sources of clay for ceramic vessel manufacture or the use of relatively young and poorly sorted alluvial deposits (quartz particle shapes vary from angular to subrounded). This observation supports this finding as well, although some crushing to prepare the quartz material as a tempering agent is likely.

\section{Comparisons}

The sherd of Paste Group 1, sherd \#51, is interpreted from the petrographic analysis to have been part of a Caddo vessel that was probably manufactured outside the Bosque River region. This statement is supported by the grog tempering within the paste, as detected in the thin section, and to a degree by the amount of hematite in the sherd's paste. The density of the paste (based on pore space) in comparison to that of Paste Group 2 is a further indicator of the sherd's extra-regional, and probable East Texas Caddo, origins.

Paste Group 2 is likely one of several regional ceramic pastes used for ceramic vessel manufacture, and it may have derived from local, perhaps onsite, sources. The clay sources were likely immature alluvial deposits. This interpretation is consistent with the site's location on Holocene sediments of an alluvial terrace of the North Bosque River. Some of the sherds of the group may have belonged to the same vessel, based on the petrography conducted here, and if so, it is of interest to observe the fluctuation of the amounts of minor and trace minerals within the same vessel (cf. Perttula et al. 2003:24-25).

Iruegas (in Perttula et al. 2003:23-31) conducted a petrographic analysis of greater scope (27 sherds) than this study, entirely on what were thought to be Caddo sherds from vessels made in East Texas, from sites distributed over five counties in central Texas, north, south, and southeast of the Bosque County study area (Perttula et al. 2003:Table C.4). His paste groups were defined principally on matrix color, followed by the amounts of tempering agents. Applying his standards, Paste Group 1 compares reasonably well to Group 4, on the basis of quartz and grog tempering (Perttula et al. 2003:24-25). The matrix colors of the two groups are disjunctive to an extent, Paste Group 1 being distinctly greenish-gray while Iruegas's Group 4 was described as yellowish-brown. The similarity to note is the generally lighter color of the Group 4 sherd; the differences may be due to viewing the specimens through different optics, or to colorperceptual differences between the analysts. Thus, the comparison fails to produce certainty.

Bioclasts, including bone, shell, foraminifera, and plant particles were common and received thorough consideration in Iruegas's (Perttula at al. 2003:24) study. It is notable that the 41BQ285 sherds contained no organic particles.

Paste Group 2 is distinct from all of Iruegas's paste groups (see Perttula et al. 2003:Tables 4 and 5), furthering the assessment that the 41BQ285 Paste Group 2 sherds identify, and to an extent characterize, the local ceramic materials and techniques employed by the Late Prehistoric occupants of 41BQ285. This paste group exemplifies the Texas hunter-gatherer ceramic tradition of manufacturing low-fired earthenware pottery with material gained from local sources. The plain or simply decorated ceramic vessels produced with this technology are likely to show a diversity of mineral types in their aplastic inclusions, whether they were deliberately or unintentionally added to the paste.

\section{INSTRUMENTAL NEUTRON ACTIVATION ANALYSIS (INAA) OF CERAMIC SAMPLES FROM 41BQ285, BOSQUE COUNTY, TEXAS}

\section{Jeffrey R. Ferguson and Michael D. Glascock}

This section describes the preparation, analysis, and interpretation of five pottery sherd samples from 41BQ285. The limited number of samples from this site prohibits an internal comparison, so the samples are compared to the existing reference groups from central Texas and the Caddo reference groups from East Texas as well as the entire University of Missouri Research Reactor (MURR) ceramic database. Although the groups from central Texas are similar in chemical composition to those in East Texas, there are subtle differences that suggest the samples from 41BQ285 are not Caddo but instead belong to the Central Texas 2 compositional group. 


\section{Sample Preparation}

Pottery samples were prepared for INAA using procedures standard at MURR. Fragments of about $1 \mathrm{~cm}^{2}$ were removed from each sample and abraded using a silicon carbide burr in order to remove glaze, slip, paint, and adhering soil, thereby reducing the risk of measuring contamination. The samples were washed in deionized water and allowed to dry in the laboratory. Once dry, the individual sherds were ground to powder in an agate mortar to homogenize the samples. Archival samples were retained from each sherd (when possible) for future research.

Two analytical samples were prepared from each source specimen. Portions of approximately $150 \mathrm{mg}$ of powder were weighed into clean high-density polyethylene vials used for short irradiations at MURR. At the same time, $200 \mathrm{mg}$ of each sample was weighed into clean high-purity quartz vials used for long irradiations. Individual sample weights were recorded to the nearest $0.01 \mathrm{mg}$ using an analytical balance. Both vials were sealed prior to irradiation. Along with the unknown samples, standards made from National Institute of Standards and Technology (NIST) certified standard reference materials of SRM-1633a (coal fly ash) and SRM688 (basalt rock) were similarly prepared, as were quality control samples (e.g., standards treated as unknowns) of SRM-278 (obsidian rock) and Ohio Red Clay (a standard developed for in-house applications).

\section{Irradiation and Gamma-Ray Spectroscopy}

The neutron activation analysis of ceramics at MURR, which consists of two irradiations and a total of three gamma counts, constitutes a superset of the procedures used at most other INAA laboratories (Glascock 1992; Neff 1992, 2000). As discussed in detail by Glascock (1992), a short irradiation is carried out through the pneumatic tube irradiation system. Samples in the polyvials are sequentially irradiated, two at a time, for five seconds by a neutron flux of $8 \mathrm{x}$ $10^{13} \mathrm{n} \mathrm{cm}^{-2} \mathrm{~s}^{-1}$. The 720 -second count yields gamma spectra containing peaks for nine short-lived elements: aluminum ( $\mathrm{Al})$, barium $(\mathrm{Ba})$, calcium (Ca), dysprosium (Dy), potassium (K), manganese $(\mathrm{Mn})$, sodium $(\mathrm{Na})$, titanium $(\mathrm{Ti})$, and vanadium
(V). The samples are encapsulated in quartz vials and are subjected to 24-hour irradiation at a neutron flux of $5 \times 10^{13} \mathrm{n} \mathrm{cm}^{-2} \mathrm{~s}^{-1}$. This long irradiation is analogous to the single irradiation utilized at most other laboratories. After the long irradiation, samples decay for seven days and then are counted for 1,800 seconds (the "middle count") on a high-resolution germanium detector coupled to an automatic sample changer. The middle count yields determinations of seven medium half-life elements: arsenic (As), lanthanum $(\mathrm{La})$, lutetium $(\mathrm{Lu})$, neodymium $(\mathrm{Nd})$, samarium (Sm), uranium (U), and ytterbium $(\mathrm{Yb})$. After an additional three- or four-week decay, a final count of 8,500 seconds is carried out on each sample. The latter measurement yields the following 17 long half-life elements: cerium (Ce), cobalt (Co), chromium $(\mathrm{Cr})$, cesium $(\mathrm{Cs})$, europium $(\mathrm{Eu})$, iron $(\mathrm{Fe})$, hafnium $(\mathrm{Hf})$, nickel $(\mathrm{Ni})$, rubidium $(\mathrm{Rb})$, antimony $(\mathrm{Sb})$, scandium (Sc), strontium ( $\mathrm{Sr}$ ), tantalum (Ta), terbium $(\mathrm{Tb})$, thorium (Th), zinc (Zn), and zirconium $(\mathrm{Zr})$. The element concentration data from the three measurements are tabulated in parts per million.

\section{Interpreting Chemical Data}

The analyses at MURR, described above, produced elemental concentration values for 33 elements in most of the analyzed samples. Data for $\mathrm{Ni}$ in many samples was below detection limits (as is the norm for most New World ceramics) and was removed from consideration during the statistical analysis. The five samples in this study all had relatively low calcium concentrations; however, many samples from Central and East Texas have higher calcium levels, requiring a calcium adjustment. The analysis here uses calcium-adjusted reference groups. The following mathematical correction was used, as it has been proven to be effective in other calcium-rich data sets (Cogswell et al. 1998:64):

$$
e^{\prime}=\frac{10^{6} e}{10^{6}-2.5 c}
$$

where $e$ ' is the corrected concentration of a given element in ppm, $e$ is the measured concentration of that element in $\mathrm{ppm}$, and $c$ is the concentration of elemental calcium in ppm. After the calcium correction, calcium and strontium were removed from the statistical analyses. 
Statistical analysis was subsequently carried out on base-10 logarithms of concentrations on the remaining 30 elements.

Use of log concentrations rather than raw data compensates for differences in magnitude between the major elements, such as calcium, on one hand, and trace elements, such as the rare earth or lanthanide elements (REEs). Transformation to base-10 logarithms also yields a more normal distribution for many trace elements.

The interpretation of compositional data obtained from the analysis of archaeological materials is discussed in detail elsewhere (e.g., Baxter and Buck 2000; Bieber et al. 1976; Bishop and Neff 1989; Glascock 1992; Harbottle 1976; Neff 2000) and will only be summarized here. The main goal of data analysis is to identify distinct homogeneous groups within the analytical database. Based on the provenance postulate of Weigand et al. (1977), different chemical groups may be assumed to represent geographically restricted sources. For lithic materials such as obsidian, basalt, and cryptocrystalline silicates (e.g., chert, flint, or jasper), raw material samples are frequently collected from known outcrops or secondary deposits, and the compositional data obtained on the samples is used to define the source localities or boundaries. The locations of sources can also be inferred by comparing unknown specimens (i.e., ceramic artifacts) to knowns (i.e., clay samples) or by indirect methods such as the "criterion of abundance" (Bishop et al. 1992) or by arguments based on geological and sedimentological characteristics (e.g., Steponaitis et al. 1996). The ubiquity of ceramic raw materials usually makes it impossible to sample all potential "sources" intensively enough to create groups of knowns to which unknowns can be compared. Lithic sources tend to be more localized and compositionally homogeneous (such as obsidian) or compositionally heterogeneous (such as most cherts).

Compositional groups can be viewed as "centers of mass" in the compositional hyperspace described by the measured elemental data. Groups are characterized by the locations of their centroids and the unique relationships (i.e., correlations) between the elements. Decisions about whether to assign a specimen to a particular compositional group are based on the overall probability that the measured concentrations for the specimen could have been obtained from that group.
Initial hypotheses about source-related subgroups in the compositional data can be derived from noncompositional information (e.g., archaeological context, decorative attributes, etc.) or from application of various pattern-recognition techniques to the multivariate chemical data. Some of the pattern recognition techniques that have been used to investigate archaeological data sets are cluster analysis (CA), principal components analysis (PCA), and discriminant analysis (DA). Each of the techniques has its own advantages and disadvantages, which may depend upon the types and quantity of data available for interpretation.

The variables (measured elements) in archaeological and geological data sets are often correlated and frequently large in number. This makes handling and interpreting patterns within the data difficult. Therefore, it is often useful to transform the original variables into a smaller set of uncorrelated variables in order to make data interpretation easier. Of the abovementioned pattern recognition techniques, $\mathrm{PCA}$ is a technique that transforms the data from the original correlated variables into uncorrelated variables most easily.

PCA creates a new set of reference axes arranged in decreasing order of variance subsumed. The individual PCs are linear combinations of the original variables. The data can be displayed on combinations of the new axes, just as they can be displayed on the original elemental concentration axes. PCA can be used in a pure pattern-recognition mode, i.e., to search for subgroups in an undifferentiated data set, or in a more evaluative mode, i.e., to assess the coherence of hypothetical groups suggested by other criteria. Generally, compositional differences between specimens can be expected to be larger for specimens in different groups than for specimens in the same group, and this implies that groups should be detectable as distinct areas of high point density on plots of the first few components. It is well known that PCA of chemical data is scale dependent (Mardia et al. 1979), and analyses tend to be dominated by those elements or isotopes for which the concentrations are relatively large. This is yet another reason for the log transformation of the data.

One frequently exploited strength of PCA, discussed by Baxter (1992), Baxter and Buck (2000), and Neff $(1994,2002)$, is that it can be applied as a simultaneous R- and Q-mode 
technique, with both variables (elements) and objects (individual analyzed samples) displayed on the same set of principal component reference axes. A plot using the first two principal components as axes is usually the best possible two-dimensional representation of the correlation or variance-covariance structure within the data set. Small angles between the vectors from the origin to variable coordinates indicate strong positive correlation; angles at 90 degrees indicate no correlation; and angles close to 180 degrees indicate strong negative correlation. Likewise, a plot of sample coordinates on these same axes will be the best two-dimensional representation of Euclidean relations among the samples in log-concentration space (if the PCA was based on the variance-covariance matrix) or standardized log-concentration space (if the PCA was based on the correlation matrix). Displaying both objects and variables on the same plot makes it possible to observe the contributions of specific elements to group separation and to the distinctive shapes of the various groups. Such a plot is commonly referred to as a "biplot" in reference to the simultaneous plotting of objects and variables. The variable interrelationships inferred from a biplot can be verified directly by inspecting bivariate elemental concentration plots; note that a bivariate plot of elemental concentrations is not a biplot.

Whether a group can be discriminated easily from other groups can be evaluated visually in two dimensions or statistically in multiple dimensions. A metric known as the Mahalanobis distance (or generalized distance) makes it possible to describe the separation between groups or between individual samples and groups on multiple dimensions. The Mahalanobis distance of a specimen from a group centroid (Bieber et al. 1976; Bishop and Neff 1989) is defined by:

$$
D_{y, X}^{2}=[y-\bar{X}]^{t} I_{x}[y-\bar{X}]
$$

where $y$ is the $1 \mathrm{x} \mathrm{m}$ array of logged elemental concentrations for the specimen of interest, $X$ is the $\mathrm{n} \times \mathrm{m}$ data matrix of logged concentrations for the group to which the point is being compared with $\bar{X}$ being $1 \times \mathrm{m}$ centroid, and $I_{x}$ is the inverse of the $\mathrm{mx} \mathrm{m}$ variance-covariance matrix of group $X$. Mahalanobis distance takes into account variances and covariances in the multivariate group, and it is analogous to expressing distance from a univariate mean in standard deviation units. Like standard deviation units, Mahalanobis distances can be converted into probabilities of group membership for individual specimens. For relatively small sample sizes, it is appropriate to base probabilities on Hotelling's $T^{2}$, which is the multivariate extension of the univariate Student's $t$.

When group sizes are small, Mahalanobis distance-based probabilities can fluctuate dramatically depending upon whether or not each specimen is assumed to be a member of the group to which it is being compared. Harbottle (1976) calls this phenomenon "stretchability" in reference to the tendency of an included specimen to stretch the group in the direction of its own location in elemental concentration space. This problem can be circumvented by crossvalidation, that is, by removing each specimen from its presumed group before calculating its own probability of membership (Baxter 1994; Leese and Main 1994). This is a conservative approach to group evaluation that may sometimes exclude true group members.

Small sample and group sizes place further constraints on the use of Mahalanobis distance: with more elements than samples, the group variance-covariance matrix is singular, thus rendering calculation of $I_{x}$ (and $D^{2}$ itself) impossible. Therefore, the dimensionality of the groups must somehow be reduced. One approach would be to eliminate elements considered irrelevant or redundant. The problem with this approach is that the investigator's preconceptions about which elements should be discriminate may not be valid. It also squanders the main advantage of multi-element analysis, namely the capability to measure a large number of elements. An alternative approach is to calculate Mahalanobis distances with the scores on principal components extracted from the variance-covariance or correlation matrix for the complete data set. This approach entails only the assumption, entirely reasonable in light of the above discussion of PCA, that most groupseparating differences should be visible on the first several PCs. Unless a data set is extremely complex, containing numerous distinct groups, using enough components to subsume at least 90 percent of the total variance in the data can be generally assumed to yield Mahalanobis distances that approximate Mahalanobis distances in full elemental concentration space. 
Lastly, Mahalanobis distance calculations are also quite useful for handling missing data (Sayre 1975). When many specimens are analyzed for a large number of elements, it is almost certain that a few element concentrations will be missed for some of the specimens. This occurs most frequently when the concentration of an element is near the detection limit. Rather than eliminate the specimen or the element from consideration, it is possible to substitute a missing value by replacing it with a value that minimizes the Mahalanobis distance for the specimen from the group centroid. Thus, those few specimens which are missing a single concentration value can still be used in group calculations.

\section{Results}

The following description of the samples refers to the IDs assigned prior to arrival at MURR. Due to the limitations of the analytical software used at MURR, we have relabeled some of the samples during the sample analysis. Table C.3 links the IDs used in this report with those on file in the MURR master database. The analyzed sherds are illustrated in Figure 3.4.

Table C.3. Sample IDs used by MURR

\begin{tabular}{c|c}
\hline MURR ID & Report ID \\
\hline PAI051 & Sherd 51 \\
\hline PAI052 & Sherd 52 \\
\hline PAI053 & Sherd 53-1 \\
\hline PAI054 & Sherd 53-2 \\
\hline PAI055 & Sherd 53-3 \\
\hline
\end{tabular}

\section{Comparison with MURR Database}

The samples from 41BQ285 were projected against the entire MURR ceramic INAA database containing over 55,000 samples, producing surprisingly few close matches. A Euclidian distance of less than 0.012 is generally considered worthy of further investigation. Only one sample has a single match under this value. Sherd \#51 is closely related to sample UT015. UT015 is a sample from Bosque County, Texas, submitted by Darrell Creel (see Neff and Glascock 2002, 2005). This sample was assigned to the
Central Texas (CT) 2 Compositional Group, a group that is very closely related to what was called the Titus group identified from Caddo samples from eastern Texas (Neff and Glascock 2002). This CT2 and Titus overlap is discussed further below.

\section{Comparison with Caddo and Central Texas Compositional Groups}

The MURR Caddo database (consisting of approximately 1000 ceramic samples, mostly submitted by Timothy K. Perttula) is one of the largest samples from any region in the world. It is also one of the most complex. Over the past decade, the compositional group structure has undergone numerous modifications, and it is currently in the process of a complete reanalysis (Ferguson et al. 2008). The most recent interpretation of the East Texas Caddo database divided the region into 11 subregions. Each of these subregions was then treated as an individual data set, and for most subregions, a core group has been isolated. Unfortunately, many of these core groups from different subregions consistently overlap, making the determination of the location of production very problematic. The sherd samples from 41BQ285 were compared to each of the East Texas subregional groups, and the only reasonable match is that sample sherd \#51 overlaps with the Subregion 3 core group. This is a very tenuous assignment since the Subregion 3 core group only has seven members from three Caddo sites in the lower Sulphur River basin in northeastern Texas. Overall, the sherd samples from 41BQ285 generally have rare earth element concentrations too low for assignment to any of the Caddo subregional groups.

The link to the Central Texas Group 2 (CT2) is much more secure, although the analytical utility of this chemical group is in question. All five of the samples from 41BQ285 consistently plot within the ellipses for CT2, and they are different in at least a few elemental concentrations from all five of the remaining Central Texas groups as defined by Neff and Glascock (2002, 2005). Figure C. 1 shows a plot of the new samples and the CT2 group, and Table C.4 lists the probability of membership in the two largest CT groups for each of the new samples.

Neff and Glascock $(2002,2005)$ note that CT Groups 1 and 2 are analogous to the previously 


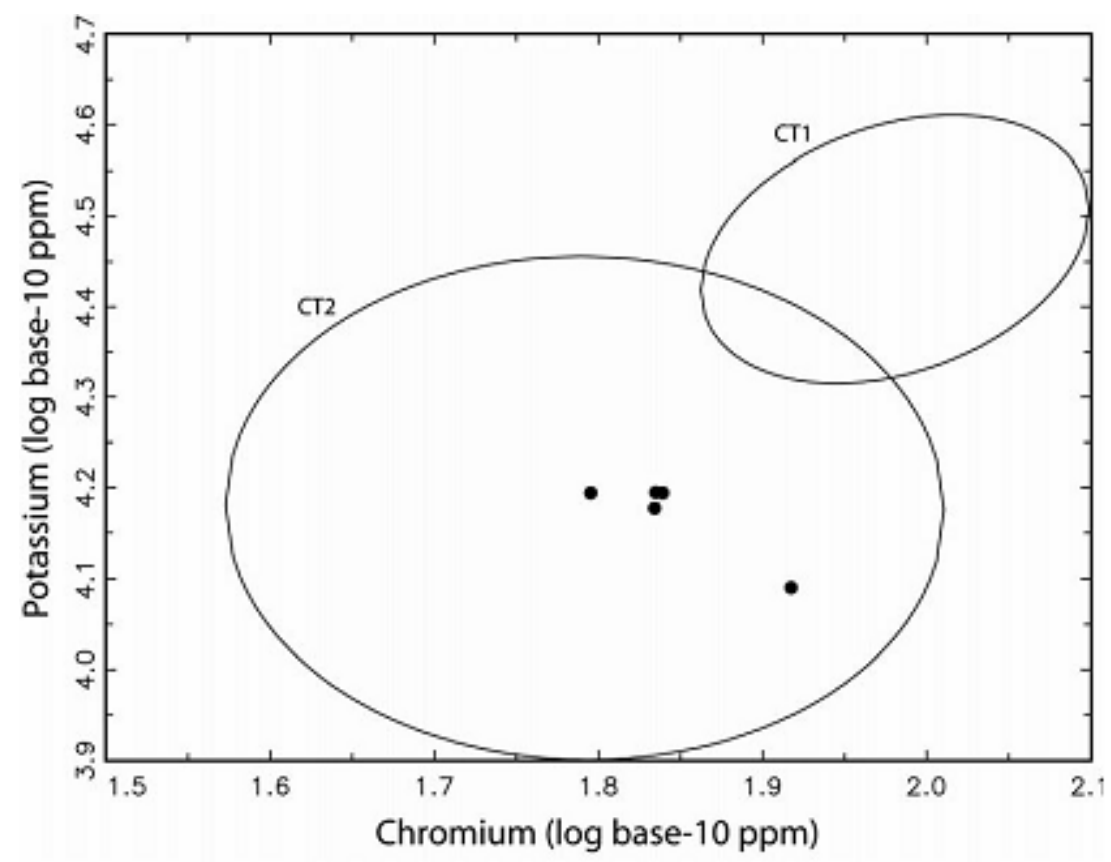

Figure C.1. Bivariate plot of chromium and potassium (log base-10 ppm) showing the relationship between the main CT reference groups and the new samples. The new samples are individually plotted. Ellipses represent 90 percent confidence intervals for membership in the groups.

Table C.4. Probabilities of group membership using a Mahalanobis distance calculation with all elements.

Reference groups and numbers of specimens:

$1 \quad$ CT1 77

$2 \quad$ CT2 178

Variables used:

$\begin{array}{lclllll}\text { AS } & \text { LA } & \text { LU } & \text { ND } & \text { SM } & \text { U } & \text { YB } \\ \text { CE } & \text { CO } & \text { CR } & \text { CS } & \text { EU } & \text { FE } & \text { HF } \\ \text { RB } & \text { SB } & \text { SC } & \text { TA } & \text { TB } & \text { TH } & \text { ZN } \\ \text { ZR } & \text { AL } & \text { BA } & \text { DY } & \text { K } & \text { MN } & \text { NA } \\ \text { TI } & \text { V } & & & & & \end{array}$

Probabilities:

$\begin{array}{lll}\text { ID. } & \text { NO.CT1 } & \text { CT2 } \\ 51 & 0.005 & 70.283 \\ 52 & 0.324 & 57.917 \\ 53-1 & 0.000 & 36.443 \\ 53-2 & 0.012 & 45.057 \\ 53-3 & 0.058 & 12.474\end{array}$


defined East Texas Caddo chemical groups, developed by Neff, referred to as the Red River and Titus chemical groups, respectively. They note that the CT2 samples may be made from clays that experienced greater weathering as a result of increased rainfall closer to the Gulf Coast. Except for the CT2 group, all of the other CT chemical groups seem distinct and exhibit reasonable internal consistency. The $\mathrm{CT} 2$ group is probably too inclusive, much like the Titus group from the Caddo region. Ferguson et al. (2008) attempted the subregional division of the East Texas Caddo INAA database to address this issue. Unfortunately, it has resulted in only limited success. However, the same approach may be more profitable with the Central Texas database. Such a large-scale reanalysis is beyond the scope of this current project, but future central Texas projects may benefit from a reanalysis of the entire INAA database on a subregional scale.

\section{Summary}

The general similarity of the clay parent materials across eastern (Caddo) and central Texas has made the possibility of linking central Texas sherd samples to Caddo production locales difficult at present. However, there is a slightly stronger link between the 41BQ285 sherd samples and the CT2 reference group than with any of the East Texas Caddo chemical groups.

\section{SYNTHESIS OF THE FINDINGS}

Technological, stylistic, petrographic, and instrumental neutron activation analysis (INAA) have all been employed to characterize the nature of the prehistoric ceramic sherds from 41BQ285, but also to ascertain (within reasonable limits) the source and production locales of the five sherds from the Late Prehistoric occupation at the site. The findings of these various approaches are not completely consistent with each other, and this synthesis of the findings reviews the interpretive possibilities arising from the detailed analysis of the 41BQ285 sherds.

The findings of the petrographic analysis and the INAA of four of the sherds (sherds \#52, \#53-1, \#53-2, and \#53-3) from 41BQ285 are in agreement that they are from sherds manufactured from central Texas clays (Paste Group 2 and CT 2 chemical group), perhaps alluvial clays available in the immediate vicinity of the site. The stylistic and technological analyses of these four sherds are more ambiguous, primarily because of the fact that two of the sherds are undecorated, and two have simple fingernailpunctated designs; there may be incidental fired clay pieces in the pastes (see Table C.1). These sherds appear to be from cooking jars, a common vessel form among most prehistoric ceramic traditions in Texas, and otherwise they possess no particular technological or stylistic characteristics that would suggest an East Texas Caddo origin. Thus, it seems reasonable to conclude on the basis of all the analyses that four of the sherds from 41BQ285 represent sherds from a local prehistoric central Texas ceramic tradition.

Sherd \#51 from 41BQ285 is from a grogtempered carinated bowl decorated with diagonal engraved lines. On stylistic and technological grounds, as well as based on the vessel form, a form apparently specific to Caddo ceramic traditions in Texas, this particular sherd may reasonably be concluded to be from a Caddo vessel made in East Texas. The petrographic analysis also concludes that this sherd, of Paste Group 1, is from a Caddo vessel made in East Texas. The evidence to support this petrographic analysis conclusion is the use of grog temper added to the paste, the amount of hematite in the paste, as well as the density (pore space) of the paste in comparison to the Paste Group 2 sherds. The INAA, however, of sherd \#51, makes the alternative case that this sherd belongs to the CT 2 chemical group (in fact, the probability of membership of sherd \#51 in the CT 2 chemical group is higher than the other four sherds from 41BQ285, see Table C.4). Furthermore, no conclusive linkages could be made from the INAA results of sherd \#51 with existing East Texas Caddo chemical groups. What is the most reasonable conclusion, then, concerning the cultural affiliation and production locale of the one engraved and grog-tempered sherd from 41BQ285?

First, while not found in great numbers, engraved sherds from vessels of apparent Caddo origin have been found at a number of sites in central Texas (see Jelks 1962; Perttula et al. 2003; Ricklis and Collins 1994; Shafer 2006; Sorrow et al. 1967; Stephenson 1970; Turner 1997; Watt 1953), particularly sites "restricted to the eastern margin of the Edwards Plateau and the prairie environment immediately to 
the east and northeast of the plateau" (Ricklis and Collins 1994:305 and Figure 155). These engraved wares are from contexts that in East Texas Caddo sites would date from Early Caddo (ca. A.D. 900-1200) to Historic Caddo (ca. A.D. 1680-1800) times, but with an apparent peak in Caddo style engraved pottery in central Texas prairie sites dating before ca. A.D. 1300 (cf. Shafer 2006). The engraved sherd from 41BQ285 appears to be associated with an occupation that would date no earlier than the late thirteenth century A.D., and might well date after the fifteenth century A.D.

Second, it seems a distinct possibility that Caddo vessels manufactured in a number of different regions in East Texas (see Perttula et al. 2003:Figure 16) were only very occasionally traded or exchanged for various reasons with aboriginal hunter-gatherer groups whose territorial range included the Central Brazos river basin. That these same hunter-gatherer groups did make their own pottery, albeit in low amounts, is indicated by the recovery of locally produced plain and fingernail-punctated sherds at 41BQ285 from Paste Group 2, as well as bonetempered plain and bone-tempered brushedpunctated utility wares (Boothe Brushed) from a number of sites across the region. Accordingly, on the basis of a stylistic, petrographic, and chemical analysis of sherds from 11 other central Texas sites (Perttula et al. 2003:Figure 1), Perttula et al. (2003:63) concluded that:

The generally low number of Caddoan [sic] pottery sherds found on many central Texas sites, and the fact that the pottery was not made from central Texas clays, indicates that the sherds are from vessels traded to local central Texas hunter-gatherers, not vessels produced by Caddoan [sic] peoples who had settled in or were periodically using the central Texas region.

Under this scenario, engraved vessel sherds from central Texas aboriginal sites, including the one sherd from 41BQ285, are likely to be from vessels made by Caddo potters living in East Texas. Where within this Caddo region the vessel represented by the one engraved sherd at 41BQ285 was made is not known because the stylistic character of the engraved sherd is not regionally distinctive. The fact that the engraved sherd is from a grog-tempered vessel also does not help narrow down the region of vessel production because such Caddo potterywhether from plain or decorated vessels-is present throughout East Texas in Caddo times.

Alternatively, Shafer (2006:5) has strongly suggested that "[a]rguable prehistoric Caddoan groups occupied the central Brazos valley and its tributaries by A.D. 1100 if not earlier, based on crossdating artifact styles from the George C. Davis site....Terminal dates are ca. A.D. 1250-1300, based on crossdating and extant dates" from prehistoric sites in central Texas. Shafer considers these groups the Prairie Caddo. He goes on to hypothesize that the southern Prairie Caddo (i.e., the central Brazos and its tributaries, such as the North Bosque river) permanently occupied "portions of the central Brazos valley with intermittent and interdigitated Caddo presence in the peripheries to the west and south" (Shafer 2006:7). Site 41BQ285 is located in one of these proposed peripheral areas to the west of the Brazos River, and may be considered by some to be a southern Prairie Caddo site. Shafer (2006:10) has also argued that Caddo ceramics made at the George C. Davis site in the middle Neches River valley in East Texas were moving or being exported to outlying settlements in the southern Prairie Caddo area. This pottery was thought to have been obtained during feasting activities at the George C. Davis site, and then apparently carried back to central Texas and used "essentially for domestic roles" (Shafer 2006:26). He also suggests that "the absence of fine engraved pottery would be expected in small hunting camps," while larger villages on the Brazos and various tributaries would have a "variety of vessels in both form and decoration" (Shafer 2006:10).

It is not known if 41BQ285 is considered a hunting camp, but Griffith and Kibler (2007) suggest the site was used for only a limited number of activities and that a wide range of local faunas were exploited by its occupants. These occupants used, broke, and discarded at least one engraved vessel at the site, but during a time period likely after the George C. Davis site was abandoned (ca. early A.D. 1300s). Neither the petrographic analysis nor the INAA results suggest, however, that the $41 \mathrm{BQ} 285$ vessel was made in the middle Neches River valley, leaving little possibility that its production locale was the George C. Davis Caddo community. This does not mean, however, that a southern Prairie 
Caddo potter living in the central Brazos River basin did not make the engraved vessel that was subsequently discarded at 41BQ285.

A fourth and final possibility is that the engraved sherd from 41BQ285 was from a vessel made from central Texas clays, either by central Texas hunter-gatherers, southern Prairie Caddo, or by an East Texas Caddo group on a foray in the Bosque River basin. The INAA results support the notion that the engraved carinated bowl was made from central Texas clays (see Table C.1), as do certain aspects of the petrographic findings. In particular, while grog tempering and hematite are present in the paste of sherd \#51-common constituents in East Texas Caddo pottery (Perttula 1999:Table 9-14), particularly grog temper, but less so hematite inclusions-there are a number of examples in other central Texas ceramic assemblages of demonstrably locally produced ceramic wares (i.e., Toyah phase wares, in the main) also containing both inclusions (see Black 1986; Green and Hester 1973; Highley 1986; Perttula 2009b, 2009c; Quigg and Peck 2005; Reese-Taylor 1995; Skelton 1977; Treece et al. 1993; Trierweiler 1996). The "grog" is typically described as fired clay lumps.

In the specific case of hematite, its occurrence in the paste of Caddo sherds, as detected in several petrographic analyses from East Texas Caddo sites in the Sabine, Sulphur, and Big Cypress stream basins, ranges from only 0.6 to 7.7 percent of the point counts, with a mean percentage of only 3.3 percent (Perttula 1999:Table 9-14). As rather convincingly shown by petrographic analysis and INAA, three of the four sherds from 41BQ285, including the engraved sherd (\#51) and two (\#53-2 and \#53-3) of the four other sherds, are considered to have come from central Texas manufactured vessels, based on higher hematite point count percentages (see Table C.2). The presence and proportion of hematite may not be a particularly robust measure of ceramic provenance or production locales.

What is intriguing about the engraved sherd from 41BQ285 is that it contains rock particles of igneous origin (Rock A in Table C.2). Three of the sherds in Paste Group 2-considered to represent sherds from vessels made with central Texas clays-also have the same igneous rock particles in their paste. It is not to be expected that East Texas clays would contain igneous particles, as the geological formations in the region are the product of deposition of coastal parent materials, while parent materials in various parts of central Texas are derived from igneous formations.

All things being equal, it is a curious finding that igneous rock particles are an inclusion in the engraved sherd (\#51) from 41BQ285. That finding, along with the fact that the same igneous rocks are found in most of the other sherds from the site that are considered to be from vessels made from central Texas clays (Paste Group 2), when coupled with the INAA findings of a high probability of membership in the CT 2 chemical group, lends weight ultimately to the conclusion that this engraved sherd was from a vessel made from a central Texas clay source. What prehistoric aboriginal group made this sherd remains to be determined.

\section{ACKNOWLEDGMENTS}

We appreciate the opportunity provided by Doug Boyd of Prewitt and Associates, Inc., to conduct these analyses of the sherds from 41BQ285. Ferguson and Glascock acknowledge Mandy Watkins and Corinne Rosania for their role in preparing the INAA samples for irradiation. 


\section{REFERENCES CITED}

Aten, L. E., and C. N. Bollich

2002 Late Holocene Settlement in the Taylor Bayou Drainage Basin: Test Excavations at the Gaulding Site (41JF27), Jefferson County, Texas. Studies in Archeology 40, Texas Archeological Research Laboratory, The University of Texas at Austin, and Special Publication No. 4, Texas Archeological Society.

Baxter, M. J.

1992 Archaeological Uses of the Biplot-A Neglected Technique? In Computer Applications and Quantitative Methods in Archaeology, 1991, edited by G. Lock and J. Moffett, pp. 141-148. BAR International Series S577. Tempvs Reparatvm, Archaeological and Historical Associates, Oxford.

1994 Exploratory Multivariate Analysis in Archaeology. Edinburgh University Press, Edinburgh.

Baxter, M. J., and C. E. Buck

2000 Data Handling and Statistical Analysis. In Modern Analytical Methods in Art and Archaeology, edited by E. Ciliberto and G. Spoto, pp. 681-746. John Wiley and Sons, Inc., New York.

Bieber, A. M. Jr., D. W. Brooks, G. Harbottle, and E. V. Sayre

1976 Application of Multivariate Techniques to Analytical Data on Aegean Ceramics. Archaeometry 18:59-74.

Bishop, R. L., and H. Neff

1989 Compositional Data Analysis in Archaeology. In Archaeological Chemistry IV, edited by R. O. Allen, pp. 576-586. Advances in Chemistry Series 220. American Chemical Society, Washington, D.C.

Bishop, R. L., R. L. Rands, and G. R. Holley 1992 Ceramic Compositional Analysis in Archaeological Perspective. In Advances in Archaeological Method and Theory, vol. 5, edited by M. B. Schiffer, pp. 275-330. Academic Press, New York.

Black, S. L.

1986 Prehistoric Ceramics. In The Prehistoric Sites at Choke Canyon Reservoir, Southern Texas: Results of Phase II Archaeological Investigations, by G. D. Hall, T. R. Hester, and S. L. Black, pp. 337-391. Choke Canyon Series, Volume 10. Center for Archaeological Research, The University of Texas at San Antonio.

Chayes, F.

1949 A Simple Point-Counter for Thin Section Analysis. American Mineralogist 34:1-11.

Cogswell, J. W., H. Neff, and M. D. Glascock

1998 Analysis of Shell-Tempered Pottery Replicates: Implications for Provenance Studies. American Antiquity 63:63-72.

Ferguson, J. R., T. K. Perttula, and M. D. Glascock 2008 Dividing Up the Caddo Cultural Landscape: Small-Scale Analysis of a Large Ceramic INAA Database. Poster presented at the $73^{\text {rd }}$ annual meeting of the Society for American Archaeology. Vancouver, British Columbia.

Folk, R. L.

1980 Petrology of Sedimentary Rocks. Hemphill Publishing Company, Austin.

Glascock, M. D.

1992 Characterization of archaeological ceramics at MURR by neutron activation analysis and multivariate statistics. In Chemical Characterization of Ceramic Pastes in Archaeology, edited by H. Neff, pp. 11-26. Prehistory Press, Madison, Wisconsin.

Green, L. M., and T. R. Hester

1973 The Finis Frost Site: a Toyah Phase Occupation in San Saba County, Central Texas. Bulletin of the Texas Archeological Society 44:69-88.

Griffith, T. B., and K. W. Kibler

2007 National Register Testing at 41BQ285, Bosque County, Texas: FM 56 Bridge Replacement at the North Bosque River. Manuscript on file, Prewitt and Associates, Inc., Austin.

Harbottle, G.

1976 Activation Analysis in Archaeology. Radiochemistry 3:33-72. The Chemical Society, London.

Highley, C. L.

1986 Archaeological Investigations at 41LK201, Choke Canyon Reservoir, Southern Texas. Choke Canyon Series, Volume 11. Center for Archaeological Research, The University of Texas at San Antonio. 
Jelks, E. B.

1962 The Kyle Site: A Stratified Central Texas Aspect Site in Hill County, Texas. Archaeology Series, No. 5. Department of Anthropology, The University of Texas at Austin.

Leese, M. N., and P. L. Main

1994 The Efficient Computation of Unbiased Mahalanobis Distances and Their Interpretation in Archaeometry. Archaeometry 36:307-316.

Mardia, K. V., J. T. Kent, and J. M. Bibby

1979 Multivariate Analysis. Academic Press, London.

Neff, H.

1992 Introduction. In Chemical Characterization of Ceramic Pastes in Archaeology, edited by H. Neff, pp. 1-10. Prehistory Press, Madison, Wisconsin.

1994 RQ-Mode Principal Components Analysis of Ceramic Compositional Data. Archaeometry 36:115-130.

2000 Neutron Activation Analysis for Provenance Determination in Archaeology. In Modern Analytical Methods in Art and Archaeology, edited by E. Ciliberto and G. Spoto, pp. 81-134. John Wiley and Sons, Inc., New York.

2002 Quantitative Techniques for Analyzing Ceramic Compositional Data. In Ceramic Source Determination in the Greater Southwest, edited by D. M. Glowacki and H. Neff, pp. 15-36. Monograph 44. Cotsen Institute of Archaeology, University of California at Los Angeles.

Neff, H., and M. D. Glascock

2002 Compositional Variation in Aboriginal Ceramics from Central Texas: Results of Instrumental Neutron Activation Analysis. Report on file at Archaeometry Laboratory, Research Reactor Center, University of Missouri, Columbia.

2005 Compositional Variation in Aboriginal Ceramics from Central Texas: Results of Instrumental Neutron Activation Analysis. In Analysis and Reporting for 41FY135, the Sandbur Site, Fayette County, Texas, by A. J. Kalter, R. M. Rogers, and M. N. Smith, pp. C-5 to C-35. Report No. 73. Archeological Studies Program, Texas Department of Transportation, Austin.
Neff, H., R. L. Bishop, and E. V. Sayre

1988 A Simulation Approach to the Problem of Tempering in Compositional Studies of Archaeological Ceramics. Journal of Archaeological Science 15:159-172.

Perttula, T. K.

2009a The Ceramic Artifacts from the Lang Pasture Site (41AN38) and the Place of the Site Within an Upper Neches River Basin Caddo Ceramic Tradition. In Archeological Investigations at the Lang Pasture Site (41AN38) in the Upper Neches River Basin of East Texas, edited by T. K. Perttula and D. B. Kelley. Manuscript on file, Texas Department of Transportation, Archeological Studies Program, and prepared by Archeological \& Environmental Consultants, LLC, Austin, and Coastal Environments, Inc., Baton Rouge.

2009b Bone-Tempered Plain Ware Ceramic Sherds from 41BX254, 41BX256, and 41BX1628 along the San Antonio River, Bexar County, Texas. Report submitted to Ecological Communications Corporation, Austin.

2009c Analysis of the Aboriginal Ceramic Sherds from the Bowmer Site (41BL116) and the Bowmer 3 Site (41BL110), Bell County, Texas. Manuscript on file, Archeological \& Environmental Consultants, LLC, Austin.

Perttula, T. K. (editor)

1999 The Hurricane Hill Site (41HP106): The Archaeology of a Late Archaic/Woodland and early-Middle Caddoan Settlement in Northeast Texas. 2 Vols. Special Publication No. 4. Friends of Northeast Texas Archaeology, Austin and Pittsburg.

2005 Archeological Investigations at the Pilgrim's Pride Site (41CP304), a Titus Phase Community in the Big Cypress Creek Basin. 2 Vols. Report of Investigations No. 30. Archeological \& Environmental Consultants, LLC, Austin.

Perttula, T. K., S. A. Iruegas, and H. Neff

2003 Caddoan Pottery in Central Texas: Geochemical Analyses of Ceramics from Fort Hood and Vicinity. Research Report No. 51, Archeological Resource Management Series. United States Army Fort Hood, Fort Hood, Texas.

Quigg, J. M., and J. Peck

2005 The Rush Site (41TG346): A Stratified Late Prehistoric Locale in Tom Green County, 
Texas. Technical Report No. 816C. Mariah Associates, Inc., Austin.

Reese-Taylor, K.

1995 Petrographic Analysis of Ceramic Thin Sections. In NRHP Significance Testing of 57 Prehistoric Archeological Sites on Fort Hood, Texas, edited by J. T. Abbott and W. N. Trierweiler, pp. E-1 to E-11. Research Report No. 34. Archeological Resource Management Series, United States Army Fort Hood.

Ricklis, R. A., and M. B. Collins

1994 Archaic and Late Prehistoric Human Ecology in the Middle Onion Creek Valley, Hays County, Texas. 2 Vols. Studies in Archeology 19. Texas Archeological Research Laboratory, The University of Texas at Austin.

Sayre, E. V.

1975 Brookhaven Procedures for Statistical Analyses of Multivariate Archaeometric Data. Brookhaven National Laboratory Report BNL-23128. New York.

Shafer, H. J.

2006 People of the Prairie:A Possible Connection to the Davis Site Caddo. Archeological Studies Program, Environmental Affairs Division, Texas Department of Transportation, and Prewitt and Associates, Inc., Austin.

Shepard, A. O.

1942 Rio Grande Glaze Paint Ware: A Study Illustrating the Place of Ceramic Technological Analysis in Archaeological Research. Contributions to American Anthropology and History 7(39). Carnegie Institution of Washington, Washington, D.C.

1954 Ceramics for the Archaeologist. Publication 609. Carnegie Institution of Washington, Washington, D.C.

Skelton, D. W.

1977 Archeological Investigations at the Fayette Power project, Fayette County, Texas. Research Report No. 60. Texas Archeological Survey, The University of Texas at Austin.

Sorrow, W. M., H. J. Shafer, and R. E. Ross

1967 Excavations at Stillhouse Hollow Reservoir. Papers of the Texas Archeological Salvage project No. 11. Texas Archeological Salvage project, The University of Texas at Austin.
Stephenson, R. L.

1970 Archeological Investigations in the Whitney Reservoir Area, Central Texas. Bulletin of the Texas Archeological Society 41:37-277.

Steponaitis, V., M. J. Blackman, and H. Neff

1996 Large-Scale Compositional Patterns in the Chemical Composition of Mississippian Pottery. American Antiquity 61:555-572.

Story, D. A.

1990 Cultural History of the Native Americans. In The Archeology and Bioarcheology of the Gulf Coastal Plain, by D. A. Story, J. A. Guy, B. A. Burnett, M. D. Freeman, J. C. Rose, D. G. Steele, B. W. Olive, and K. J. Reinhard, pp. 163-366. 2 Vols. Research Series No. 38. Arkansas Archeological Survey, Fayetteville.

Suhm, D. A., and E. B. Jelks (editors)

1962 Handbook of Texas Archeology: Type Descriptions. Initial Series of Descriptions. Special Publication No. 1, Texas Archeological Society, and Bulletin No. 4, Texas Memorial Museum, Austin.

Teltser, P. A.

1993 An Analytic Strategy for Studying Assemblage-Scale Ceramic Variation: A Case Study from Southeast Missouri. American Antiquity 58(3):530-543.

Treece, A. C., C. Lintz, W. N. Trierweiler, J. M. Quigg, and K. A. Miller

1993 Cultural Resource Investigations In The O. H. Ivie Reservoir, Concho, Coleman, and Runnels Counties, Texas, Volume IV: Data Recovery Results from Ceramic Sites. Technical Report 346-IV. Mariah Associates, Austin.

Trierweiler, W. N. (editor)

1996 Archeological Testing of 56 Prehistoric Sites at Fort Hood, 1994-1995. Archeological Resource Management Series, Research Report No. 35. United States Army, Fort Hood.

Turner, R. L., Jr.

1997 Analysis of the Asa Warner (41ML46) Ceramics. Bulletin of the Texas Archeological Society 68:231-239.

Watt, F. H.

1953 Pottery Diffusions of the Central Brazos Valley. Central Texas Archeologist 6:57-85. 
Weigand, P. C., G. Harbottle, and E. V. Sayre

1977 Turquoise Sources and Source Analysis: Mesoamerica and the Southwestern U.S.A. In Exchange Systems in Prehistory, edited by T. K. Earle and J. E. Ericson, pp. 15-34. Academic Press, New York. 
APPENDIX D: Analysis of Freshwater Mussel Shells

Karen M. Gardner 



\section{METHODOLOGY}

Freshwater mussels from 41BQ285 were analyzed to provide information on the range and variety of species found at the site. Only intact valves and umbo fragments were analyzed, since body fragments are not typically suitable for identification and do not contribute to an accurate assessment of the assemblage.

The shells selected for analysis were identified using comparative literature, mussel identification guides, and the Prewitt and Associates, Inc., comparative collection. Each shell was identified to the genus and species level, unless the condition or fragmentary nature of the shell made confident identification of the species questionable. A shell was considered unidentifiable when the fragment was too small, too fragmentary, or too poorly preserved for a definite identification. It is important to note that since valves were not identified to side, i.e., left or right, all counts indicate the number of individual valves rather than a representation of the number of individual animals present. Each shell was also examined for any evidence of intentional modification or for indicators of heating or burning.

\section{SPECIES DESCRIPTIONS}

The majority of the shell analyzed was identified to at least the species level, with a small percentage identified only to the genus level and a smaller percentage unidentifiable.

As shown in Table D.1, all of the mussel shells analyzed are freshwater mussels belonging to the family Unionidae. Information specific to each genus and species is provided, including common name, range of occurrence, and preferred habitats.

Amblema plicata (Threeridge) is a common Texas species found throughout central and east Texas. It ranges from the San Antonio and Guadalupe Rivers into other drainage basins to the north and east (Howells et al. 1996:34). This species is adaptable, having been documented in a variety of locations, from small streams to large rivers, as well as in lakes and reservoirs. Usually found at water depths of one to three feet, it favors a variety of substrates including mud, sand, clay, gravel, or combinations of these (Cummings and Mayer 1992:40; Howells et al. 1996:34; Parmalee and Bogan 1998:63).
Cyrtonaias tampicoensis (Tampico Pearlymussel) has been documented in Texas in parts of the Trinity River system as well as the Rio Grande, Nueces, Frio, San Antonio, Guadalupe, and Brazos River systems (Howell et al. 1996:48). An adaptable species, it has been found in a range of locations, from slow river to swifter-moving streams, as well as in some reservoirs. This species favors substrates that are made up of a combination of mud, sand, and gravel, although it has occasionally been found on cobble or rock surfaces. It is rarely found on substrates comprised of deep silt or shifting sands (Howells et al. 1996:49).

Lampsilis hydiana (Louisiana Fatmucket) is found from the San Antonio River into drainage systems to the north and east. It has also been documented in the Nueces River system (Howell et al. 1996:65). This species is found in rivers, streams, and reservoirs, typically with quiet or slow-moving waters. This species favors a mud bottom, but also has been found on other surfaces such as mud and sand substrates (Cummings and Mayer 1992:150; Howells et al. 1996:66; Parmalee and Bogan 1998:134).

Lampsilis teres (Yellow Sandshell) is another common Texas species, found in all of the major river systems. It is an adaptable mussel, having been documented at depths ranging from 12 to 15 feet, and in large and small streams and rivers and in slow- to fast-moving currents. It is found on many different substrates, from mud to rocks, although it appears to avoid deep and shifting sand substrates (Howells et al. 1996:69-70; Parmalee and Bogan 1998:138).

Leptodea fragilis (Fragile Papershell) is found ranging from the Colorado River Basin into drainages to both the north and east. It may be found on a variety of substrates, including mud, mud and gravel, gravel, and occasionally sand. It is also comfortable living in a variety of water sources, having been documented in both small streams and large rivers, clear and murky waters, shallow or deep waters, and in still to swiftly moving waters (Cummings and Mayer 1992:120; Howells et al. 1996:75-76; Parmalee and Bogan 1998:149).

Potamilus purpuratus (Bleufer) is found from the Gulf Coast drainages, including the Guadalupe River Basin, into systems to the north and east. Documented through central and east Texas in both small and large streams and rivers, this species prefers quiet pools or 
In:

\section{$\stackrel{0}{=}$}

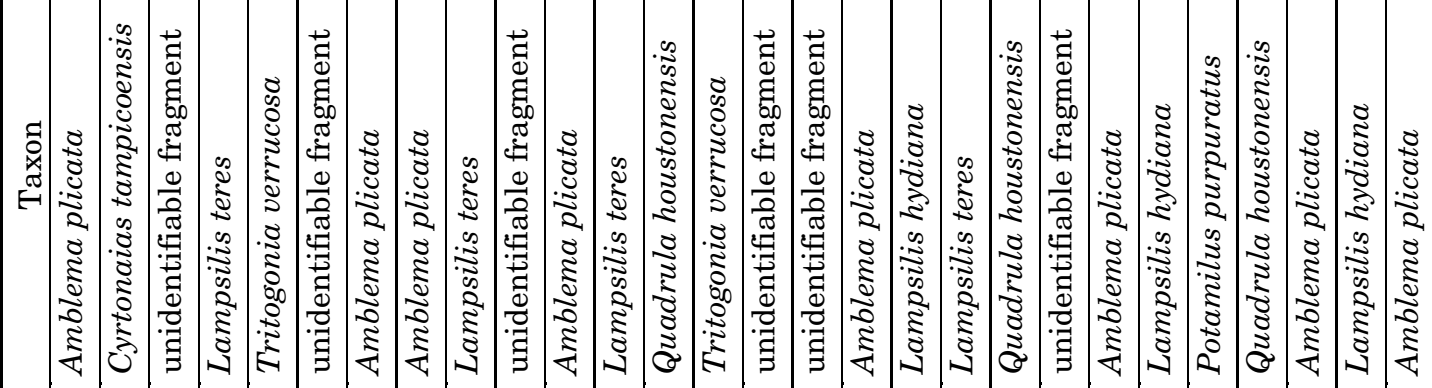

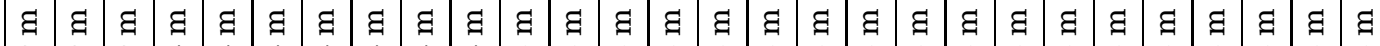

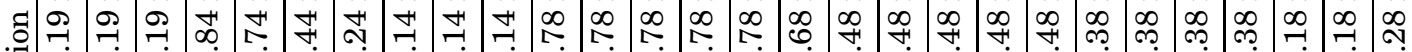
மூ

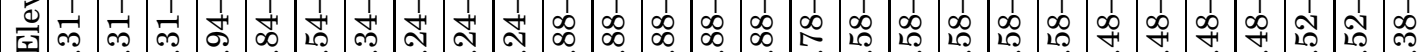

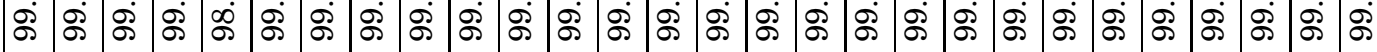

孛

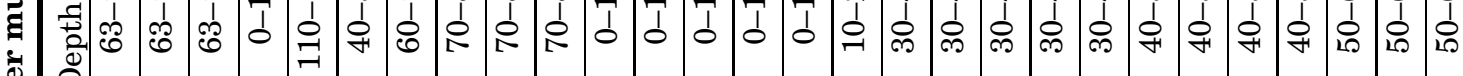
$\stackrel{8}{\circ}$

娄

|

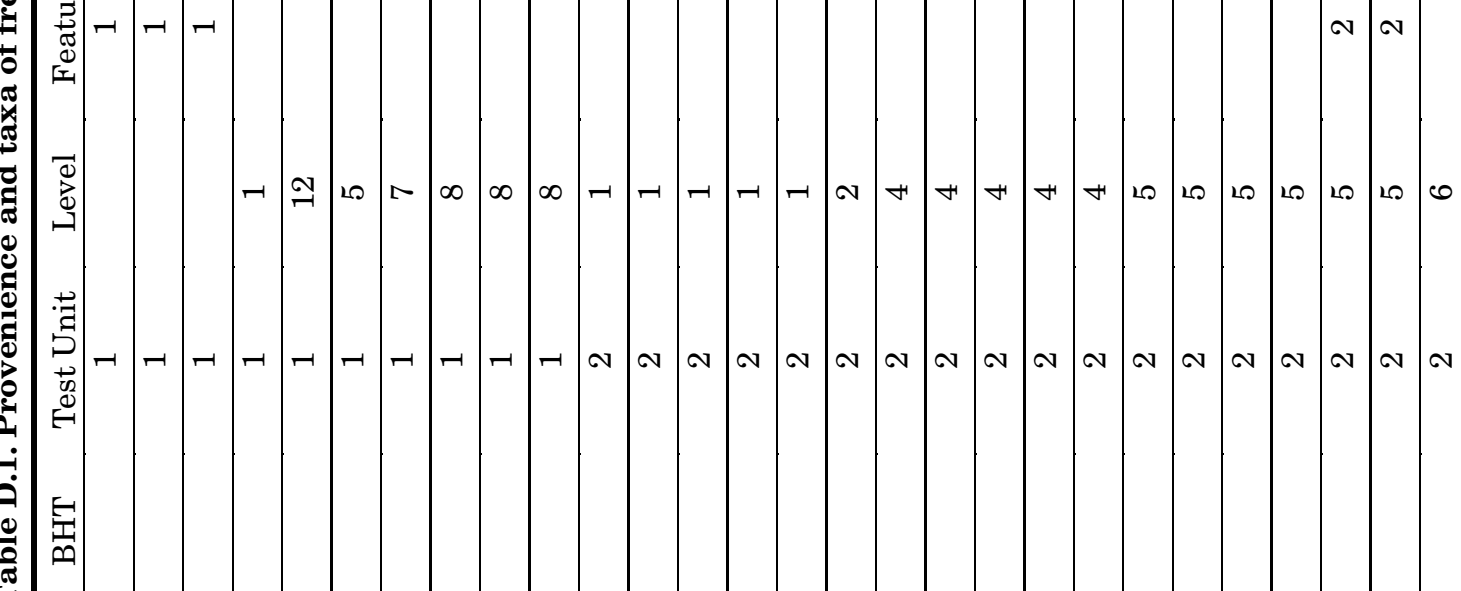




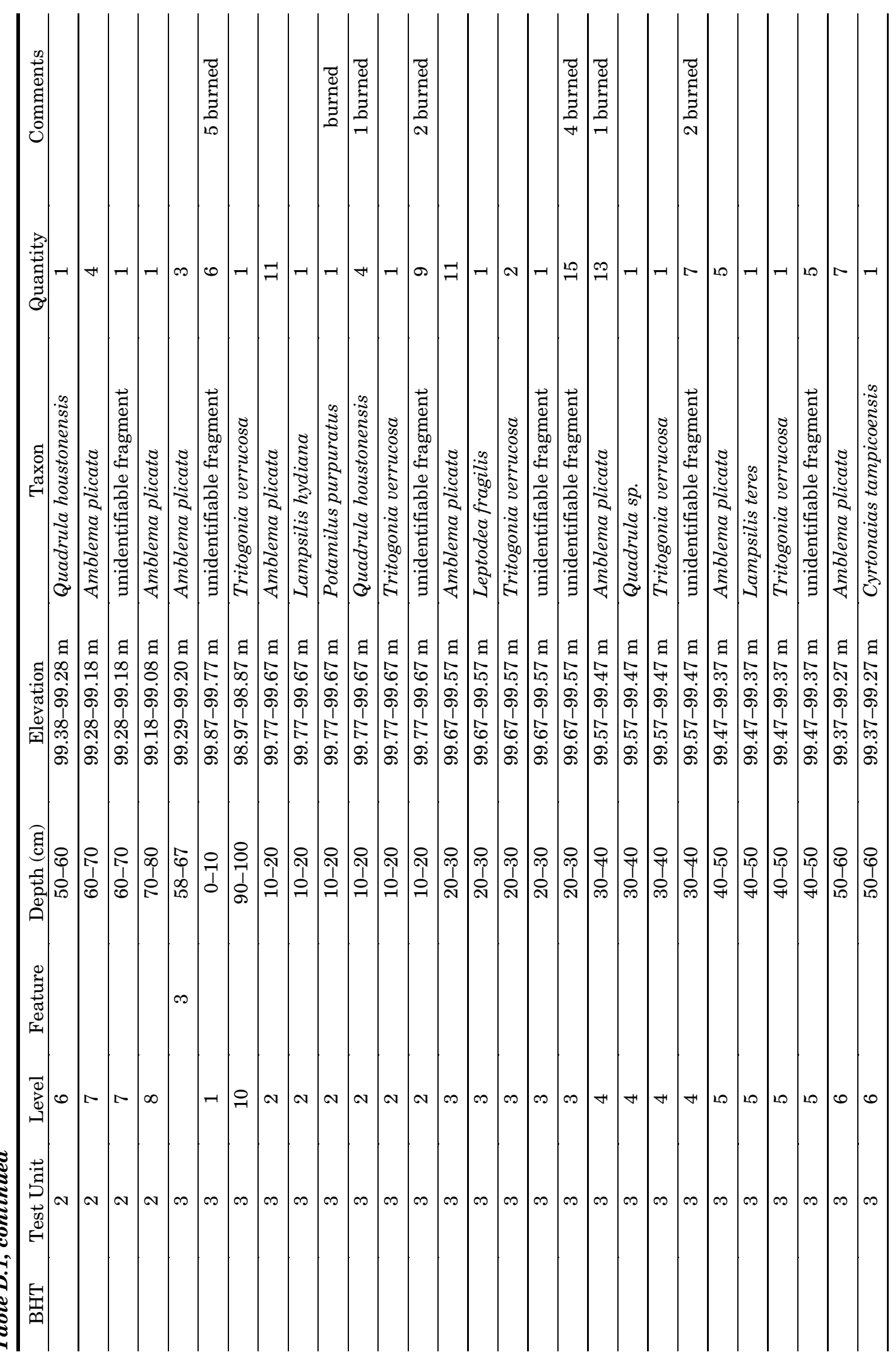




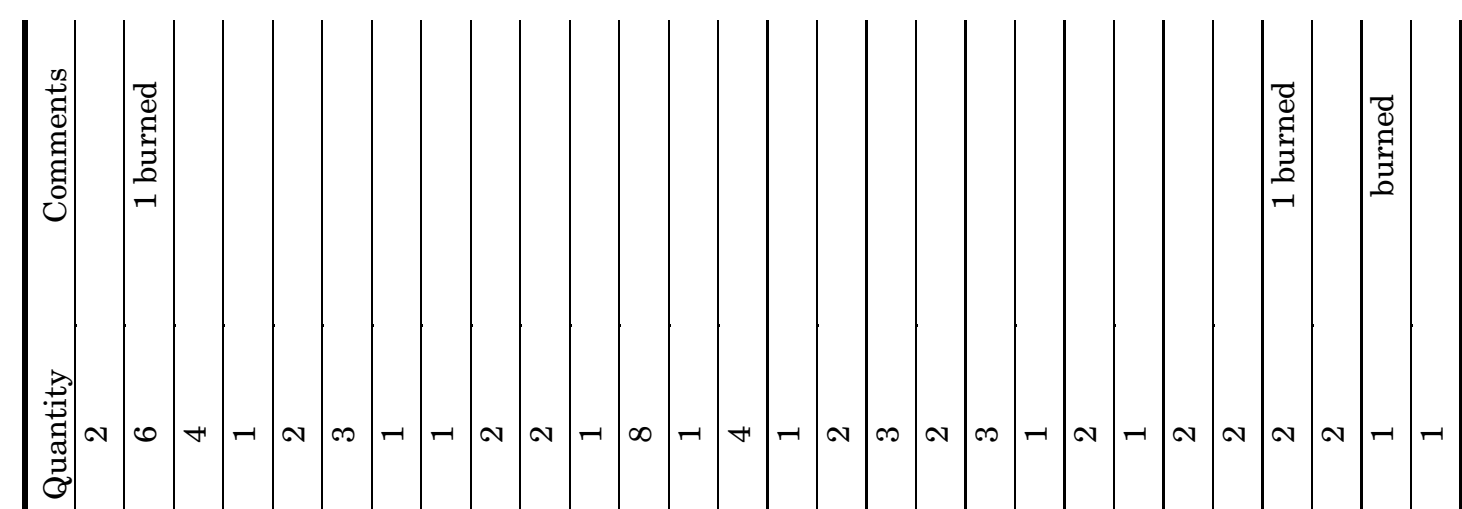

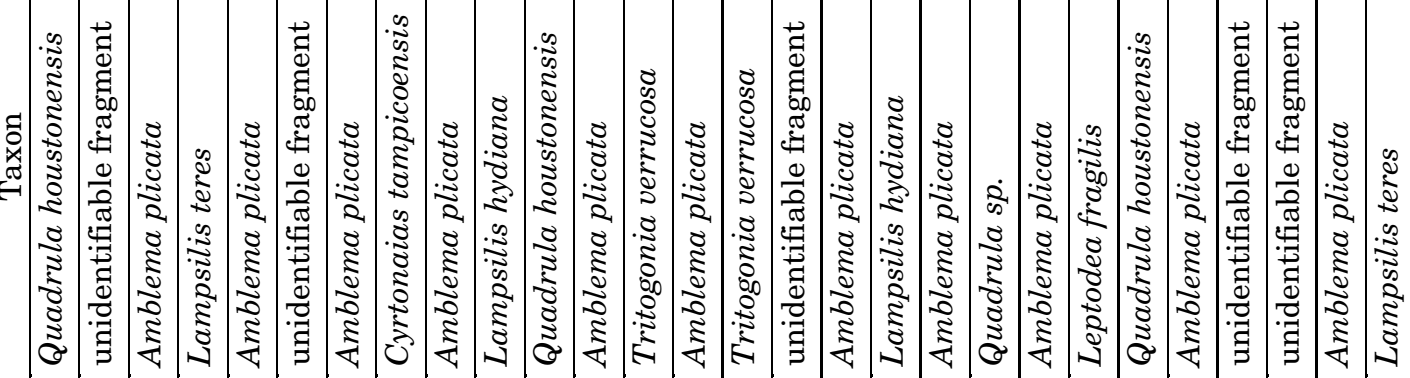
द द व

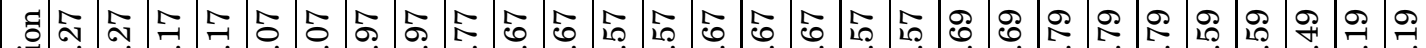

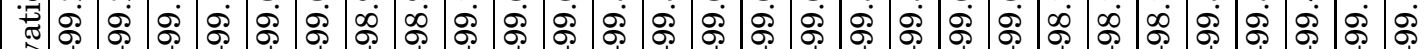

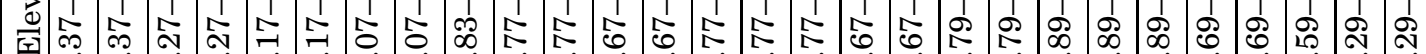

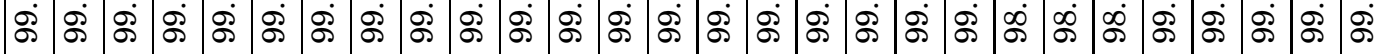

द્व્રે $\stackrel{\square}{\circ}$

荥

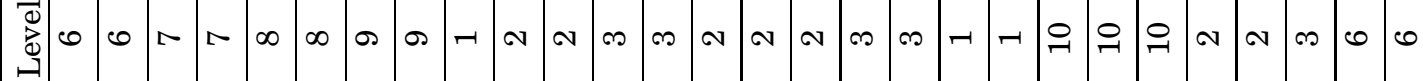

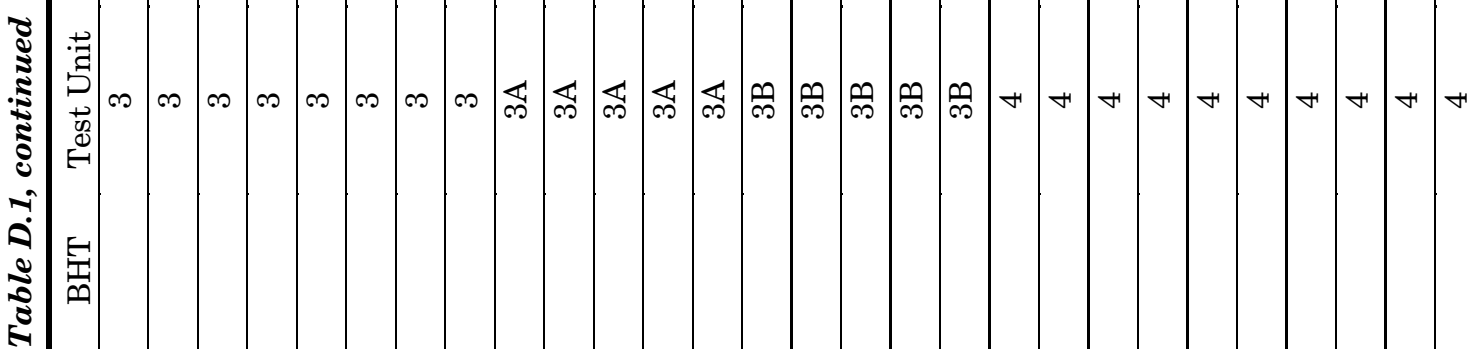




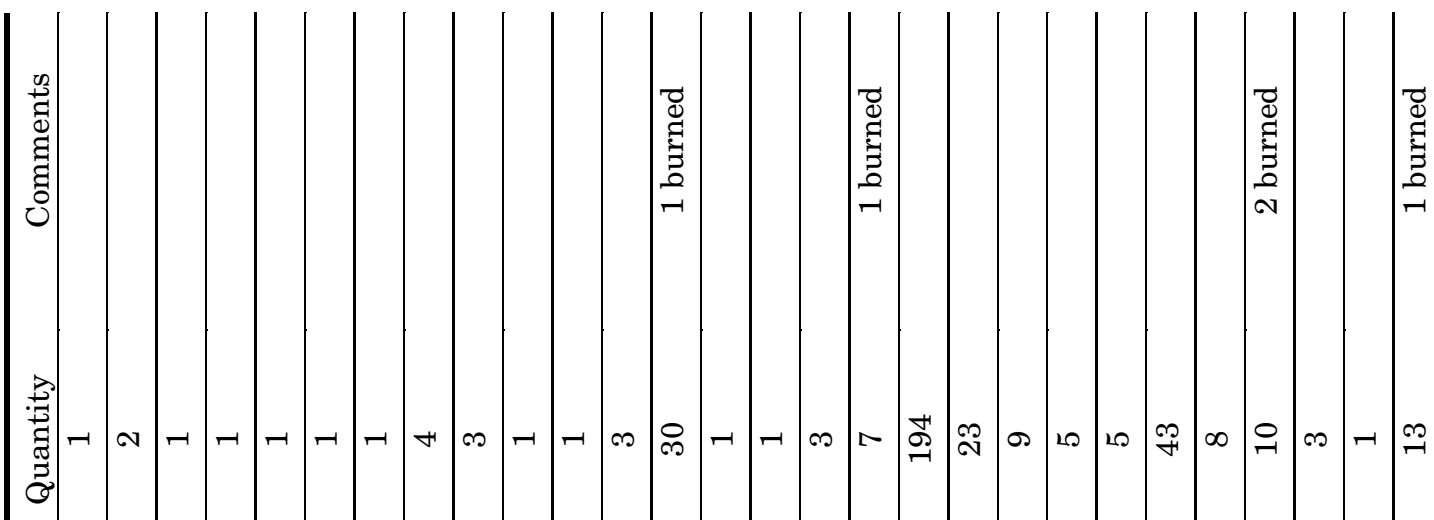

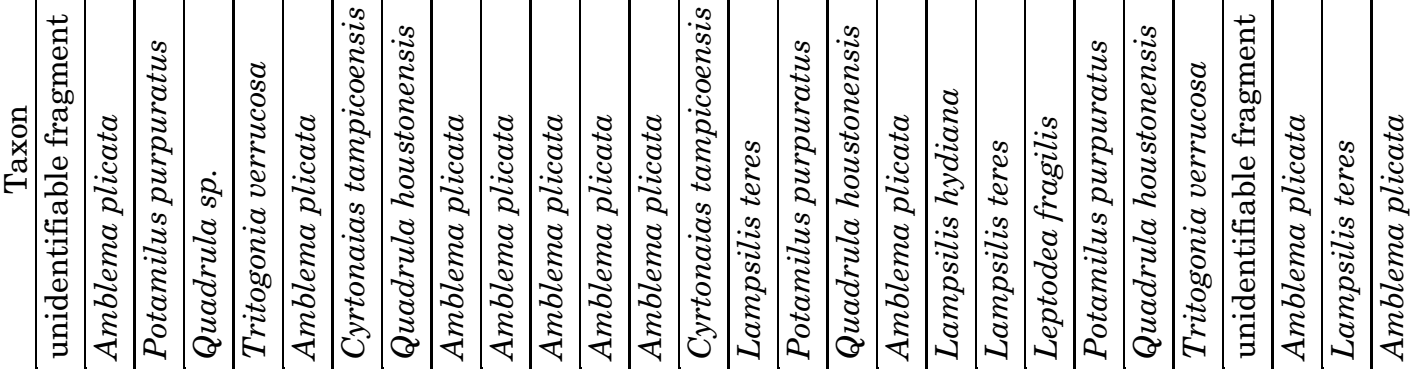

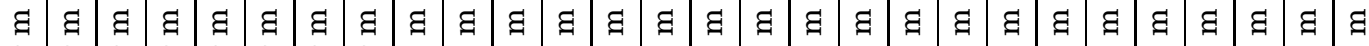
. نூ

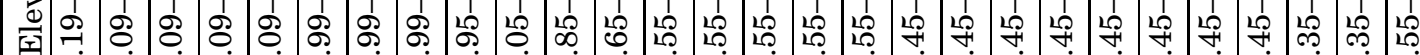

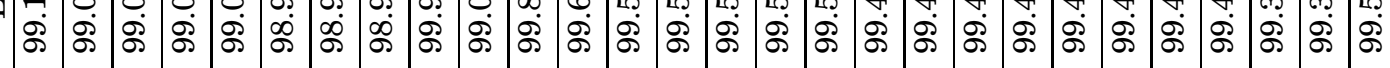

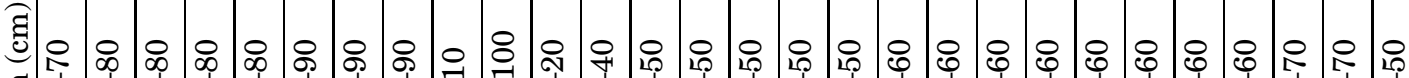

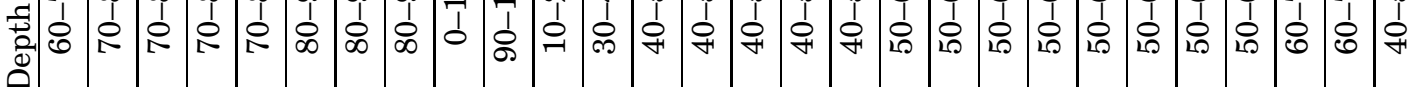

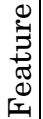

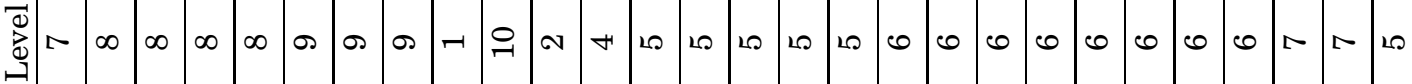

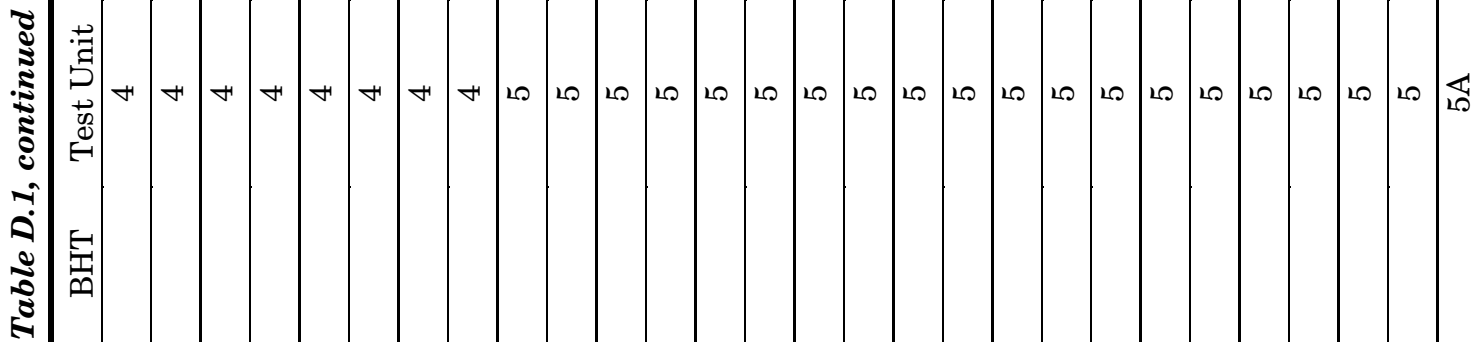




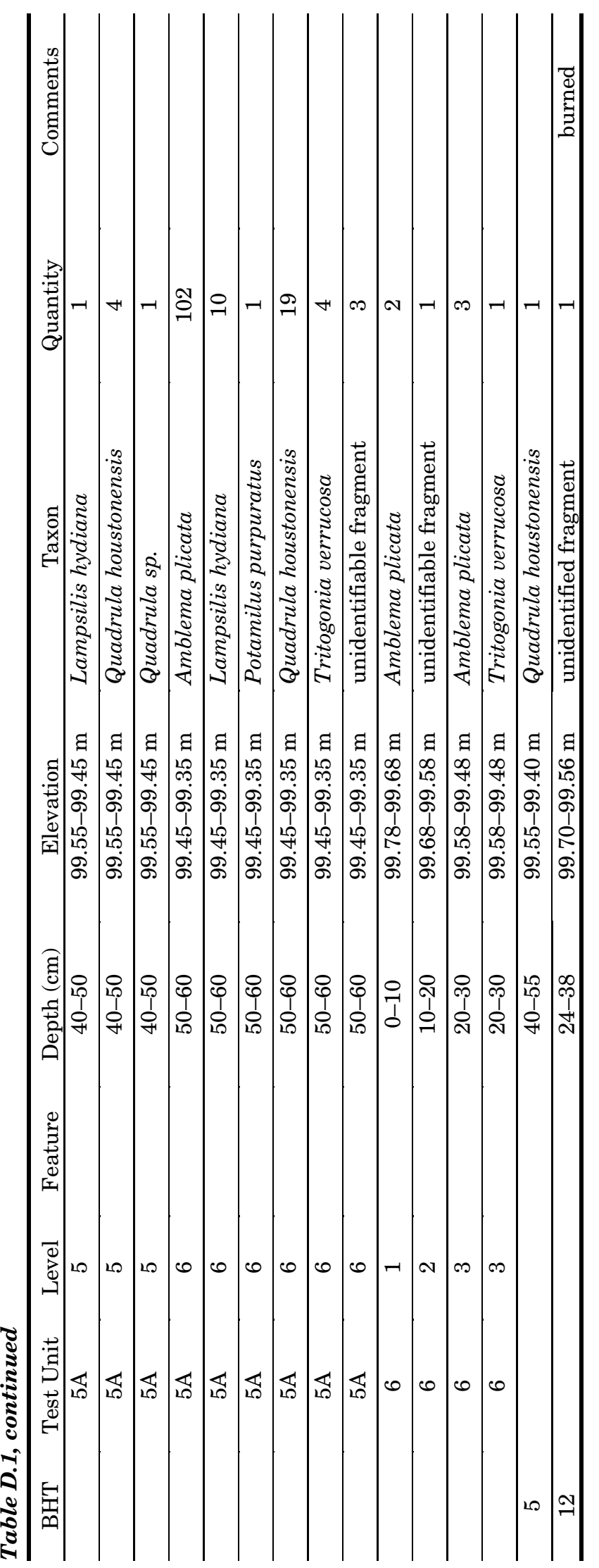


deepwater streams with slow-moving waters. Found at depths of up to three feet, it favors stable substrates such as mud or mud and gravel (Howells et al. 1996:101; Parmalee and Bogan 1998:201).

Quadrula houstonensis (Smooth Pimpleback) has been documented in the Colorado, Brazos, and San Jacinto drainage basins. This species is typically found on substrates composed of mixed mud, sand, and fine gravel
(Howells et al. 1996:112-113).

Tritogonia verrucosa (Pistolgrip) is documented as occurring in the Rio Grande, Guadalupe, Colorado, and Brazos river systems (Howells et al. 1996:127). This species prefers substrates made up of sand, coarse gravels, or mud, and has been found in medium-sized to large rivers at depths ranging from 1 to 20 feet (Cummings and Mayer 1992:26; Howells et al. 1996:128; Parmalee and Bogan 1998:235). 


\section{REFERENCES CITED}

Cummings, Kevin S., and Christine A. Mayer

1992 Field Guide to Freshwater Mussels of the Midwest. Illinois Natural History Survey, Manual 5. Champaign, Illinois.

Howells, Robert G., Raymond W. Neck, and Harold D. Murray

1996 Freshwater Mussels of Texas. Texas Parks and Wildlife Department, Austin.

Howells, Robert G., Jennifer Neel-Hartman, and Stacy A. Wagner

2003 Freshwater Mussel Shell from 41MM340. In Data Recovery Excavations at 41MM340,
A Late Archaic Site Along Little River in Milam County, Texas, by Richard B. Mahoney, Steve A. Tomka, Raymond P. Mauldin, Harry J. Shafer, Lee C. Nordt, Russell D. Greaves, and Rebecca R. Galdeano. Archaeological Survey Report No. 340. Center for Archaeological Research, The University of Texas at San Antonio.

Parmalee, Paul W., and Arthur E. Bogan

1998 The Freshwater Mussels of Tennessee. The University of Tennessee Press, Knoxville. 